\title{
Republic of the Marshall Islands Energy Project Development Options and Technical Assessment (2013)
}

Misty Dawn Conrad, Dan Olis, J. Erik Ness \& Sean Esterly

Sponsored by the Department of the Interior Office of Insular Affairs

September 2015

Produced under direction of the U.S. Department of the Interior Office of Insular Affairs by the National Renewable Energy Laboratory (NREL) under Interagency Agreement IAG-10-1773 and Task No. WFF41010. 


\section{ACKNOWLEDGMENTS}

The National Renewable Energy Laboratory (NREL) thanks the U.S. Department of the Interior's Office of Insular Affairs (OIA) for providing funding for this effort. In particular, NREL would like to thank OIA Acting Assistant Secretary Eileen Sobeck and Director Nikolao Pula for their vision and leadership in moving the energy planning and transformation process forward in the Pacific region.

NREL would like to acknowledge the valuable assistance of OIA staff: Angela Williams, Mark Brown, Joe McDermott, Jennifer Feng, and Charlene Leizear.

\section{NOTICE}

This manuscript has been authored by employees of the Alliance for Sustainable Energy, LLC ("Alliance") under Contract No. DE-AC36-08GO28308 with the U.S. Department of Energy ("DOE").

This report was prepared as an account of work sponsored by an agency of the United States government. Neither the United States government nor any agency thereof, nor any of their employees, makes any warranty, express or implied, or assumes any legal liability or responsibility for the accuracy, completeness, or usefulness of any information, apparatus, product, or process disclosed, or represents that its use would not infringe privately owned rights. Reference herein to any specific commercial product, process, or service by trade name, trademark, manufacturer, or otherwise does not necessarily constitute or imply its endorsement, recommendation, or favoring by the United States government or any agency thereof. The views and opinions of authors expressed herein do not necessarily state or reflect those of the United States government or any agency thereof. 


\section{Executive Summary}

The advancement of renewable energy and energy efficient technologies continues to be fluid. There are many technical opportunities and strategies that can be utilized to guide communities to deploy costeffective commercial alternative energy options; however, to achieve aggressive economic, environmental, and security goals, it requires a comprehensive, integrated approach.

This document reports the initial findings of an energy assessment that was conducted for the Republic of the Marshall Islands (RMI). It analyzes the technical opportunity of alternative energy technologies, compares these results to the RMI's National Energy Policy and Energy Plan (NEPEAP), and then identifies priority projects and next steps to implement that support the realization of these goals and objectives.

The body of this work was prepared for the U.S. Department of the Interior Office of Insular Affairs to provide technical assistance and support the RMI's fossil fuel reduction goals. This foundational document serves as a springboard toward the implementation of priority actions.

A sustainable future can be realized in island communities, such as the RMI, by taking advantage of cleaner fuels; secure resources; renewable and energy efficient technologies; and effective energy policy, codes, and standards. By applying the analyses, assessments, and planning, the next major step in the energy transformation process for the RMI is implementation. Accomplishing this requires many smaller steps outlined within this document, including the highest priority projects and the detailed actions involved in successful implementation.

The following figure represents identified priority actions, current RMI policy, standards, and projects alongside a snapshot of the RMI's power sector. 


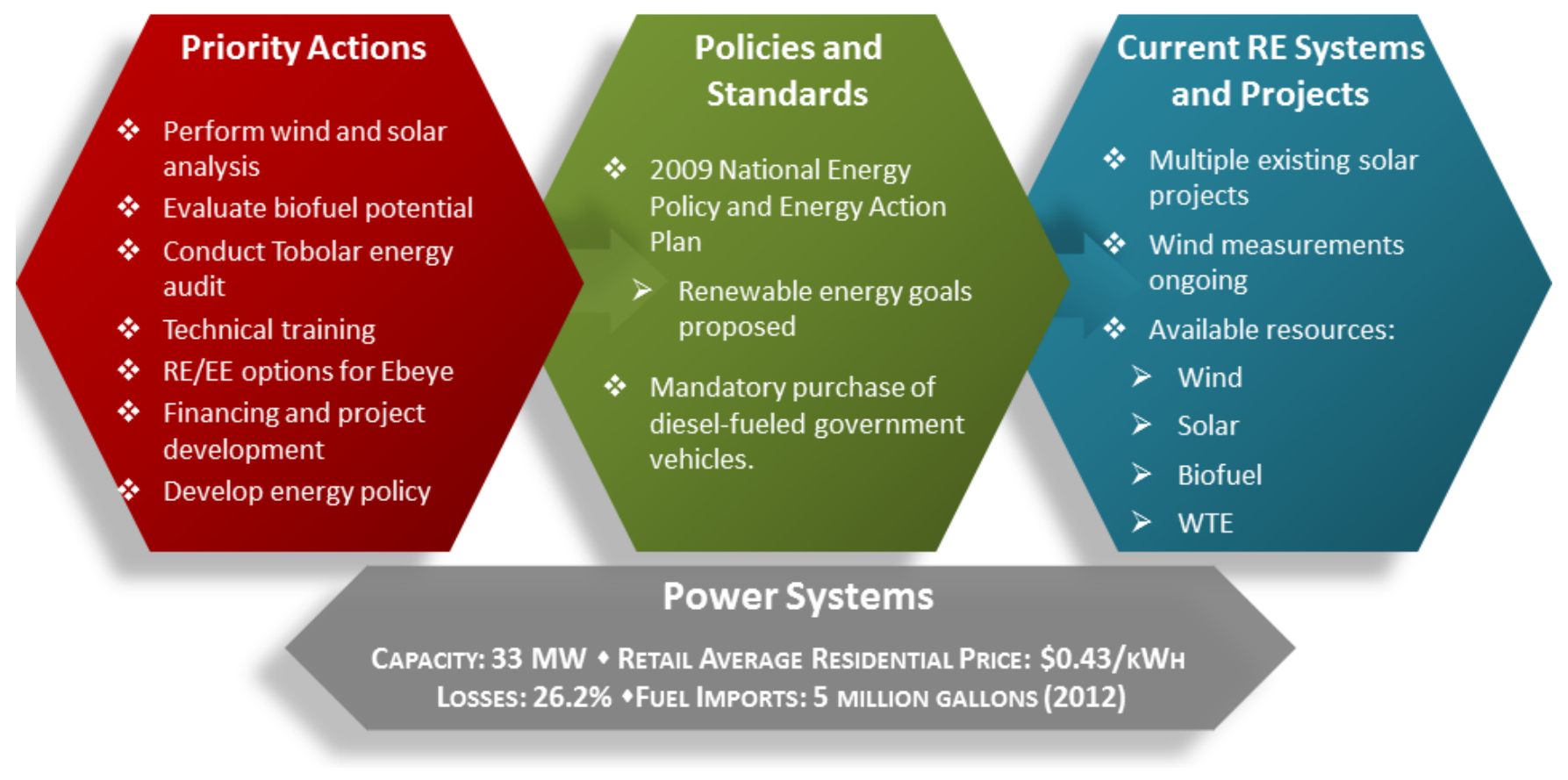

Figure ES-1. RMI energy synopsis 


\section{List of Acronyms and Abbreviations}

$\mathrm{AD} \quad$ anaerobic digestion

ADB Asian Development Bank

ADMIRE Action for Development of Marshall Islands Renewable Energies

AusAID Australian Agency for International Development

BAU business as usual

BOE barrels of oil equivalent

Btu British thermal unit

CNO coconut oil

DC direct current

DOD U.S. Department of Defense

DOI U.S. Department of the Interior

EDF $\quad$ European Development Fund

EE energy efficiency

EPPSO Economic Policy, Planning, and Statistics Office

FY fiscal year

GAO U.S. Government Accountability Office

GDP gross domestic product

GEF Global Environment Facility

HHV higher heating value

IRENA International Renewable Energy Agency

JICA Japan International Cooperation Agency

KAJUR Kwajalein Atoll Joint Utilities Resources

$\mathrm{kV} \quad$ kilovolt

kVAR kilovolt-amperes reactive

$\mathrm{kW} \quad$ kilowatt

kWh kilowatt-hour

LFGTE landfill-gas-to-energy 


\begin{tabular}{|c|c|}
\hline $\mathrm{m}$ & meter(s) \\
\hline MEC & Marshalls Energy Company \\
\hline MRD & Ministry of Resources and Development \\
\hline MRF & material recovery facility \\
\hline MSW & municipal solid waste \\
\hline MVA & megavolt-ampere \\
\hline MW & megawatt \\
\hline NEPEAP & National Energy Policy and Energy Action Plan \\
\hline $\mathrm{NGO}$ & nongovernmental organization \\
\hline NREL & National Renewable Energy Laboratory \\
\hline ODA & official development assistance \\
\hline OIA & Office of Insular Affairs \\
\hline OTEC & ocean thermal energy conversion \\
\hline PV & photovoltaics \\
\hline $\mathrm{RE}$ & renewable energy \\
\hline RET & renewable energy technologies \\
\hline RFP & request for proposals \\
\hline RMI & Republic of the Marshall Islands \\
\hline RUS & Rural Utilities Service \\
\hline SWH & solar water heating \\
\hline UNDP & United Nations Development Programme \\
\hline USDA & United States Department of Agriculture \\
\hline $\mathrm{W}_{\mathrm{p}}$ & watts peak \\
\hline $\mathrm{W}_{\text {th }}$ & watts thermal \\
\hline WTE & waste-to-energy \\
\hline
\end{tabular}




\section{Table of Contents}

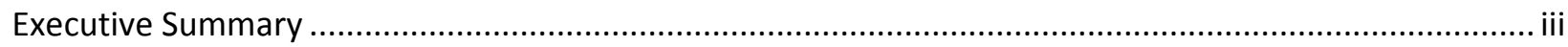

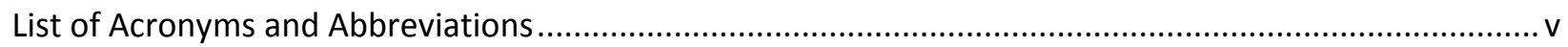

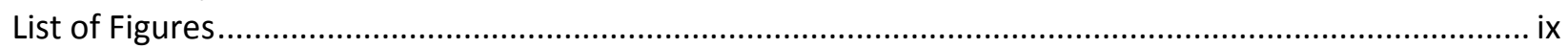

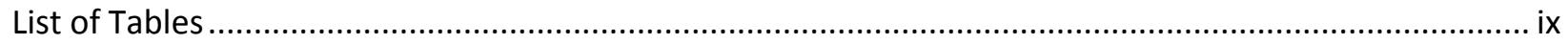

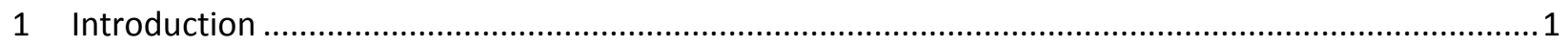

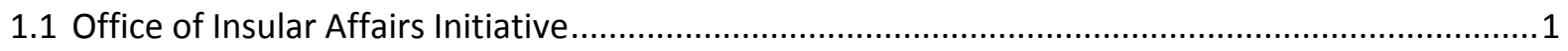

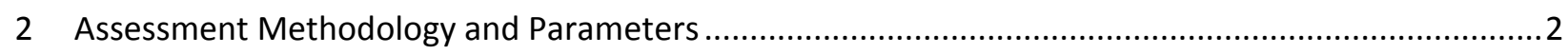

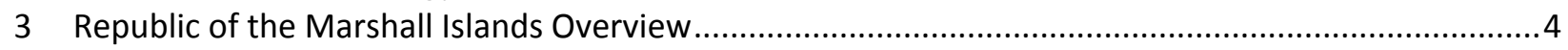

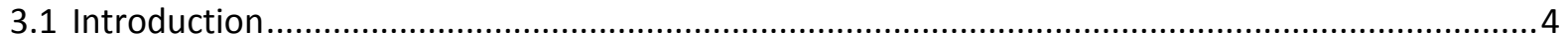

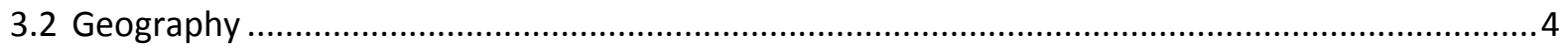

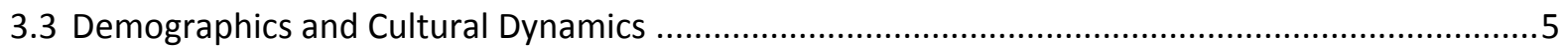

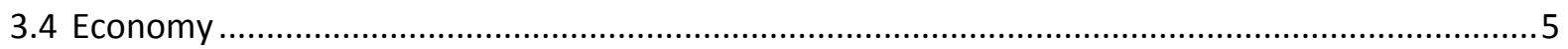

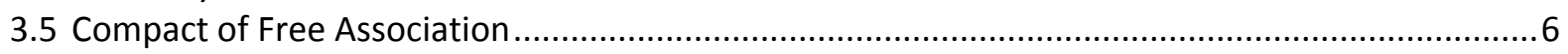

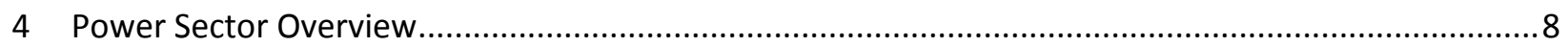

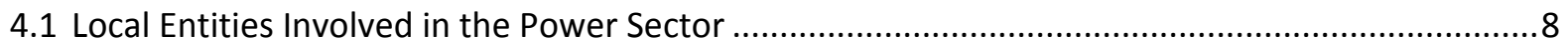

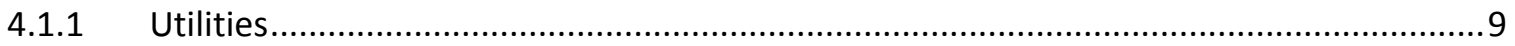

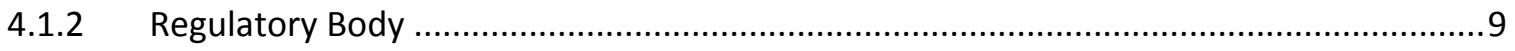

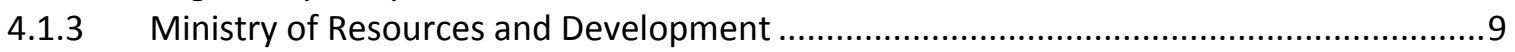

4.1.4 Economic Policy, Planning, and Statistics Office ....................................................... 10

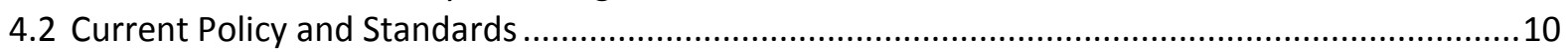

4.3 National Energy Policy and Energy Action Plan................................................................11

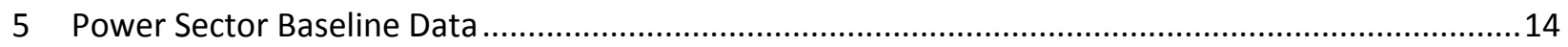

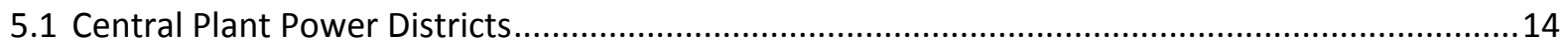

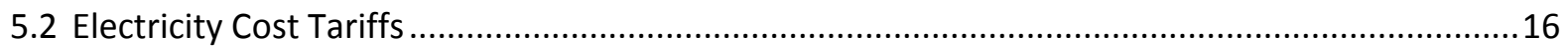

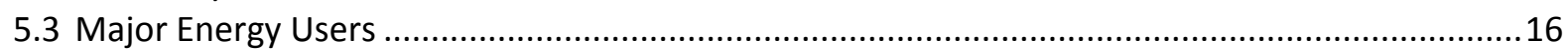

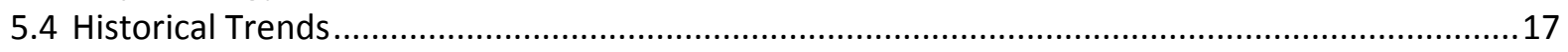

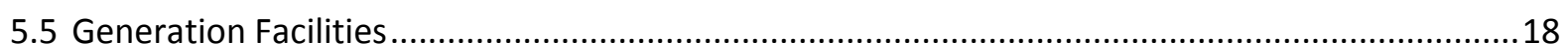

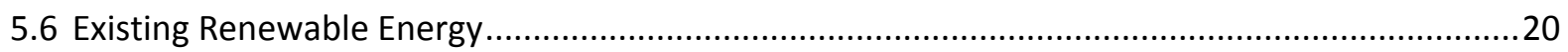

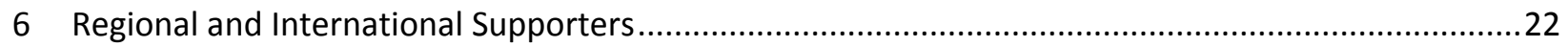

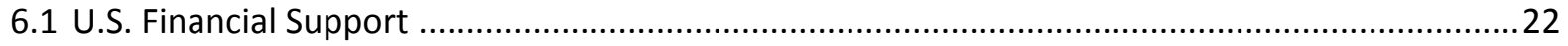

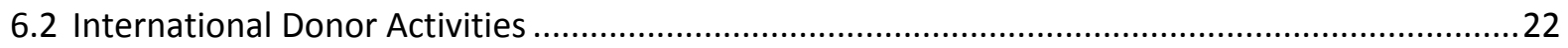

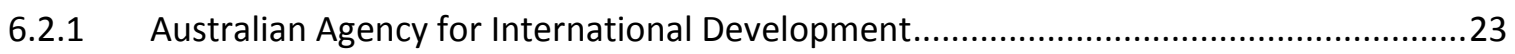

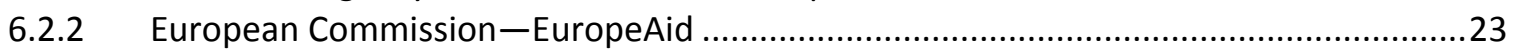

6.2.3 United Nations Development Programme ................................................................24

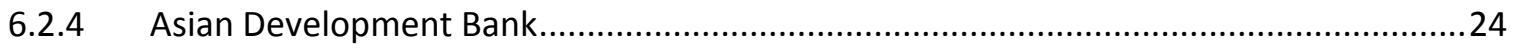

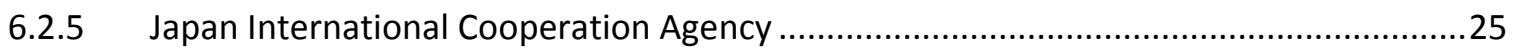

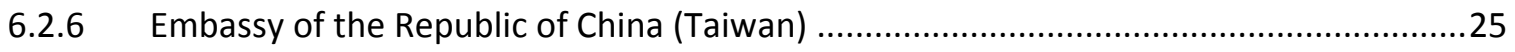

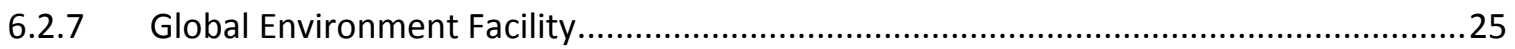

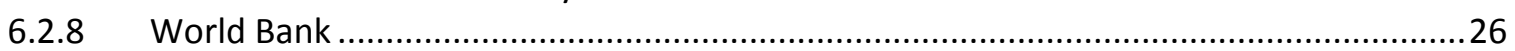

7 Energy Efficiency and Renewable Energy Opportunities.............................................................28

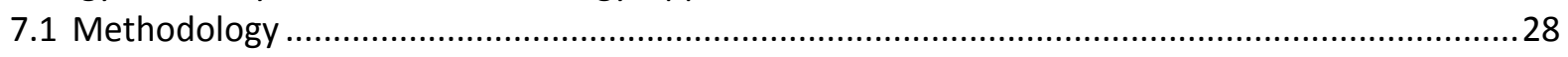

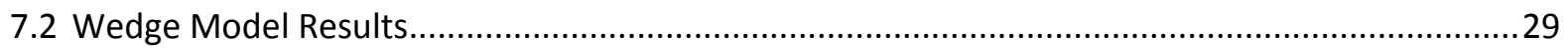

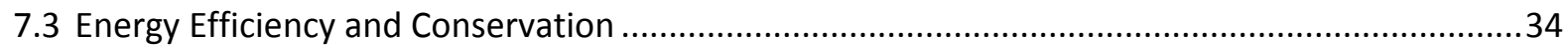

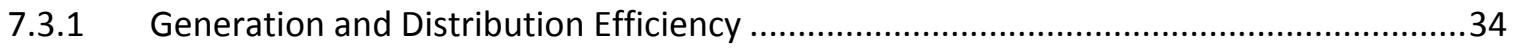

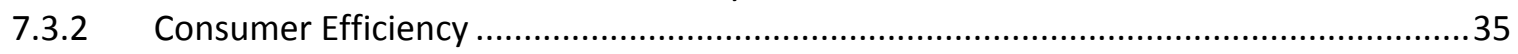

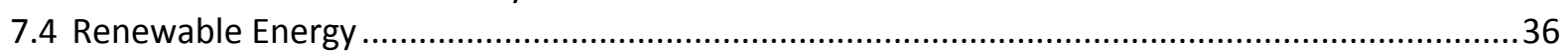

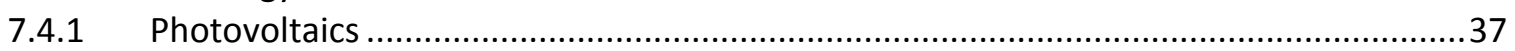

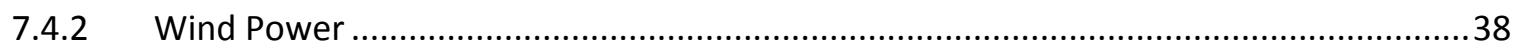

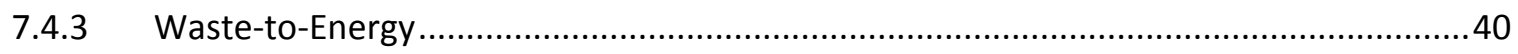

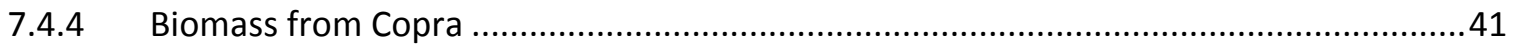

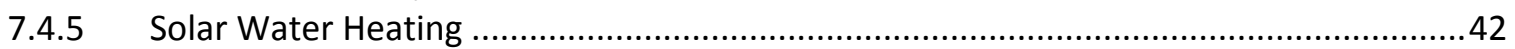




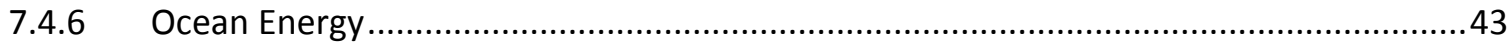

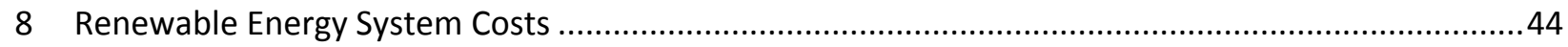

8.1 Treatment of Biomass and Waste-to-Energy Technologies .....................................................4

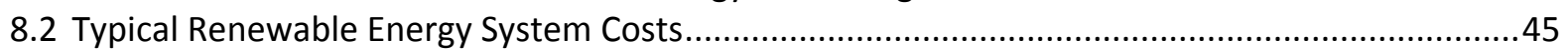

8.3 Cost of Electricity from Renewable Power Systems on Pacific Islands ........................................46

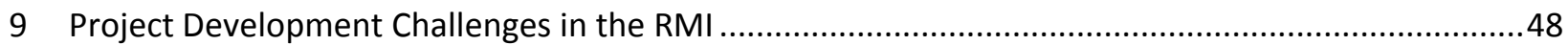

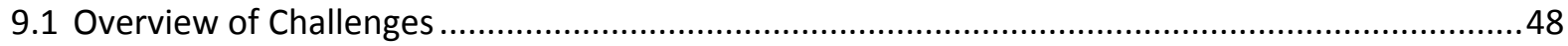

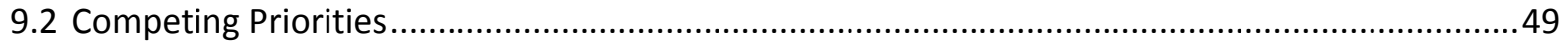

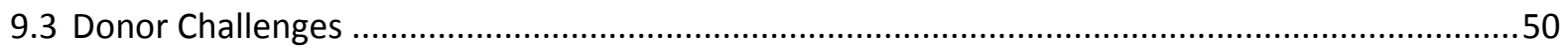

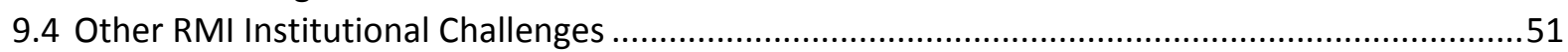

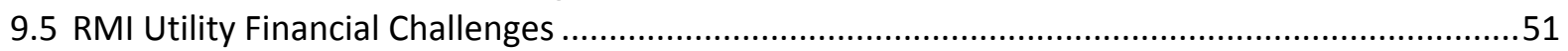

10 The Need for Energy-Related Policies and a Standardized Project Development Process ..................52

10.1 Recommendations for Energy-Related Procedures .................................................................53

10.1.1 Develop Multiple Financial Mechanisms and Opportunities ......................................53

10.1.2 Standardize and Optimize the Project Development Process......................................53

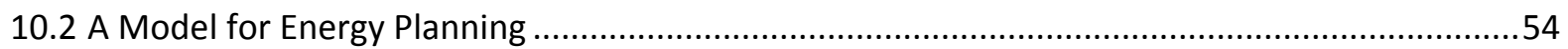

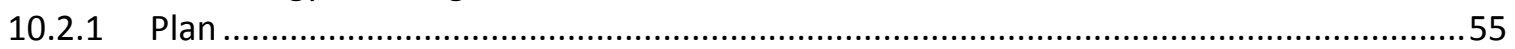

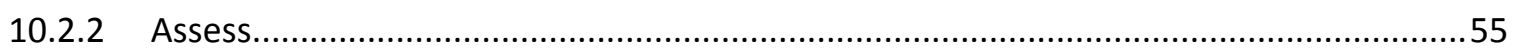

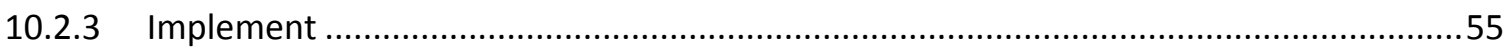

10.3 A Standardized Framework for Project Development...........................................................56

10.3.1 Establish Fundamental Project Parameters Before Commencing Development............56

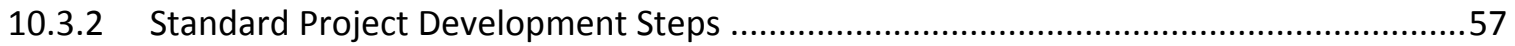

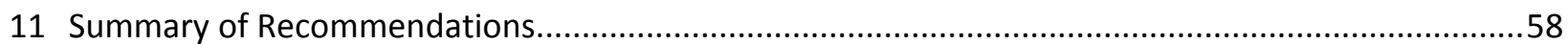

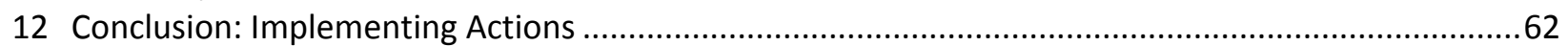

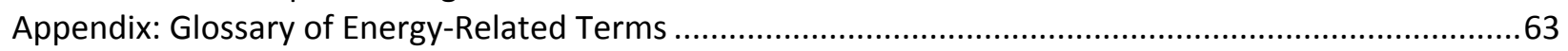




\section{List of Figures}

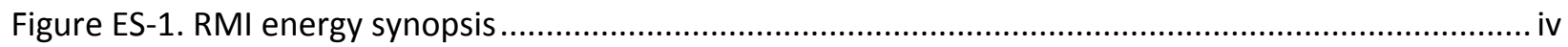

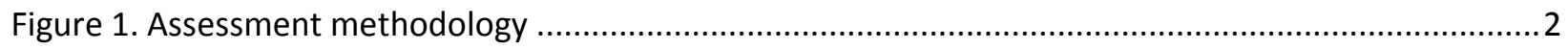

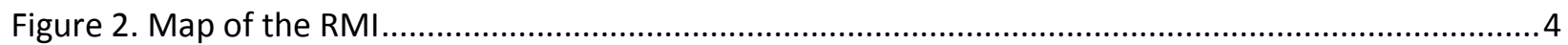

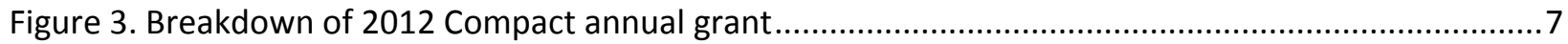

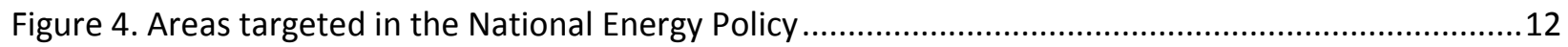

Figure 5. Downward trend in fuel consumption at Majuro power plants .............................................18

Figure 6. International donor funds (excluding the Compact) ............................................................27

Figure 7. International donor funds (including the Compact) .............................................................2

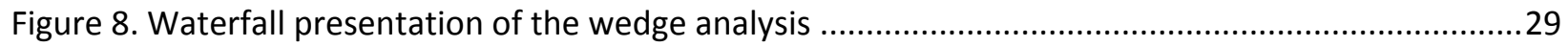

Figure 9. The RMI electricity sector in 2032 relative to the 2012 baseline ............................................30

Figure 10. Analysis model scenario wedges from 2012 to 2032 ........................................................31

Figure 11. Analysis model power generation profile from 2012 to 2032 ..............................................32

Figure 12. Analysis model renewable energy profiles from 2012 to 2032 (the vertical axis scale is

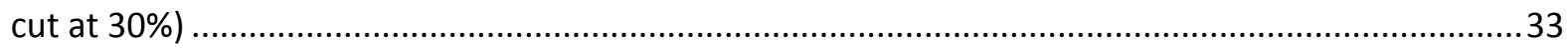

Figure 13. Energy efficiency reductions attributed to improvements in demand and supply from

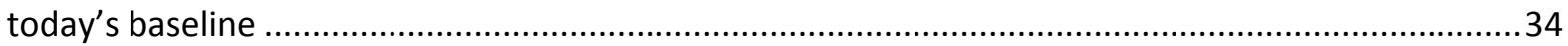

Figure 14. Contribution of each renewable energy technology to generation profile in 2032 .................37

Figure 15. Levelized cost of electricity from renewable power systems on Pacific islands .......................47

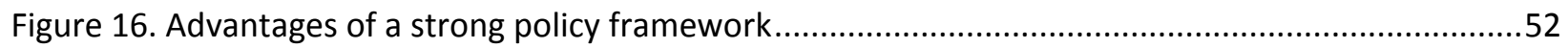

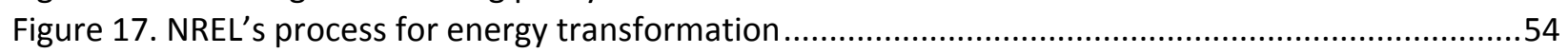

Figure 18. The strategic plan and the steps involved in the process ....................................................56

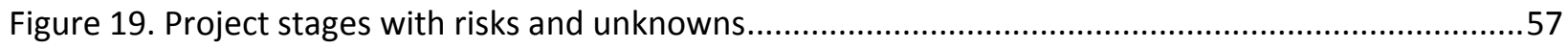

Figure 20. Energy projects identified in the RMI NEPEAP and by NREL's assessment team ....................62

\section{List of Tables}

Table 1. RMI 2011 population, land area, and electrification by atoll and island....................................15

Table 2. Generation data for Majuro, Ebeye, and Jaluit for 2012 ......................................................16

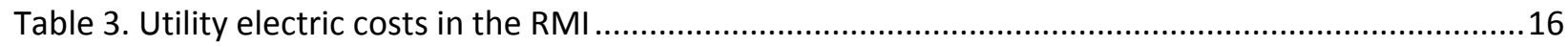

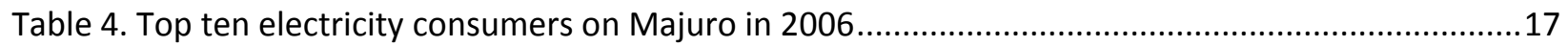

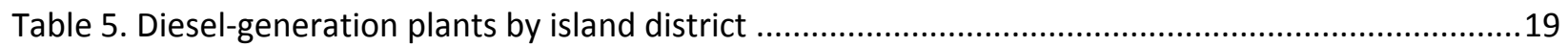

Table 6. Power plant heat rates for Majuro, Ebeye, and Jaluit for 2012 ...............................................19

Table 7. Partial list of existing renewable energy systems in RMI .......................................................20

Table 8. Generation and distribution system efficiency benchmarks and assumed improvements ..........35

Table 9. Electricity usage and end use efficiency gains by sector assumed in the analysis .......................36

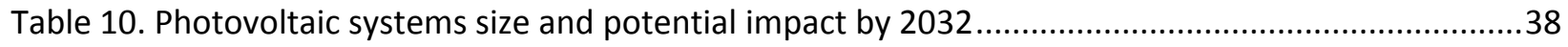

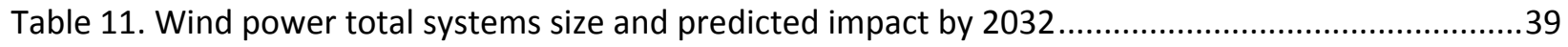

Table 12. Waste-to-energy system size and predicted impact by 2032 ...................................................41

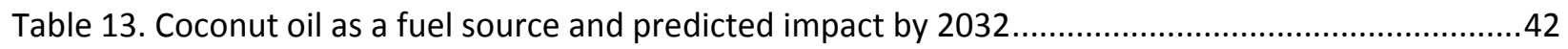

Table 14. Solar water heating total installation size and predicted impact by 2032 ...............................43

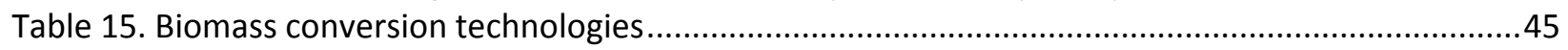

Table 16. Estimated cost of energy and installation costs for renewable energy systems........................46

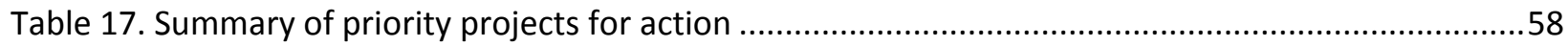




\section{Introduction}

Island communities face great challenges in achieving reliable, affordable, and secure energy for power and transportation needs. Most islands are relatively small and geographically remote, wrestling for decades with their dependence on fossil fuels and the burden of high oil prices. Imported fuel is typically very expensive. The expense, volatility in price, and potential for disruption in supply of fuel has a significant effect on island economies. While the landscape of island energy planning and development has become more at the forefront of discussion, islands continue to struggle with various challenges. Most island communities have a relative abundance of renewable energy resources, but still remain highly dependent on imported fossil fuels to meet their energy needs. Although islands are faced with unique challenges, there are significant opportunities to build momentum and generate considerable sustainable results.

\subsection{Office of Insular Affairs Initiative}

The US Department of the Interior (DOI) Office of Insular Affairs (OIA) has partnered with the U.S. Department of Energy's National Renewable Energy Laboratory (NREL) to engage the Republic of the Marshall Islands (RMI) by offering assistance in an effort to address technical and economic hurdles to deploying cost-effective energy efficiency and renewable energy technologies on islanded systems. Due to unpredictable and fluctuating energy prices, security concerns, economic development, natural disasters, and climate change, many island communities are focusing their attention on developing energy alternatives to address these challenges. Energy security is fundamental to a sustainable economic future. With the overarching threat of climate change, island communities face a greater degree of urgency for relief.

The primary purpose of this initiative is to support the RMI's energy goals through a variety of technical assistance projects performed by NREL. In support of OIA's initiative, NREL will assist the RMI with their efforts to reduce energy costs and diversify from near total dependence on petroleum-based fuels. This support effort concentrates on an integrated solution and approach - first identifying what has been done before so as not to replicate efforts, then analyzing current endeavors, conducting a technical assessment, and scoping and assisting in developing strategies that will accelerate implementation of alternative energy solutions. Using this comprehensive approach provides the catalyst to transform the way energy is used in the RMI by identifying opportunities, building partnerships, and establishing a foundation for the implementation of energy efficiency and renewable energy technologies.

This report details initial scoping results and technical opportunity findings, and outlines implementation strategies. Following the publication of this report, NREL will work with the appropriate RMI representatives on the identified next steps. 


\section{Assessment Methodology and Parameters}

NREL's initial technical assessment of renewable energy and energy efficiency options and strategies in the RMI include documentation of existing energy systems, data, resources, policies, institutions, demographics, and geography. Population distribution and physical geography impact energy production, distribution, and consumption, so understanding these issues are important.

Energy data collection and a review of previous studies allowed the assessment team to ascertain the current ("baseline") of energy generation and consumption in the RMI. It also provided the team with information on which energy policies, programs, or projects are currently in place, as well as understanding those that may have been attempted or implemented previously. The data collection process coincided with a site visit to interview stakeholders, survey the RMI's energy needs, and determine the options to be included in the assessment study. After the site visit, NREL staff analyzed the data and information, and opportunities were identified.

Figure 1 illustrates the major components of NREL's assessment methodology.

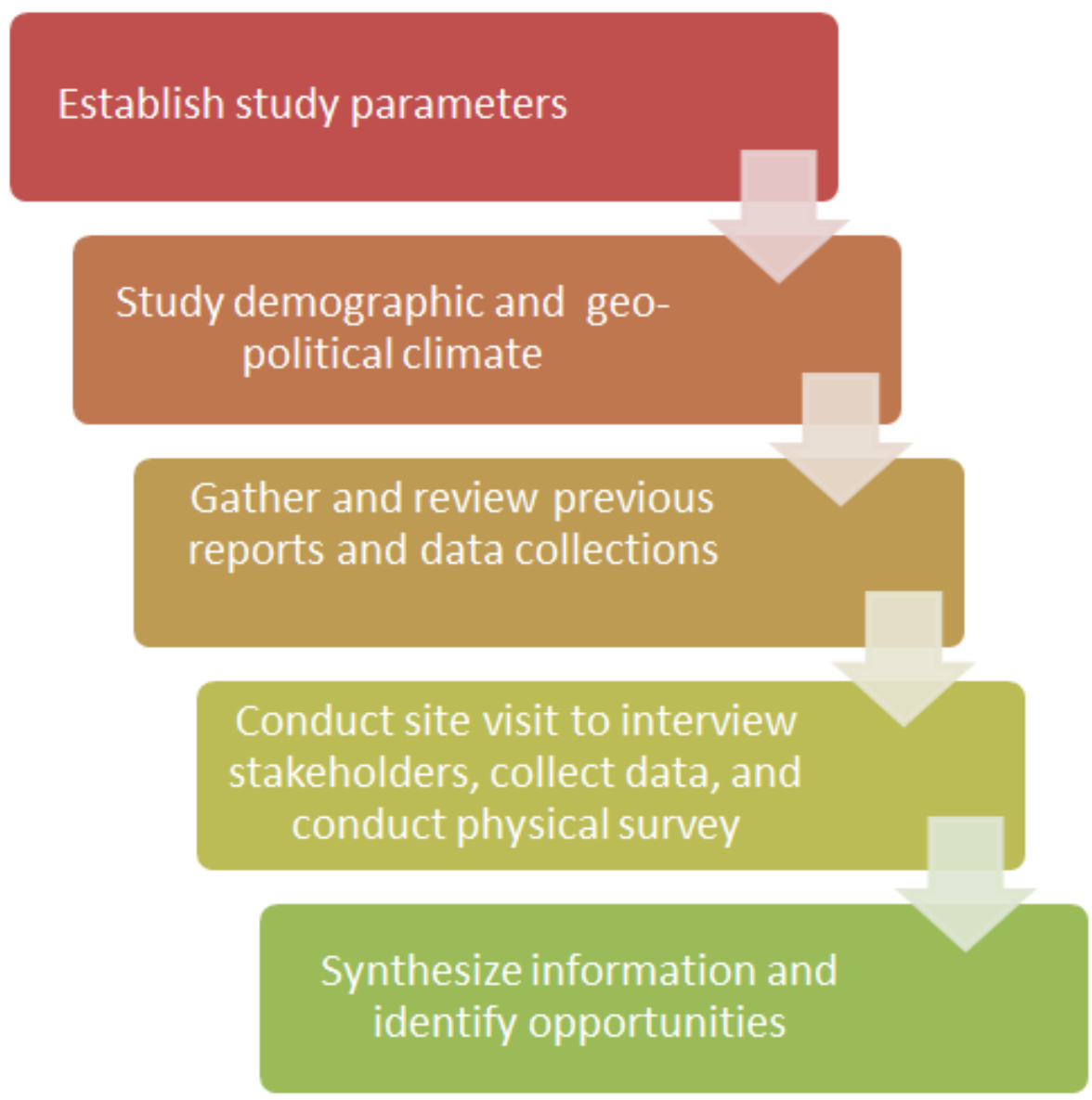

Figure 1. Assessment methodology 
There are many energy efficiency and renewable energy technologies on the market today. Included within this initial assessment's parameters are mature technologies that are commercially available. There are other technologies the RMI may decide to investigate for future study, but for the purposes of this document, technologies included have the following criteria:

- Commercially available

○ Tested and demonstrated

- Carry warranty

○ Service and parts available.

- Ready for immediate deployment

- Demonstrated to be a sound investment

- Financing available from private sector organizations.

Each technology has its own operational characteristics, initial installation and operating costs, implementation time horizon, and near- and long-term environmental impacts. Most power generation choices require a large investment that can impact a community for many years. For these reasons, the optimal choice of technologies should be identified through a process of strategic energy analysis (including technical, economic, financial, environmental, social, and policy evaluation) to help ensure the most appropriate choices are made for current and future generations of RMI residents.

Changes to the power generation sector are not the only option to address the RMI's energy challenges. Energy conservation and efficiency is a cost-effective method to potentially reduce the need for increased investment in electricity generation. The development and implementation of advanced diesel/renewable/storage microgrids for the outer atolls would also have economic and environmental benefits associated with reducing fuel shipping costs and potential risks associated with diesel fuel storage.

The assessment team evaluated commercial technologies, including energy conservation and efficiency, wind, solar (photovoltaic and water heating), biomass, waste-to-energy, and biodiesel produced from copra.

This assessment report discusses renewable energy and energy efficiency technology potential, as well as current barriers and opportunities. However, this evaluation is based on incomplete data on the energy needs and options in the RMI, so the margin of error in the assessment team's findings and conclusions is relatively high. Further investigation is needed to improve the quality of the data available to decisionmakers and to be able to quantify the impact of specific technologies, programs, and/or projects.

Environmental, regulatory, legislative, and financial considerations will also need to be addressed during the project implementation process. Technologies and markets are constantly changing and evolving; as a result, continual reevaluation of options and strategies is necessary. 


\section{Republic of the Marshall Islands Overview}

\subsection{Introduction}

The RMI is a small, independent island nation in the North Pacific Ocean, located about halfway between Hawaii and Australia (see Figure 2). The RMI maintains close association to the United States as a freely associated state through the Compact of Free Association (the Compact).

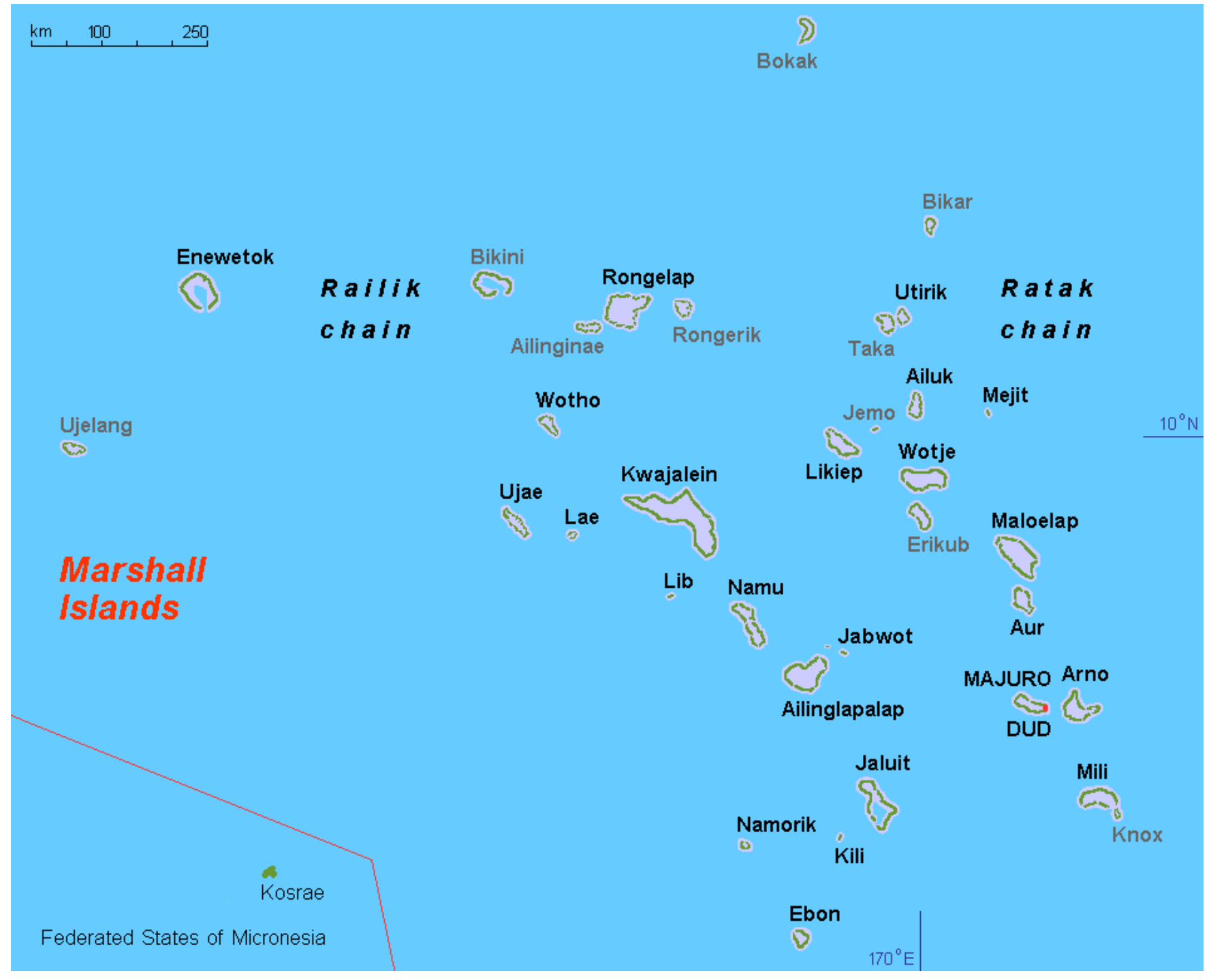

Figure 2. Map of the RMI

Source: Wikimedia Commons (http://commons.wikimedia.org/wiki/File:MH -map A.png)

\subsection{Geography}

The RMI is composed of 70 square miles of land (about the size of Washington, D.C.), and is dispersed over approximately 750,000 square miles of ocean in the northern Pacific. The land area consists of two archipelagic island chains made up of 29 atolls with many small islets and five single islands. The two archipelago island chains are known as the Ratak Chain and Ralik Chain, meaning sunrise and sunset.

The islands of Bikini and Enewetak are former U.S. nuclear test sites. The Kwajalein Atoll, famous as a World War II battleground, surrounds the world's largest lagoon and is used as a U.S. missile test range. The island city of Ebeye is the second largest settlement in the Marshall Islands, after the capital of Majuro, and one of the most densely populated locations in the Pacific. 
Sea level rise, an anticipated consequence of climate change, is likely to have a significant impact on this low-lying nation because all Marshallese live within several yards of any shoreline. The average elevation of the RMI is 2 meters (m) above sea level, while the highest point is 10 meters. ${ }^{1}$ A $0.8 \mathrm{~m}$ rise in sea level would flood over $60 \%$ of the RMI and impact remaining shorelines, vegetation, and agriculture, ${ }^{2}$ fisheries, ${ }^{3}$ and scarce freshwater resources. ${ }^{16}$

\subsection{Demographics and Cultural Dynamics}

The RMI has a population of 53,000 people. The Marshallese reside on approximately 24 municipalities including atolls and individual islands. Majuro, the capital city, is the most populated atoll with $52 \%$ of the country's population; 27,800 people live within the Majuro Atoll and 21\% (11,400 people) reside on Ebeye within the Kwajalein Atoll, which is approximately 250 miles northwest of Majuro. The next three most populous atolls are Arno (1,794 people), Jaluit (1,788 people), and Ailinglaplap (1,729 people). ${ }^{4}$

Cultural dynamics can often impact energy consumption. The RMI's population is $92.1 \%$ Marshallese, $5.9 \%$ mixed Marshallese, and 2\% non-Marshallese ethnicity. ${ }^{5}$ The official languages of the RMI are Marshallese, which is spoken by $98.2 \%$ of the population, and English. Other languages are spoken by $1.8 \%$ of the population. The net emigration rate on the RMI is five/1,000 people, with annual rates of outward migration averaging $1.7 \%$ since $2003 .^{6}$

Small and young children, ages $0-14$, continue to constitute the largest portion (40\%, or 21,263 people) of the Marshallese population, indicating RMI has very high birth rates, although this has come down from $43 \%$ and $51 \%$ as indicated by the 1999 and 1988 censuses, respectively. Of the portion of the population aged 25 and older, 28.6\% (6,317people) started high school but did not complete it. Literacy studies reveal that $90.6 \%$ of Marshallese aged five and older are literate. ${ }^{7}$

\subsection{Economy}

Per capita gross domestic product (GDP) of the Marshall Islands ranks fairly low at \$3,488 compared to the United States $(\$ 47,822)$ and the world average $(\$ 10,102) .{ }^{8}$ The International Monetary Fund estimates that in 2011, grants to RMI equaled $38.4 \%$ of the RMI's total \$170.7 million GDP. ${ }^{9}$

Approximately $44 \%$ of the workforce is employed by the public sector, including about $8 \%$ in stateowned enterprises. Nongovernment organizations (NGOs), foreign embassies, and the U.S. Army base at Kwajalein employ another $13 \%$, while banks and the private sector account for the remaining $43 \%$.

\footnotetext{
${ }^{1}$ Graham, B. Integrated Water Resources Management, Republic of the Marshall Islands Diagnostic Report. RMI Environmental Protection Authority, March 2007.

2 "Reports-Assessment Reports." Intergovernmental Panel on Climate Change, 2013. Accessed May 2013: http://www.ipcc.ch/ipccreports/tar/wg2/index.php?idp=671.

${ }^{3}$ Moore, B., Spatu, M., et al. Climate Change Baseline Assessment, Majuro Atoll, Republic of the Marshall Islands. New Caledonia: Secretariat of the Pacific Community, 2011.

4 "The RMI 2011 Census of Population and Housing Summary and Highlights Only." RMI Economic Policy, Planning, and Statistics Office, February 2012. www.doi.gov/oia/reports/upload/RMI-2011-Census-Summary-Report-on-Population-andHousing.pdf.

5 "The Marshall Islands." Office of Insular Affairs, undated. www.doi.gov/oia/islands/marshallislands.cfm.

6 "The World Factbook." Central Intelligence Agency, 2013. www.cia.gov/library/publications/the-worldfactbook/geos/rm.html.

7 "The RMI 2011 Census of Population and Housing Summary and Highlights Only." RMI Economic Policy, Planning, and Statistics Office, February 2012. www.doi.gov/oia/reports/upload/RMI-2011-Census-Summary-Report-on-Population-andHousing.pdf.

8 "National Accounts Main Aggregates Database." United Nations, 2013. http://unstats.un.org/unsd/snaama/selbasicFast.asp.

9 "Republic of the Marshall Islands Preliminary Conclusions of the 2012 IMF Staff Visit." International Monetary Fund, November 2012. www.imf.org/external/np/ms/2012/110712.htm.
} 
Annual wages average $\$ 4,800$ in the private sector, $\$ 12,200$ in the public sector, and $\$ 16,600$ at the U.S. Army base. The highest average sector wage is $\$ 17,000$ and is found in banking. ${ }^{10}$

The RMI economy experienced negative growth in 2008 and 2009 during the international recession. In June 2008, the government of the RMI declared a state of economic emergency due to high food and fuel prices. ${ }^{11}$ Recent strong economic growth in 2010 is attributed to low inflation and expansion of the fisheries sector, according to a DOI report. ${ }^{12}$ However, growth in 2011 was less than 1\%, blamed in part on high commodity prices.

\subsection{Compact of Free Association}

In signing the Compact of Free Association Agreement in 1986, the Marshall Islands became a freely associated state with close ties to the United States, mutually terminating the U.S. trusteeship over the islands that had been assumed after World War II. Under the Compact, the Marshall Islands became a sovereign nation, but as amended in fiscal year (FY) 2004, the U.S. government provides annual payments to the government of the RMI through FY 2023. The broad goal of the payments is to assist economic development towards "self-reliance." 13,3 Payments include grants, trust fund contributions (for use after FY 2023 annual payments cease), and lease payments for U.S. Department of Defense (DOD) use of multiple islets in the waters around the Kwajalein Atoll. Grant money goes toward projects selected by the RMI, but the projects are reviewed and approved through a joint committee of both U.S. and RMI government personnel to "strengthen management and accountability." "Grant money is disbursed to support the following areas: education, health, infrastructure, environment, private sector, and capacity building, with some money specifically allocated to "address the special needs of the community of Ebeye ... and other communities within the Kwajalein Atoll."15

Total Compact payments were \$70.8 million in FY 2012 and included \$35.42 million for the annual grant, \$12.5 million for the trust fund, and \$17.01 million to Kwajalein landowners for lease payments. ${ }^{16}$ A breakdown of the $\$ 35.42$ million of the annual grant by sector is shown in Figure 3 . There is also an additional \$5.9 million provided under the Supplemental Education Grant.

\footnotetext{
${ }^{10}$ Republic of the Marshall Islands: Statistical Appendix. International Monetary Fund, December 2011. www.imf.org/external/pubs/ft/scr/2011/cr11337.pdf.

${ }^{11} \mathrm{http}: / /$ articles.janes.com/articles/Janes-Sentinel-Security-Assessment-Oceania/Security-Marshall-Islands.html

${ }^{12}$ Budget Justifications and Performance Information, Fiscal Year 2013, Department of the Interior, Office of Insular Affairs. Washington, D.C.: U.S. Department of the Interior, Office of Insular Affairs, fiscal year 2013. www.doi.gov/archive/oia/budget/FY2013 Budget Justification.pdf.

${ }^{13}$ Compact of Free Association: Implementation Activities Have Progressed, but the Marshall Islands Faces Challenges to Achieving Long-Term Compact Goals. Washington, D.C.: U.S. Government Accountability Office, September 2007. www.gao.gov/new.items/d071258t.pdf.

14 “About JEMCO and JEMFAC.” U.S. Department of the Interior, undated. www.uscompact.org/about/jems.php.

15 "Compact of Free Association as Amended (Implementation) Act 2004 [41 MIRC Ch 1], Marshall Islands Revised Code 2004, TITLE 41 - Compact of Free Association.” PacLII, 2013. www.paclii.org/mh/legis/consol_act new/cofaaaa2004457/.

${ }^{16}$ Compact of Free Association: Implementation Activities Have Progressed, but the Marshall Islands Faces Challenges to Achieving Long-Term Compact Goals. Washington, D.C.: U.S. Government Accountability Office, September 2007. www.gao.gov/new.items/d071258t.pdf.
} 


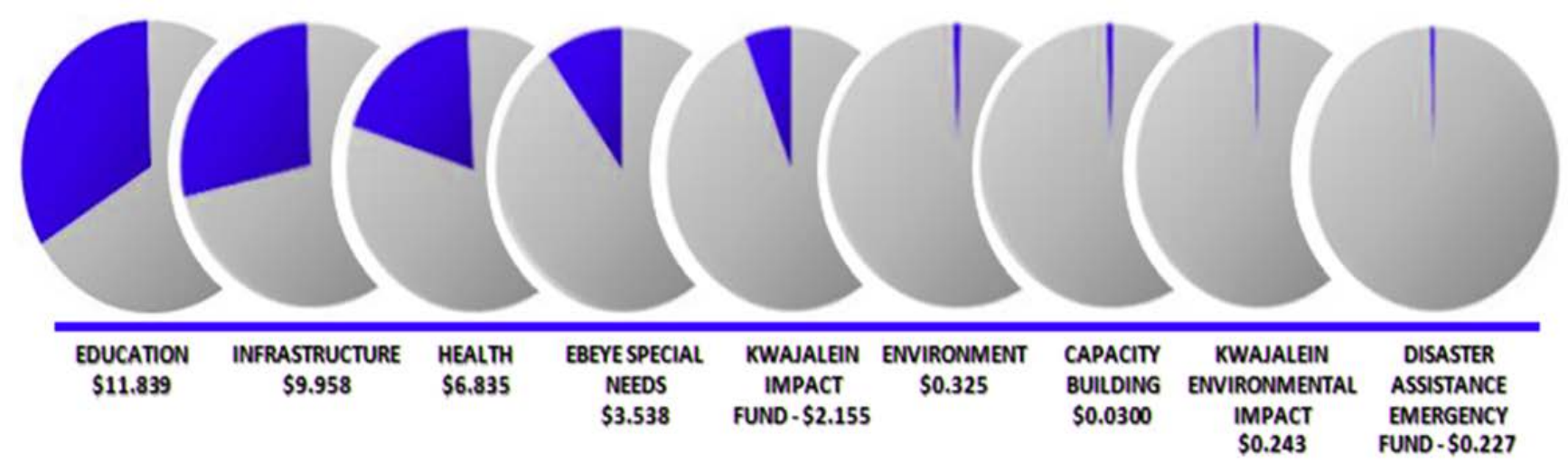

Figure 3. Breakdown of 2012 Compact annual grant

Compact grant expenditures specific to the energy sector could not readily be found in any database or annual summary reports. Grant spending within the $\$ 9.958$ million infrastructure item in Figure 3 did not include expenditures in the electrical power sector. However, in the FY 2009 Compact Infrastructure Grant, \$1 million was allocated to Marshalls Energy Company (MEC) for the overhaul of Majuro power plant generators. In addition, the Ebeye Special Needs fund and the Kwajalein Impact Fund are intended to "support and improve the infrastructure and delivery of services" on Ebeye and elsewhere in the Kwajalein Atoll. Documents obtained by the NREL assessment team indicate fairly significant expenditures on Ebeye to support power plant operations, and to cover fuel costs and infrastructure improvements. Between May 2006 and March 2013, approximately \$10.9 million of Compact grant money was spent on diesel fuel for the Ebeye power plant, $\$ 965,000$ on generator repairs and spare parts, \$2.5 million on power plant operations, and approximately another $\$ 1.1$ million to pay for "midcorridor electric billings," 17 which are payments to the utility to cover the electrical bills of persons displaced from DOD-leased lands in Kwajalein Atoll's mid-corridor and relocated to a section of Ebeye. Lastly, during the site visit, Ebeye utility personnel indicated that three new generator engines were recently purchased and installed using "DOI money." Direct reference to this project was not found in documentation reviewed by the assessment team, but these were also likely funded from Compact grants.

In total, data obtained by the assessment team indicates that over $\$ 15.9$ million has been spent on Ebeye for fuel; electricity bill payments; and power plant operations, maintenance, and repair between 2006 and 2013.

\footnotetext{
${ }^{17}$ Kwajalein Impact Fund Drawdown Report. U.S. Department of State, undated. www.uscompact.org/files/RMI\%20Publications/Sector\%20Publications/Kwajalein\%20Development\%20Fund/Kwajalein\%2 0Impact $\% 20$ fund $\% 20$ Report.pdf.
} 


\section{Power Sector Overview}

Approximately $75 \%$ of the RMI population has access to grid electricity; $92 \%$ in the urban areas of Majuro and Ebeye, and $32 \%$ in the rural outer islands. ${ }^{18}$ Some outer islands have central power plants, some of which run during limited hours of the day. Other remote populations receive electricity services from photovoltaic battery systems provided by international donors and maintained by the central utility.

There are two utility companies. Both are state-owned enterprises operating under a board appointed by the president's cabinet. The current cost of electricity for utility customers in the RMI is $\$ 0.50 /$ kilowatthours $(\mathrm{kWh})$ for government, $\$ 0.49 / \mathrm{kWh}$ for commercial, and $\$ 0.43 / \mathrm{kWh}$ for residential customers. ${ }^{19}$ Roughly $60 \%{ }^{20}$ of residential customers receive a subsidized "lifeline" rate, which is $\$ 0.41 / \mathrm{kWh}$ when consuming less than $500 \mathrm{kWh} /$ month. Outer-island homes with off-grid solar systems pay a $\$ 5 / \mathrm{month}$ lease to MEC for maintenance.

One important factor contributing to the high cost of electricity is that the RMI's small, remote, and dispersed population means there are virtually no economies of scale in electricity production.

Additionally, the power sector is challenged by the following:

- Aging infrastructure - Generators, transmission and distribution systems, and other infrastructure are outdated and in need of upgrades. Inefficiencies in generation and line losses are examples of the challenges this creates.

- Corrosive environment - The RMI's low elevation, absence of wind barriers, and narrow land areas make electrical equipment highly vulnerable to ocean spray, which is highly corrosive.

- Inadequate maintenance - The capacity and funds are not always readily available to address maintenance requirements.

- High fuel costs - The RMI's remote location adds significantly higher transportation costs to the price of fuel, and the lack of economies of scale prevents the RMI from taking advantage of bulk fuel purchases.

- Revenue shortfalls - Electricity rates do not cover total costs, and the landowner's electricity concession results in extra costs of about $\$ 1.8$ million/year.

The utilities' inability to balance operating budgets is due to a number of factors, including price controls that do not cover costs (both for electricity from central power stations and user fees for outerisland residential solar systems), flat tariff structures for all districts served by central plants, and exemptions or credits on utility payments for landowners.

\subsection{Local Entities Involved in the Power Sector}

This section describes the principal entities involved in the power sector.

\footnotetext{
${ }^{18}$ IRENA Policy Brief: Policy Challenges for Renewable Energy Deployment in Pacific Island Countries and Territories. International Renewable Energy Agency, 2012. www.irena.org/DocumentDownloads/Publications/Policy_Challenges_for_Renewable_Energy_Deployment_PICTs.pdf. 19 "Marshalls Energy Company.” Marshalls Energy Company, Inc., 2005. Accessed March 2013: www.mecrmi.net. ${ }^{20}$ Republic of the Marshall Islands National Energy Policy and Energy Action Plan, Volume 1: National Energy Policy. Republic of the Marshall Islands Ministry of Resources and Development, September 2009. marshall.wetserver.net/livefiles/rminationalenergypolicy-2009 aboutdownloads_59.pdf.
} 


\subsubsection{Utilities}

Two public electric utilities sharing a single oversight board operate in the RMI. Both are semiautonomous state-owned enterprise of the RMI government. The MEC operates six districts with average loads ranging from 15 kilowatts $(\mathrm{kW})$ on Rongrong Island to 7 megawatts (MW) on Majuro. Kwajalein Joint Utilities Resources (KAJUR) serves only Ebeye in the Kwajalein Atoll and has an average load of 1.7 MW. Virtually all power generation is from diesel reciprocating engine generators, common in small power systems. Electricity tariffs are uniform across all districts and range from $\$ 0.41 / \mathrm{kWh}$ for residential customers to $\$ 0.50 / \mathrm{kWh}$ for the government.

In addition to these centralized plants, MEC owns and operates photovoltaic-battery systems on lesspopulated, rural islands. All of these systems were provided through grants or were fully funded by international donors, but MEC is responsible for maintaining them and collecting monthly usage fees. There are approximately 1,500 residential solar systems ${ }^{21}$ and three photovoltaic (PV) systems on rural schools ranging in size from $6 \mathrm{~kW}$ direct current (DC) to $9 \mathrm{~kW} \mathrm{DC.}{ }^{22}$

In addition to electricity, MEC provides sewer and wastewater services on Majuro, and KAJUR provides freshwater, saltwater (for toilets), and sewer services on Ebeye.

\subsubsection{Regulatory Body}

There is no independent body regulating the utilities in the RMI. ${ }^{23}$ The president and his cabinet are the regulatory authority for all utilities in the RMI.

\subsubsection{Ministry of Resources and Development}

The Ministry of Resources and Development (MRD) was established in 1979 under the RMI constitution. It is part of the president's cabinet and is the primary government body responsible for agriculture, energy, trade, and investment. Its mission is to develop these sectors in a "sustainable and productive manner." MRD is responsible for coordination of the RMI National Energy Task Force. ${ }^{24}$

Within MRD, the Energy Planning Division has two full-time staff and a temporary energy advisor with petroleum expertise under a one-year contract funded by the Australian Agency for International Development (AusAID). The temporary energy advisor's time is split between MEC (40\%) and MRD (60\%). The Energy Planning Division is responsible for developing, implementing, and coordinating energy policy. ${ }^{25}$

The Alternative Energy Fund Act of 1989 created a revolving loan fund for development and operation of alternative energy systems to be utilized by the energy services unit of the MRD. ${ }^{26}$ The status of this fund and history of programs executed under it were not clear at the time this report was authored.

\footnotetext{
${ }^{21}$ Republic of the Marshall Islands National Energy Policy and Energy Action Plan, Volume 1: National Energy Policy. Republic of the Marshall Islands Ministry of Resources and Development, September 2009. marshall.wetserver.net/livefiles/rminationalenergypolicy-2009 aboutdownloads 59.pdf.

22 "Marshalls Energy Company.” Marshalls Energy Company, Inc., 2005. Accessed March 2013: www.mecrmi.net.

${ }^{23}$ Irwin, T.; Yamamoto, C. Some Options for Improving the Governance of State-Owned Electricity Utilities. The World Bank, 2004. Accessed April 12, 2011: www.regulationbodyofknowledge.org/externalDocument/irwinSome/.

24 "National Energy Profile: Republic of the Marshall Islands, Pacific." United Nations Development Programme (UNDP), 2012.

${ }^{25}$ RMI Country Energy Security Indicator Profile 2009. Suva, Fiji: Energy Programme, Economic Development Division, Secretariat of the Pacific Community, 2012.

${ }^{26}$ Republic of the Marshall Islands Ministry of Resources and Development Strategy and Action Plan 2005-2010. The Republic of the Marshall Islands Ministry of Resources and Development, 2004. www.preventionweb.net/files/28165 rmirdstrategicplan.pdf.
} 
The Energy Services Program’s key objectives are to:

- Provide access to electricity in the outer islands to contribute to their economic development

- Provide energy policy that contributes to social and economic development of the RMI. ${ }^{27}$

\subsubsection{Economic Policy, Planning, and Statistics Office}

Under the Office of the President, the Economic Policy, Planning, and Statistics Office (EPPSO) is an advisory body to the RMI government responsible for:

- Economic policy and strategic planning

- Statistics and analysis, including census duties

- Monitoring, evaluation, and coordination of aid.

Sector-specific statistics are collated by EPPSO and published on their website. However, the most recent data provided for energy and water sectors are from 2004.

\subsection{Current Policy and Standards}

Across the global landscape, many states, territories, local governments, and communities are turning to policy as a way to lay the foundation for a green economy and encourage the implementation of clean energy technologies. Well-designed policies could be an effective tool for the RMI to implement its energy efficiency and renewable energy goals, increase energy diversity, and decrease dependence on imported fossil fuels. Clean energy technologies also have environmental benefits, such as reducing emissions, water consumption, thermal pollution, and adverse land-use impacts. Including these environmental effects (referred to as "externalities" by economists) can be beneficial in a cost-benefit analysis that analyzes the advantages and disadvantages of continued use of fossil fuels.

The RMI has few policies addressing energy efficiency and renewable energy technologies, but has established future policy goals through their National Energy Policy, which is detailed in Section 4.3. Current policies and standards are described below.

\section{Vehicles}

In 2005, the RMI cabinet approved a new policy requiring all government departments to purchase only diesel-fueled vehicles, which are considerably more efficient than gasoline for the same engine size. This policy could potentially have a strong impact on RMI's fossil fuel consumption because transportation makes up about two-thirds of the country's fuel use. However, the policy does not seem to be enforced. $^{28}$

\section{Tariffs}

A standard formula for rate tariffs, ${ }^{29}$ developed in 2006, is used across the RMI to provide identical rates by sector in all power districts. The rate formula was approved by the president's cabinet. The rate structure is insufficient to recover all operating costs and, due to the uniformity across islands, provides a subsidy to higher-cost districts. During an NREL site visit, one utility employee said that rates are set

\footnotetext{
27 "Ministry of Resources and Development." RMI Ministry of Resources and Development, 2008. http://rmirnd.net/.

${ }^{28}$ Republic of the Marshall Islands National Energy Policy and Energy Action Plan. The Republic of the Marshall Islands Ministry of Resources and Development, September 2009. Accessed Aug. 24, 2012:

http://marshall.wetserver.net/livefiles/rminationalenergypolicy-2009_aboutdownloads_59.pdf.

${ }^{29}$ See the Glossary for the definition of rate tariffs.
} 
by the government at a level that is considered affordable, not at a level that provides sufficient revenue to cover utility expenses.

\section{Utility Regulation}

As indicated above, there is no independent utility regulator in the RMI. The president and his cabinet act as the sole regulatory authority. The utility board of directors provides the policies necessary to implement legislation, independent oversight of the utility operations and rates, and the separation between political actions and utility business practices that is necessary to provide electricity and other services in the most economically efficient way.

\section{Interconnection of Renewable Generation with the Grid}

There is no policy that explicitly permits or prohibits utility customers from connecting their own renewable energy systems to the power grid. ${ }^{30}$ Interconnection policies are designed to allow utility customers to interconnect generation assets to the grid while ensuring the safety and reliability of the electrical grid. Good policies describe the responsibilities of each party, necessary steps, timelines, and fees.

\section{Net Metering}

The RMI does not have a net metering policy. ${ }^{31}$ Such policies are established as an incentive to credit the system owner for energy generated that is not consumed on site but that flows into the electrical grid and is consumed by other utility customers. Net metering policies provide a credit for net electricity generation, typically at retail rates, and allow carryover of the credit from month to month. Typically, any net excess generation is forfeited at the end of an annual true-up period. Some utilities will pay for net excess at the end of the true-up period, often at a rate below the customer's retail rate. Some utilities offer net billing instead of net metering. Net billing credits the customer-generator for excess energy sent to the grid but at a rate lower than the customer's retail rate. Net billing is not as beneficial as net metering to the customer-generator, and therefore is a weaker incentive than net metering.

\section{Financial Incentives}

There are no grants, production incentives, or capacity-based incentives offered by the government of the RMI or utility providers to promote private investment in renewable energy or energy efficiency technologies by utility customers.

\section{Independent Power Producers}

There is no contractual framework for third-party power generation. ${ }^{25}$ Consequently, there are currently no independent power producers operating in the Marshall Islands and selling electricity to the utilities or large commercial or industrial power consumers.

\subsection{National Energy Policy and Energy Action Plan}

As with so many Pacific island nations, 2008 brought exceptional fuel spikes prompting in depth reflection on energy policy. During the first half of 2008, the cost of fuel oil had increased on average from $\$ 2.51 /$ gallon to $\$ 4.11 /$ gallon. As a response to this crisis, a state of economic emergency was declared on July 3, 2008, which led to direct action. The energy crisis in the RMI led the government to conduct an examination of key issues, an investigation that was funded by the Asian Development Bank

\footnotetext{
${ }^{30}$ Pickering, I., Marshalls Energy Company electrical engineer. Interview, Dec. 12, 2012.

${ }^{31}$ Renewables 2012: Global Status Report. Paris: Renewable Energy Policy Network for the $21^{\text {st }}$ Century, 2012. http://www.map.ren21.net/GSR/GSR2012_low.pdf.
} 
(ADB). The findings of the investigation guided the government to develop the RMI National Energy Policy and Energy Action Plan (NEPEAP), utilizing funding from the European Union through its REP5 Pacific Energy Program. The NEP was completed in 2009.

Volume I of the NEPEAP addresses energy policy and outlines numerous renewable energy and energy efficiency goals and projects. Volume II, the NEPEAP, lays out project parameters, including the organization(s) responsible, project priorities, time frames, performance indicators, budget requirements, and potential funding sources. The NEPEAP was created during a time of intense focus created by sharply increasing fossil fuel prices. This sense of urgency led to quick action (the NEPEAP only took about one year to produce) in an attempt to solve the crisis.

In his introduction to the plan, Minister of Resources and Development Mattlan Zackhras wrote:

There must be an immediate and significant reorientation of the energy sector, with changes to reduce energy demand and diversify energy supply. The RMI must significantly improve energy efficiency and begin shifting its reliance away from oil and toward practical and affordable renewable energy sources for its urban and rural communities. $^{32}$

The following figure depicts the RMI's approach to tackling its energy issues and the four energy sectors targeted for attention.

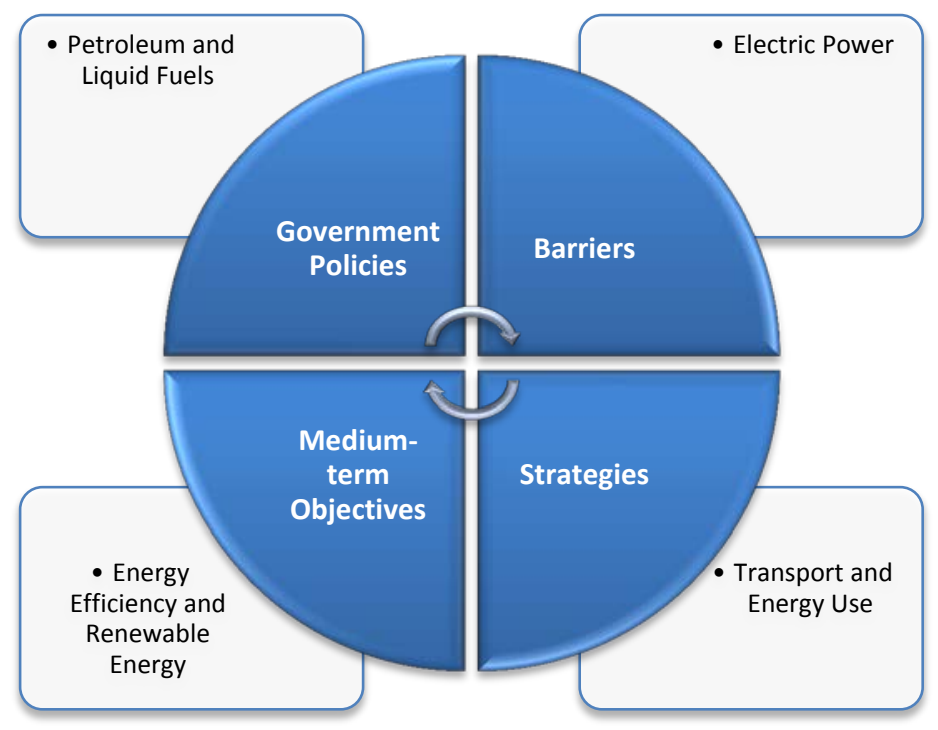

Figure 4. Areas targeted in the National Energy Policy

The NEPEAP's development objective is to achieve "an improved quality of life for the people of the Marshall Islands through clean, reliable, affordable, accessible, environmentally appropriate, and sustainable energy services."

\footnotetext{
${ }^{32}$ Republic of the Marshall Islands National Energy Policy and Energy Action Plan, Volume 1: National Energy Policy. Republic of the Marshall Islands Ministry of Resources and Development, September 2009, pg. i. marshall.wetserver.net/livefiles/rminationalenergypolicy-2009_aboutdownloads_59.pdf.
} 
The following goals were established by the RMI NEP:

- Electrification of $100 \%$ of all urban households and 95\% of rural outer atoll households by 2015

- $20 \%$ indigenous renewable energy by 2020

- $50 \%$ energy efficiency improvements of households and businesses, and $75 \%$ of government buildings, by 2020

- $20 \%$ reduction of supply side energy losses from MEC by 2015

- $40 \%$ reduction of fossil fuels used by the government by 2020 .

These goals are not legally binding and were developed based on previous assessments and estimates of resources and baseline data. The feasibility of these goals still needs to be evaluated and updated based on the RMI's present energy usage and resources. 


\section{Power Sector Baseline Data}

Electrical generation in the RMI, like most isolated, small power grids, relies on diesel-powered engine generators. The diesel engines used in the RMI are modular and allow easy scaling to meet load growth ${ }^{33}$ by adding units. They are robust, relatively straightforward to maintain, and highly flexible in their ability to follow demand. These attributes are a good fit to the poor economies of scale in remote islands with low populations; however, reliance on diesel raises electricity costs for island communities, with costs that can be five to 10 times higher than U.S. mainland prices. An estimated $67 \%{ }^{25}$ of diesel imports and approximately $30 \%{ }^{34}$ of all liquid fossil fuel imports are used for electricity generation in the RMI. An estimated $99.6 \%$ of annual RMI electricity use is provided by diesel generation, and approximately $0.4 \%$ is currently provided by grid-connected PV.

\subsection{Central Plant Power Districts}

Table 1 shows population data and land area by atoll and island, and indicates which islands are served, at least in part, by a central power station or PV-battery systems. The information on electrification was collected from multiple reports and MEC's website and may be incomplete. In those regions that have central power plants, not all individuals are grid-connected. High electrification rates are found on Majuro and Ebeye. In 2006, 93\% of residences on Majuro had access to grid electricity, while the rate on Ebeye was $97 \% .{ }^{35}$ The assessment team was unable to obtain data for the other districts.

\footnotetext{
${ }^{33}$ See the Glossary for the definition of load.

${ }^{34}$ Republic of the Marshall Islands National Energy Policy and Energy Action Plan, Volume 1: National Energy Policy. Republic of the Marshall Islands Ministry of Resources and Development, September 2009. marshall.wetserver.net/livefiles/rminationalenergypolicy-2009_aboutdownloads_59.pdf.

${ }^{35}$ Republic of the Marshall Islands National Energy Policy and Energy Action Plan, Volume 1: National Energy Policy. Republic of the Marshall Islands Ministry of Resources and Development, September 2009. marshall.wetserver.net/livefiles/rminationalenergypolicy-2009 aboutdownloads_59.pdf.
} 
Table 1. RMI 2011 population, land area, and electrification by atoll and island

\begin{tabular}{|c|c|c|c|c|c|}
\hline Municipality & $\begin{array}{l}\text { Population } \\
\text { (Number } \\
\text { of People) }\end{array}$ & $\begin{array}{l}\text { Population } \\
\text { (Percentage) }\end{array}$ & $\begin{array}{c}\text { Area } \\
\text { (square } \\
\text { miles) }\end{array}$ & $\begin{array}{l}\text { Central } \\
\text { Power } \\
\text { Station }\end{array}$ & $\begin{array}{l}\text { PV- } \\
\text { battery } \\
\text { service }\end{array}$ \\
\hline Majuro Atoll & 27,797 & $52 \%$ & 4 & Yes & \\
\hline $\begin{array}{l}\text { Kwajalein } \\
\text { Atoll (Ebeye) }\end{array}$ & 11,408 & $21 \%$ & 6 & Yes & \\
\hline Arno Atoll & 1,794 & $3 \%$ & 5 & & Yes \\
\hline Jaluit Atoll & 1,788 & $3 \%$ & 4 & Yes & \\
\hline $\begin{array}{l}\text { Ailinglaplap } \\
\text { Atoll }\end{array}$ & 1,729 & $3 \%$ & 6 & & \\
\hline Wotje Atoll & 859 & $2 \%$ & 3 & Yes & \\
\hline Namu Atoll & 780 & $1 \%$ & 2 & & Yes \\
\hline Mili Atoll & 738 & $1 \%$ & 6 & & \\
\hline Ebon Atoll & 706 & $1 \%$ & 2 & & \\
\hline $\begin{array}{l}\text { Maloelap } \\
\text { Atoll }\end{array}$ & 682 & $1 \%$ & 4 & & \\
\hline Enewetak & 664 & $1 \%$ & 2 & & \\
\hline Kili & 548 & $1 \%$ & & Yes & \\
\hline $\begin{array}{l}\text { Namdrik } \\
\text { Atoll }\end{array}$ & 508 & $1 \%$ & 1 & & Yes \\
\hline Aur Atoll & 499 & $1 \%$ & 2 & & \\
\hline Utirik Atoll & 435 & $1 \%$ & 1 & & \\
\hline Likiep Atoll & 401 & $1 \%$ & 4 & & \\
\hline Ujae Atoll & 364 & $1 \%$ & 1 & & \\
\hline Mejit Island & 348 & $1 \%$ & 1 & & Yes \\
\hline Lae Atoll & 347 & $1 \%$ & 1 & & \\
\hline Ailuk Atoll & 339 & $1 \%$ & 2 & & \\
\hline Lib Island & 155 & $0.3 \%$ & 0 & & \\
\hline Wotho Atoll & 97 & $0.2 \%$ & 2 & & Yes \\
\hline Jabat Island & 84 & $0.2 \%$ & 0 & & \\
\hline $\begin{array}{l}\text { Rongelap } \\
\text { Atoll }\end{array}$ & 79 & $0.1 \%$ & 3 & & \\
\hline Bikini & 9 & $0.0 \%$ & 0 & Yes & \\
\hline Ujelang & 0 & $0.0 \%$ & & & \\
\hline $\begin{array}{l}\text { Total } \\
\text { Population }\end{array}$ & 53,158 & & & & \\
\hline
\end{tabular}

Source: Wikimedia Commons (http://commons.wikimedia.org/wiki/File:MH_-map_A.png)

The total electricity generated, and breakdown by district, are provided for Majuro, Ebeye, and Jaluit in Table 2. Power plant data in this table and all subsequent analysis in this report were provided by utility personnel at MEC and KAJUR. Approximately $75 \%$ of the RMI population resides in these three districts. Because the vast majority of the population, government bodies, and commercial enterprises are located on Ebeye and Majuro, the data provides a good picture of RMI's power sector. 
Table 2. Generation data for Majuro, Ebeye, and Jaluit for 2012

\begin{tabular}{|c|c|c|c|c|}
\hline & Sum & Majuro & Ebeye & Jaluit \\
\hline Average Plant Load (MW) & 8.9 & 7.0 & 1.8 & 0.09 \\
\hline Total Energy Generated (MWh) & 77,495 & 61,324 & 15,400 & 771 \\
\hline Total Energy Sales (MWh) ${ }^{a}$ & 67,287 & 52,125 & 14,528 & 634 \\
\hline $\begin{array}{l}\text { Total Fuel Usage } \\
\text { (barrels of \#6 fuel oil) }\end{array}$ & 120,169 & 95,619 & 23,174 & 1,376 \\
\hline Heat Rates (Btu/kWh) & 9,769 & 9,823 & 9,481 & 11,244 \\
\hline
\end{tabular}

${ }^{a}$ Data not provided for Majuro and Ebeye; estimated from other references.

Source: Utility personnel at Marshalls Energy Company and Kwajalein Atoll Joint Utilities Resources

\subsection{Electricity Cost Tariffs}

The current cost of electricity for grid-connected utility customers is shown in Table 3. A "lifeline" tariff is available to lower-income residential customers who consume less than $500 \mathrm{kWh} / \mathrm{month}$ of electricity. Outer-island homes with off-grid solar systems pay a $\$ 5 /$ month lease to MEC for maintenance. It is not known what number of outer island homes is actually able to pay the $\$ 5$ per month cost and how effective the mechanisms for collections are.

Table 3. Utility electric costs in the RMI

\begin{tabular}{|l|l|}
\hline Sector & Cost \\
\hline Government & $\$ 0.50 / \mathrm{kWh}$ \\
\hline Commercial & $\$ 0.49 / \mathrm{kWh}$ \\
\hline Residential & $\$ 0.43 / \mathrm{kWh}$ \\
\hline Residential Lifeline & $\$ 0.41 / \mathrm{kWh}$ \\
\hline
\end{tabular}

Source: Marshalls Energy Company

\subsection{Major Energy Users}

Data on electricity usage by sector was not provided to the assessment team by MEC or KAJUR. Incomplete information on consumption by end users was gleaned from other reports and is summarized in this section.

A 2006 report $^{36}$ commissioned by the DOI listed the top ten electricity consumers on Majuro. These users accounted for approximately $16 \%$ of the total island electricity consumption. Those consumers and their energy use are shown in Table 4 for 2006. In that year, Marshall Island's Fisheries was the top user with an average load of $271 \mathrm{~kW}$ and $3.5 \%$ of total electricity sales. The list indicates that the second highest user on Majuro that year was the Triple J Payless grocery store, accounting for $2.9 \%$ of MEC's total electricity sales. Two grocery stores are on the top ten list, and combined they account for $3.2 \%$ of MEC's electricity sales, likely due to high power use of refrigeration and freezers.

\footnotetext{
${ }^{36}$ United States of America Insular Areas Energy Assessment Report: An Update of the 1982 Territorial Energy Assessment. Pacific Power Association, 2006.
} 
Table 4. Top ten electricity consumers on Majuro in 2006

\begin{tabular}{|l|r|r|r|}
\hline & $\begin{array}{c}\text { Energy Use } \\
\text { (kWh/year) }\end{array}$ & \multicolumn{1}{c|}{$\begin{array}{c}\text { Average } \\
\text { Load (kW) }\end{array}$} & $\begin{array}{c}\text { Fraction of } \\
\text { 2010 Total }\end{array}$ \\
\hline Marshall Islands Fisheries & $2,371,920$ & 270.8 & $3.5 \%$ \\
\hline Triple J Payless & $1,938,600$ & 221.3 & $2.9 \%$ \\
\hline Capitol Building & $1,771,200$ & 202.2 & $2.6 \%$ \\
\hline Marshall Islands Resort & $1,118,880$ & 127.7 & $1.7 \%$ \\
\hline National Telecommunications Authority & 908,160 & 103.7 & $1.4 \%$ \\
\hline Majuro Public Hospital & 758,400 & 86.6 & $1.1 \%$ \\
\hline Amata International Airport & 721,920 & 82.4 & $1.1 \%$ \\
\hline Formosa Supermarket & 555,840 & 63.5 & $0.8 \%$ \\
\hline Robert Reimer's Enterprises & 366,720 & 41.9 & $0.5 \%$ \\
\hline Ministry of Education & 198,720 & 22.7 & $0.3 \%$ \\
\hline Totals for Top 10 Electricity Consumers & $10,710,360$ & 1,223 & $16 \%$ \\
\hline Totals for all of Majuro & $67,215,000$ & 7,673 & \\
\hline
\end{tabular}

Source: Utility personnel at Marshalls Energy Company and Kwajalein Atoll Joint Utilities Resources

Although the RMI's state-owned copra processing facility, Tobolar Copra Processing Authority, is absent from the 2006 list, more recent data suggests Tobolar is a high energy consumer on Majuro. An independent auditor's report of the Tobolar Copra Processing Authority for FY 2011 itemizes electricity costs of approximately $\$ 350,000 .{ }^{37}$ Assuming current energy costs of $\$ 0.50 / \mathrm{kWh}$, their annual energy consumption is estimated to be $700,000 \mathrm{kWh} /$ year, or an average load of $80 \mathrm{~kW}$.

\subsection{Historical Trends}

Historical fuel usage by MEC on Majuro for years 2003 through 2012 is shown in Figure 5. Data was provided by MEC personnel. The figure shows the number of barrels of \#6 fuel oil used in the power plants. Consumption in 2012 is down $29 \%$ from the maximum consumption in 2004. This reflects the fact that the total annual electricity demands at the plant are down $26 \%$ from the high in 2004 . The annual average load in 2004 was $9.4 \mathrm{MW}$, while in 2012 it was down to $7.0 \mathrm{MW}$.

\footnotetext{
${ }^{37}$ Tobolar Processing Plant, Inc. Financial Statements and Independent Auditors' Report, Years Ended September 30,2011 and 2010 (As Restated). Deloitte \& Touch LLP, March 2012.

www.rmioag.com/files/RMI/Component\%20Units/Tobolar_FY2011/Financial\%20Statement\%20(FINAL\%2003192012).pdf
} 


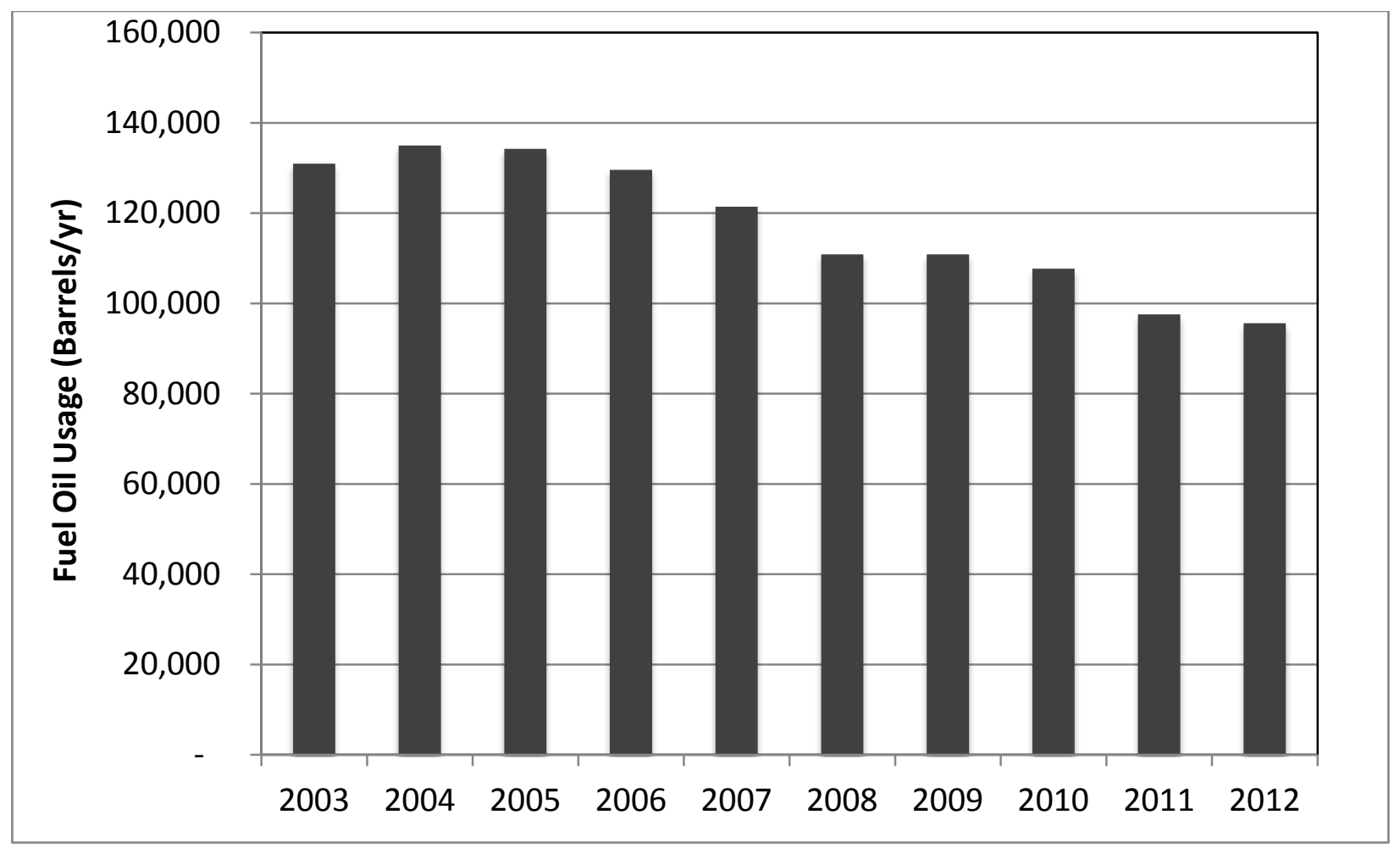

Figure 5. Downward trend in fuel consumption at Majuro power plants

Declining fuel consumption is speculated to be the result of declining electricity demand due to three primary factors: increased cost of electricity from increasing fuel costs, introduction of prepaid meters, and increased enforcement against theft. Historical data for Ebeye and Jaluit could not be secured, but it seems reasonable to assume these districts showed similar trends as they were, in general, subject to the same set of forces. This is supported by statements made by the general manager of KAJUR during the stakeholder meeting on Ebeye organized by the NREL assessment team. He reported that peak loads in excess of $3 \mathrm{MW}$ to $3.5 \mathrm{MW}$ occurred regularly ten years ago while peak loads currently are $1.9 \mathrm{MW}$. He attributed this reduction to the introduction of a prepaid meter program. Prepaid meters now account for about $95 \%$ of all meters on Ebeye.

\subsection{Generation Facilities}

Conventional fossil fuel generators in the RMI are all reciprocating compression-ignition diesel engines. The diesel generation assets are listed by island district in Table 5. 
Table 5. Diesel-generation plants by island district

\begin{tabular}{|l|l|}
\hline District & $\begin{array}{l}\text { Installed Generation } \\
\text { and Date Installed }\end{array}$ \\
\hline Majuro & $10 \mathrm{MW}(1982)$ \\
& $3.3 \mathrm{MW}(1992)$ \\
& $12.8 \mathrm{MW}(1999)$ \\
& $26.1 \mathrm{MW}$ total \\
\hline Rongrong Island, Majuro Atoll & $0.12 \mathrm{MW}(2003)$ \\
\hline Ebeye & $3.6 \mathrm{MW}(2012)$ \\
\hline Jaluit & $0.55 \mathrm{MW}(1991)$ \\
\hline Wotje & \\
\hline Kili Island & $0.55 \mathrm{MW}(2003)$ \\
\hline Bikini Atoll & $1.8 \mathrm{MW}$ (1990) \\
& \\
\hline
\end{tabular}

Source: Marshalls Energy Company

Power plant heat rates for three primary districts are shown in Table 6. Heat rate is a figure that describes how much fuel, in British thermal units, a plant consumes to generate each unit of electricity. Plants with lower heat rates have higher efficiencies. Heat rates in the table are expressed using the fuel's higher heating value (HHV), the convention used in United States. These values were calculated from data provided during the NREL assessment trip.

Table 6. Power plant heat rates for Majuro, Ebeye, and Jaluit for 2012

\begin{tabular}{|l|r|r|r|r|}
\hline & $\begin{array}{c}\text { Weighted } \\
\text { Average }\end{array}$ & Majuro & Ebeye & \multicolumn{1}{c|}{ Jaluit } \\
\hline Heat Rate, HHV (BTU/kWh) & 9,769 & 9,823 & 9,481 & 11,244 \\
\hline
\end{tabular}

Source: Utility personnel at Marshalls Energy Company and Kwajalein Atoll Joint Utilities Resources

These generator efficiencies are within a reasonable range. However, an analysis ${ }^{38}$ funded by the DOI identifies excessive energy consumption within the power plant on Majuro. The analysis estimates that almost $8.5 \%$ of all electricity generated by the plant is consumed within the plant to operate pumps, fans, other peripheral equipment, and plant facilities. Station use would typically be expected to be less than $5 \%$. With $6.4 \%$ losses in electrical distribution and rates of electricity theft exceeding $11 \%$, overall system losses are in excess of $25 \%$. This is a large number by any standard of measure.

During the assessment trip, stakeholders described capacity limitations of the local workforce and revenue challenges that hinder the performance of regular maintenance. Power system reliability, particularly in the outer islands, is poor, as there are regular unplanned outages. Utility budget deficits make it difficult to purchase necessary replacement parts or execute upgrades while insufficient capacity reserves force plant operators to run equipment that might otherwise need to be taken out of service for maintenance.

\footnotetext{
${ }^{38}$ Quantification of Energy Efficiency in the Utilities of the U.S. Affiliate States (excluding US Virgin Islands. Pacific Power Association, December 2010. http://www.ppa.org.fj/wp-content/uploads/2013/03/PPA-Consolidated-Report-onQuantification-of-Losses.pdf.
} 


\subsection{Existing Renewable Energy}

Small rural solar PV systems have been used on the outer islands in the RMI for at least a decade to provide basic electrical services to remote homes and clinics. An RMI rural electrification program continues to add additional off-grid PV-battery systems for outlying communities. The RMI's NEP projected that a total of 1,500 rural, stand-alone PV installations would be deployed by 2010 and increase to 2,800 or more by 2015 . The specific location and status of these installations could not be determined from the available data. These systems are generally financed by international donors and deployed in partnership with MEC.

On Majuro, there are two grid-connected PV systems of significant size, one on the roof of the Majuro Public Hospital $(205 \mathrm{~kW})$ and the other on top of buildings on the campus of the College of the Marshall Islands $(57 \mathrm{~kW})$. The hospital system was funded by Japan and installed in 2012. The combined size of these two systems is $262 \mathrm{~kW}$, representing about $2.2 \%$ of Majuro's current total electrical load.

Two smaller rooftop systems were seen on Majuro during the assessment trip but details of these systems are not known. MEC does not keep a list of grid-connected systems.

A single 10-kW wind turbine is operating on Majuro. It is an off-grid system using battery storage and provides power to a moored boat. In addition, a few small solar water heating (SWH) systems were noted on the campus of the College of the Marshall Islands. Table 7 is a list of systems identified during the assessment trip or described in other references.

Table 7. Partial list of existing renewable energy systems in RMI

\begin{tabular}{|c|c|c|c|c|}
\hline Atoll/Island & Technology & Type $^{a}$ & Details & Reference \\
\hline \multirow[t]{4}{*}{ Majuro } & PV & $\begin{array}{l}\text { Grid } \\
\text { connected }\end{array}$ & $\begin{array}{l}205 \mathrm{~kW} \\
\text { Majuro Public Hospital } \\
(2012)\end{array}$ & Assessment trip \\
\hline & PV & $\begin{array}{l}\text { Grid } \\
\text { connected }\end{array}$ & $\begin{array}{l}57 \mathrm{~kW} \\
\text { College of the Marshall Islands } \\
(2010)\end{array}$ & Assessment trip \\
\hline & Wind turbine & $\begin{array}{l}\text { Off-grid } \\
\text { battery }\end{array}$ & $10 \mathrm{~kW}$ & Assessment trip \\
\hline & SHW & N/A & $\begin{array}{l}\text { Approximately } 40 \mathrm{ft}^{2} \text { of collector } \\
\text { College of the Marshall Islands }\end{array}$ & Assessment trip \\
\hline Mejit & PV & $\begin{array}{l}\text { Off-grid } \\
\text { battery }\end{array}$ & $\begin{array}{l}\text { 9.2 kW-DC on Metjit Elementary } \\
\text { School (2009) }\end{array}$ & $\begin{array}{l}\text { Marshalls Energy Company } \\
\text { (accessed April 2013: } \\
\text { http://mecrmi.net/) }\end{array}$ \\
\hline Arno & PV & $\begin{array}{l}\text { Off-grid } \\
\text { battery }\end{array}$ & $\begin{array}{l}6.12 \mathrm{~kW} \text { at Ine Primary School } \\
(2009)\end{array}$ & $\begin{array}{l}\text { Marshalls Energy Company } \\
\text { (accessed April 2013: } \\
\text { http://mecrmi.net/) }\end{array}$ \\
\hline Namo Atoll & PV & $\begin{array}{l}\text { Off-grid } \\
\text { battery }\end{array}$ & $\begin{array}{l}6.12 \mathrm{~kW} \text { at Majkin Primary School } \\
(2009)\end{array}$ & $\begin{array}{l}\text { Marshalls Energy Company } \\
\text { (accessed April 2013: } \\
\text { http://mecrmi.net/) }\end{array}$ \\
\hline $\begin{array}{l}\text { Throughout } \\
\text { the RMI }\end{array}$ & PV & $\begin{array}{l}\text { Off-grid } \\
\text { battery }\end{array}$ & $\begin{array}{l}\text { Approximately }(1,500) 80 \text {-Watt to } \\
300 \text {-Watt residential systems } \\
\text { installed under various donor } \\
\text { programs over the last decade }\end{array}$ & $\begin{array}{l}\text { Volume I of the National } \\
\text { Energy Policy and Action Plan }\end{array}$ \\
\hline $\begin{array}{l}\text { Throughout } \\
\text { the RMI }\end{array}$ & $\begin{array}{l}\text { PV-powered } \\
\text { street lights }\end{array}$ & $\begin{array}{l}\text { Off-grid } \\
\text { battery }\end{array}$ & At least 6,088 units. & $\begin{array}{l}\text { Yokwe Online (accessed } \\
\text { January } \\
\text { 2013: http://yokwe.net/index.ph } \\
\text { p?module=News\&func=display } \\
\text { \&sid=3061) }\end{array}$ \\
\hline
\end{tabular}

${ }^{\mathrm{a}}$ See Section 6.4.1 for an explanation of grid-connected and off-grid systems.

Source: Utility personnel at Marshalls Energy Company and Kwajalein Atoll Joint Utilities Resources 
The rural electric systems are the property of $\mathrm{MEC}$, and residences are required to pay a monthly service charge intended to cover MEC's operation and maintenance costs. Initially, this charge was \$12/month, which was sufficient to cover all costs, including future battery replacements. However, in 2009, the president's cabinet reduced this monthly charge to $\$ 5 /$ household.

Solar street light fixtures were seen on Jaluit and on Majuro during the assessment trip. An online newspaper article indicates that the Republic of China has donated at least 6,088 systems of this type to the RMI. ${ }^{40}$

${ }^{39}$ Republic of the Marshall Islands National Energy Policy and Energy Action Plan, Volume 1: National Energy Policy. Republic of the Marshall Islands Ministry of Resources and Development, September 2009. marshall.wetserver.net/livefiles/rminationalenergypolicy-2009 aboutdownloads 59.pdf.

40 "Taiwan's Solar Project to Light-up Marshall Islands Basketball Courts.” Yokwe Online, July 9, 2012. Accessed March 2013: http://yokwe.net/index.php? module=News\&func=display\&sid=3061. 


\section{Regional and International Supporters}

The RMI is heavily dependent on compensation payments from the United States and other external assistance. Grants recently averaged $\$ 70$ million annually, or $45 \%$ of the RMI's GDP and $70 \%$ of its fiscal revenue. Japan, Taiwan, and Australia have all contributed significantly to the RMI, but the country's budget still remains highly dependent on the Compact. This section details the Compact, other U.S. funding, and international donors, and begins to map the funding to project examples and overall energy-related efforts.

\subsection{U.S. Financial Support}

The DOI has recently funded several energy-related initiatives, including a 2009 payment to the Pacific Power Association to study MEC's generation and distribution systems to identify and quantify losses and opportunities to reduce those losses. Additionally, a DOI grant of $\$ 627,000$ supported the initial phase of a very successful program to convert residential customers on Majuro to prepay meters. Funds were dispersed over three years, starting in 2010.

In addition to funding levels established by the Compact, Compact-enabling legislation made the U.S. Department of Agriculture (USDA) Rural Electrification Administration programs available to the RMI. Financial aid from USDA's Rural Utilities Service (RUS) program was used to build a 12.8-MW power plant for MEC on Majuro. The plant was commissioned in 1999 and almost doubled MEC's generation capacity, adding much needed reserve margins. The loan to MEC was $\$ 12.5$ million to be paid back at $6.9 \%$ over 20 years. In addition to the loan, RUS performed feasibility studies and provided construction oversight. A U.S. Government Accountability Office (GAO) report indicates that the added generation capacity (and perhaps subsequent improved reliability) had important socioeconomic development benefits: "the number of private electricity consumers rose by $11 \%$ and the number of new business users rose by $34 \%$ between 1997 and 1999." ${ }^{41}$ A press article reports that MEC received a two-year deferment on this loan and a $\$ 2.3$ million grant to overhaul a 6-MW generator in need of repairs. ${ }^{42}$ Other references suggest that MEC is having difficulty repaying the loan due to the extent of its financial troubles.

The USDA also provided funding to Island Eco, a privately owned renewable energy equipment and installation company on Majuro. The funding was directed toward providing subsidized freezers to communities on several outer atolls. The freezers are used by the communities for necessities, such as food and medicine. Training manuals and videos were also developed to add to the training and education aspect of the project. ${ }^{43}$

\subsection{International Donor Activities}

International funding is a large part of the RMI's annual budget, and a significant portion of this funding is targeted at the energy sector. A 2012 United Nations Development Programme (UNDP) report ${ }^{24}$ indicates that, since 2008 , over $\$ 13.5$ million in assistance has been provided to support the RMI's renewable energy and energy efficiency sector. Parties providing this assistance, other than the United States, include AusAID, the European Commission, the UNDP, the ADB, the Japan International Cooperation Agency, the Embassy of China (Taiwan), the Global Environment Facility, and the World Bank.

\footnotetext{
${ }^{41}$ Foreign Assistance Effectiveness and Accountability Problems Common in U.S. Programs to Assist Two Micronesian Nations. Washington, D.C.: U.S. Government Accountability Office, January 2002.

42 Johnson, G. "Grant Sought For Marshall Islands Solar Power System.” Pacific Islands Development Program/East-West Center, 2012. http://pidp.eastwestcenter.org/pireport/2012/November/11-20-12.htm.

${ }^{43}$ Nathan, N. Meeting. Island Eco, Republic of the Marshall Islands, Dec. 4, 2012.
} 


\subsubsection{Australian Agency for International Development}

Through the Australia/Republic of the Marshall Islands Partnership for Development (signed in August 2010), the two countries work together to support the RMI's development, especially in areas where help is most needed. The partnership commits the RMI to provide sound laws, policies, and public services for its citizens, and to effectively and transparently manage development resources. It commits Australia to better target aid, give good technical advice, and to work closely with the RMI government to deliver assistance. From 2010 to 2012, AusAID invested \$15.9 million in total official development assistance (ODA), with about $\$ 6.75$ million in 2012 . Typically, about $15 \%-20 \%$ of the total funds go toward sustainable economic development. The investments contribute to important development projects, including the following energy- and infrastructure-related projects:

- Development of a National Energy Policy and Energy Roadmap.

- Street lights on Majuro and Ebeye were replaced in 2010 with more energy- and cost-efficient bulbs. This has resulted in a 70\% reduction in energy use for street lighting.

- Installation of more than 1,900 electricity meters in Majuro and revision of fuel supply arrangements, resulting in monthly savings of $\$ 1.3$ million.

- Increased water security on Kwajalein Atoll through the provision of household water catchment tanks to 380 households (approximately 4,000 people).

- Technical assistance in the water sector, contributing to the development of a draft National Water and Sanitation Policy for the Marshall Islands, and resulting in a new accounting and billing system that has increased revenue.

AusAID expects to provide an additional \$7.3 million in total ODA to RMI in 2013-2014. AusAID has committed to ongoing support for the bilateral energy cost reduction and energy efficiency improvement program. $^{44}$

Part of AusAID's support also includes providing a technical expert to work within the energy office.

\subsubsection{European Commission-EuropeAid}

EuropeAid has provided funding to the RMI as part of both the $9^{\text {th }}$ and $10^{\text {th }}$ European Development Fund (EDF) programs. The EDF is the main instrument for providing community aid for development cooperation in the African, Caribbean, and Pacific states, and the overseas countries and territories. The EDF is funded by European Union member states, is subject to its own financial rules, and is managed by a specific committee. The $9^{\text {th }}$ EDF covered 2000 to 2007, and the $10^{\text {th }}$ EDF covers 2008-2013. ${ }^{45^{2}}$ During the $9^{\text {th }}$ EDF period, funding totaled $€ 12.38$ million and was divided among five Pacific island countries. Through this development aid, several renewable energy and energy efficiency projects were implemented including: ${ }^{46}$

- Solar home system installations on Ailinglaplap $(€ 1,350,000)$

- Off-grid solar PV systems for six primary schools $(€ 800,000)$

- Drafting of a national energy policy and energy action plan $(€ 100,000)$

\footnotetext{
44 "The Republic of the Marshall Islands." Australian Government AusAID, 2013.

http://www.ausaid.gov.au/countries/pacific/rmi/Pages/home.aspx.

45 “European Development Fund (EDF)." Europa, European Union, 2007.

http://europa.eu/legislation_summaries/development/overseas countries territories/r12102 en.htm.

46 "REP-5 Support to the Energy Sector in Five ACP Pacific Island Countries." European Union, 2010. www.rep5.eu/Project_Countries/RMI.
} 
Following the $9^{\text {th }}$ EDF program, the RMI, along with Palau and the Federated States of Micronesia, pooled the combined total of $€ 14.4$ million of EDF 10 resources and formed the North Pacific African, Caribbean, and Pacific group of nations Renewable Energy and Energy Efficiency Project. ${ }^{47}$ The $10^{\text {th }}$ EDF considers "cross-cutting issues, in particular climate change and environmental sustainability, but also democracy, good governance, human rights, the rights of children and indigenous people, gender equality and the fight against HIV/AIDS. The program allocates $€ 5.8$ million to the Marshall Islands to address these priorities." 48

\subsubsection{United Nations Development Programme}

The UNDP is the UN's global development network. It operates in 177 countries and territories, and works with governments and people on their own solutions to global and national development challenges. ${ }^{49}$ From 2008 to 2012, funding allocated to the RMI totaled \$468,600. UNDP also worked with the RMI government to seek financing partnerships in hopes of mobilizing an additional \$2.7 million. ${ }^{50}$ UNDP implemented three projects in the RMI, targeting poverty reduction and millennium development goals; good governance and human rights; and environment and sustainable management. Under the environment and sustainable management project, UNDP focused efforts on renewable energy technologies through the Action for Development of Marshall Islands Renewable Energies (ADMIRE). According to UNDP, this project aims to "remove barriers to RMI's efforts to reduce greenhouse gas emissions through the widespread use of feasible renewable energy technologies (RETs), to establish a national policy and program for renewable energy with the context of a national energy policy, and create a conducive environment for investments in RETs on the power generation at the utility level and enhance socio-economic growth in the country's rural areas through increased application of household- and village-level RET applications." ${ }^{51}$

\subsubsection{Asian Development Bank}

The ADB's overall mission is to realize poverty reduction in Asia and the Pacific nations. ADB incorporates multiple strategies to achieve this goal, including investment in infrastructure, health services, financial and public administration services, and assisting nations prepare for the impact of climate change by sustainable management of their natural resources. The main mechanisms for assistance are loans, grants, policy dialogue, technical assistance and equity investments. ${ }^{52}$ According to ADB:

Since partnering with the RMI, ADB has approved 14 loans for $\$ 92.63$ million, 48 technical assistance projects for $\$ 21.11$ million, and one grant for $\$ 1.76$ million. ADB loans have supported development of the education, fisheries, health, water, and transport sectors, and assisted public sector reform and structural adjustment. The technical assistance program has also covered a wide range of sectors and issues, including capacity building in development banking, tourism management, environmental protection, and the formulation of economic

\footnotetext{
47 "NORTHREP." Secretariat of the Pacific Community, 2013. www.spc.int/northrep/.

48 "Development and Cooperation-EuroAid." European Commission, 2012. http://ec.europa.eu/europeaid/where/acp/country-cooperation/marshall-islands/marshall-islands en.htm.

49 “The Global Mandate.” United Nations Development Programme, 2013. Accessed May 31, 2013: http://www.undp.org.fj/index.php?option=com_content\&task=view\&id=22\&Itemid=59.

${ }^{50}$ Country Programme Action Plan (CPAP) 2008-2012 between the Government of the Marshall Islands and United Nations Development Programme Fiji Multi-Country Office. Government of the Republic of the Marshall Islands and United Nations Development Programme Fiji Multi-Country Office, undated. Accessed May 31, 2013: http://www.undp.org.fj/pdf/CPAP/MARSHALL\%20ISLANDS\%20CPAP\%202008-2012_SIGNED.pdf.

51 “UNDP Projects in RMI." United Nations Development Programme, 2013. Accessed May 31, 2013: www.undp.org.fj/index.php?option $=$ com_content\&task=view\&id=88\&Itemid $=130$.

52 “Overview.” Asian Development Bank, 2013. Accessed May 31, 2013: www.adb.org/about/overview.
} 
policy. The program has also helped privatize state-owned enterprises, develop the private sector, and reform the civil service. ${ }^{53}$

In 2012, ADB funding totaled $\$ 5.23$ million. One of the main energy projects funded by ADB through a grant was the Improved Energy Supply for Poor Households Project. Clean energy has also become one of ADB's highest priorities. ADB anticipates achieving total target lending amounts of \$2 billion for clean energy programs in 2013 . This could potentially be a major source of funding for the RMI. ${ }^{54}$

\subsubsection{Japan International Cooperation Agency}

The Japan International Cooperation Agency (JICA) provides financial support for sustainable economic development. Their main tenet is to encourage all people to recognize the development issues they face, participate in addressing them, and enjoy the success of such endeavors. ${ }^{55} \mathrm{JICA}$ has provided assistance to the RMI with a focus on controlling the generation of waste and maintaining lifeline subsidies. The largest PV system in the RMI, the 205-kW PV system on the Majuro Public Hospital, was developed with JICA funding. ${ }^{56}$ In 2011, JICA provided the RMI with \$3.58 million in grant aid and another \$2.63 million in technical cooperation, for a total of $\$ 6.21$ million. $^{57}$

\subsubsection{Embassy of the Republic of China (Taiwan)}

The Embassy of the Republic of China (Taiwan) is located on Majuro in the RMI. The embassy is committed to assisting the RMI with accomplishing progressive and sustainable development. The embassy provides grants that are released as RMI provides reports on the progress of grant-related projects. Grants have funded, among other projects, residential solar PV systems on outer islands and solar street lights throughout the RMI. Grants are approximately $\$ 2.75$ million per quarter, although the total number of grants given to date could not be determined by the NREL assessment team. The most recent grant identified was in the third quarter of 2011, and it prioritized \$217,000 toward the National Energy Support Account. ${ }^{58}$

\subsubsection{Global Environment Facility}

The Global Environment Facility (GEF) unites 183 countries in partnership with international institutions, civil society organizations, and the private sector to address global environmental issues while supporting national sustainable development initiatives. The GEF provides grants for projects related to biodiversity, climate change, international waters, land degradation, the ozone layer, and persistent organic pollutants. ${ }^{59}$

The RMI received GEF grants totaling:

- $\$ 1,971,400$ leveraged to $\$ 1,777,800$ in cofinancing resources for five national projects

- Participated in 16 regional and global projects totaling $\$ 99,295,966$ that leveraged $\$ 305,458,516$ in cofinancing resources

\footnotetext{
${ }^{53}$ Asian Development Bank \& Marshall Islands Fact Sheet. Asian Development Bank, 2012. Accessed May 31, 2013: www.adb.org/sites/default/files/pub/2013/RMI.pdf.

54 “Clean Energy Program.” Asian Development Bank, 2013. www.adb.org/sectors/energy/programs/clean-energy-program.

55 "Mission Statement." Japan International Cooperation Agency, undated. www.jica.go.jp/english/about/mission/index.html.

56 "Project for the Introduction of Clean Energy by Solar Electricity Generation System." Office of the President, Republic of Marshall Islands, Dec. 16, 2009. www.rmigovernment.org/news detail.jsp?docid=327.

57 "Activities in Marshall Islands." Japan International Cooperation Agency, undated. www.jica.go.jp/marshall/english/activities/index.html.

58 “Taiwan Presents RMI with \$2.75 million Yearly Grant.” Pacific Islands Development Program/East-West Center, January 2012. http://pidp.eastwestcenter.org/pireport/2012/January/01-20-rl2.htm.

59 "What is the GEF." (2013). Global Environment Facility: http://www.thegef.org/gef/whatisgef.
} 
- Part of the subregional GEF Small Grants Programme

○ Received financial support totaling $\$ 1,969,670$

○ Leveraged $\$ 1,713,276$ in co-financing

- Executed 46 projects by civil society and community-based organizations for the entire subregional program.

During the current GEF-5 replenishment period (July 2010 to June 2014), RMI received an indicative allocation to formulate and execute projects for:

- $\$ 2,020,000$ in biodiversity

- $\$ 2,000,000$ in climate change

- $\$ 500,000$ in land degradation. ${ }^{60}$

Two wind resource measurement stations currently installed on the islands of Jaluit and Wotje were funded by GEF. ${ }^{61}$

GEF also works with UNDP to administer the ADMIRE project. The project objective is geared toward the removal of barriers that exist in successful utilization of renewable energy resources in the country and the subsequent application of those technologies. ${ }^{62}$

\subsubsection{World Bank}

The World Bank's mission is to reduce poverty and support development. The World Bank is composed of two institutions managed by 188 member countries: the International Bank for Reconstruction and Development and the International Development Association. The World Bank provides financial assistance to developing countries in the form of low-interest loans, interest-free credits, and grants. ${ }^{63}$ In 2013, the World Bank launched its first Country Partnership Strategy with the RMI government. The first project is a $\$ 3$ million effort to help reform the telecommunications sector and boost access to mobile phones and the internet. ${ }^{64}$

Figures 6 and 7 represent the breakdown of the RMI's international donor contributions in U.S. dollars with approximate totals. Figure 6 excludes Compact funding. Figure 7 includes Compact funding.

\footnotetext{
${ }^{60}$ The Marshall Islands and the GEF. The Global Environment Facility, June 2012. www.thegef.org/gef/sites/thegef.org/files/publication/Marshall $\% 20$ Islands $\% 20-\% 20$ Fact $\% 20$ Sheet $\% 20$ $\% 20$ From $\% 20$ Rawleston.pdf.

${ }^{61}$ Learned from Ministry of Resources and Development personnel during the assessment trip.

${ }^{62}$ The Marshall Islands and the GEF. The Global Environment Facility, June 2012. www.thegef.org/gef/sites/thegef.org/files/publication/Marshall $\% 20$ Islands $\% 20-\% 20$ Fact $\% 20$ Sheet $\% 20$ $\% 20$ From $\% 20$ Rawleston.pdf.

63 "What We Do." The World Bank, 2012. http://web.worldbank.org/WBSITE/EXTERNAL/EXTABOUTUS/0, contentMDK:20103838 menuPK:1696997 pagePK:51 123644 piPK:329829 theSitePK:29708,00.html.

64 "World Bank and Marshall Islands launch new strategy to strengthen partnership.” The World Bank, 2013. www.worldbank.org/en/news/press-release/2013/03/19/world-bank-marshall-islands-launch-new-strategy-to-strengthenpartnership.
} 


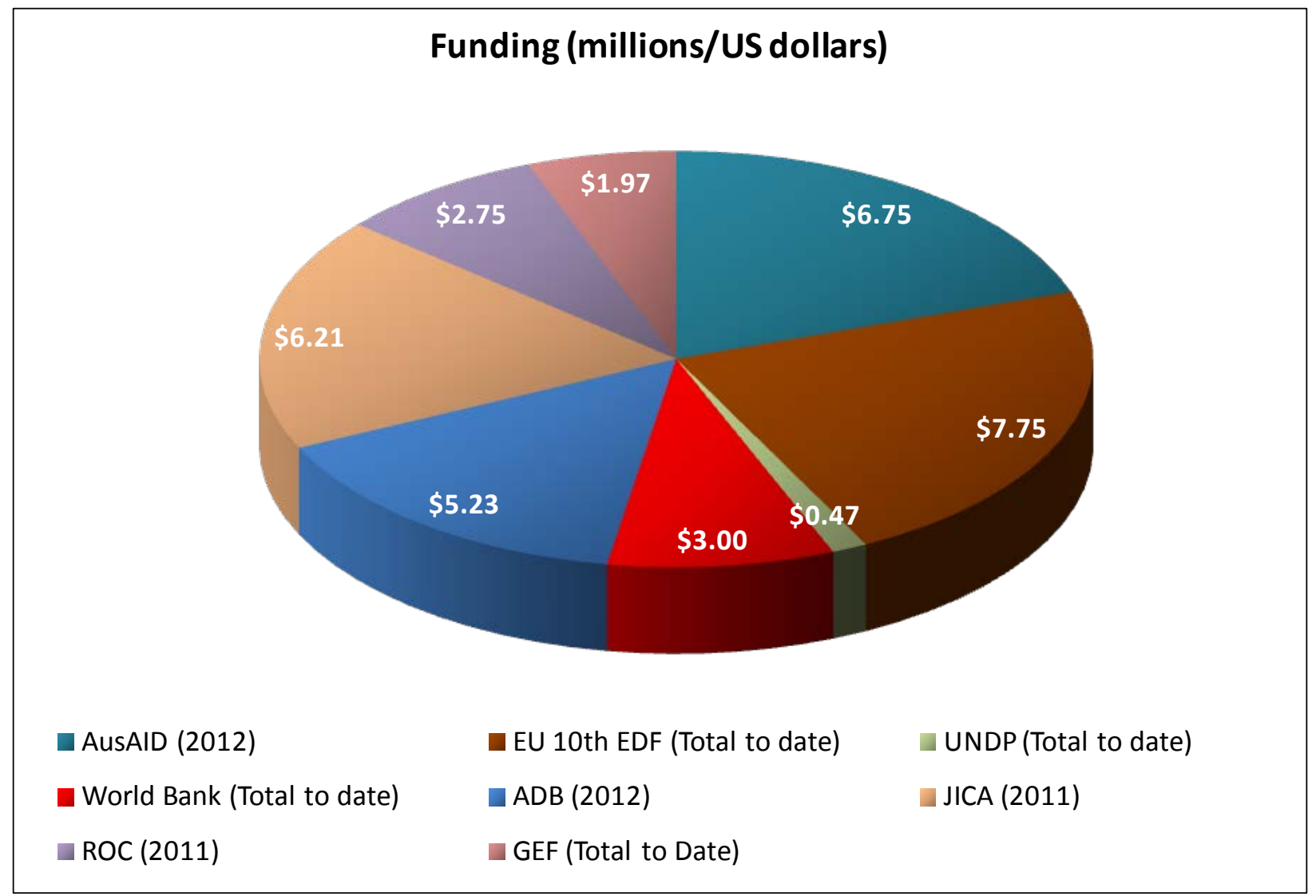

Figure 6. International donor funds (excluding the Compact)

\section{Funding (millions/US dollars)}

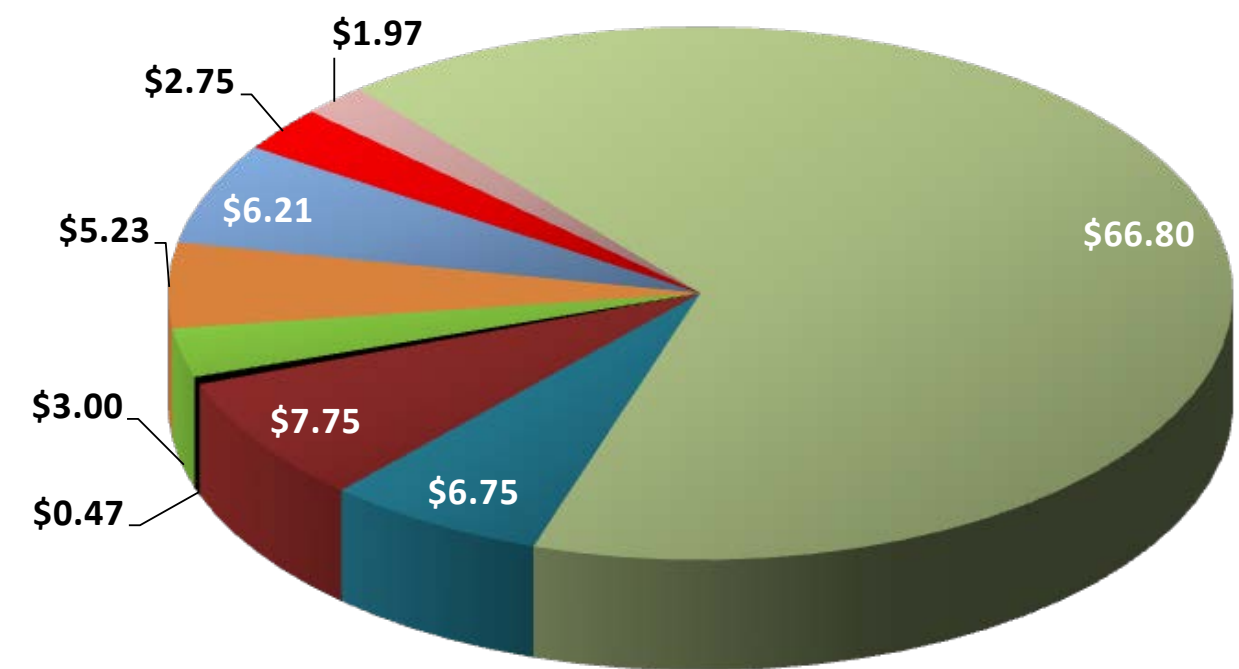

US Compact (2012)

- UNDP (Total to date)

JICA (2011)
AusAID (2012)

World Bank (Total to date)

ROC (2011)
EU 10th EDF (Total to date)

ADB (2012)

GEF (Total to Date)

Figure 7. International donor funds (including the Compact) 


\section{Energy Efficiency and Renewable Energy Opportunities}

High energy costs, isolation from large electrical grids, and access to local indigenous renewable resources are driving small island communities to explore alternatives to imported fossil fuels. Many island communities have set ambitious goals for reducing fossil fuel usage and increasing renewable energy generation.

In the RMI, the goals in the NEPEAP include 20\% renewable energy generation by 2020, and improved efficiencies in generation, distribution, and end-user equipment. In addition to the national government's goals, system reliability and the cost of energy are high-priority issues to RMI citizens and businesses, which are bottoms-up drivers for energy sector changes.

There are many energy efficiency and renewable energy opportunities for the RMI. However, there is no single opportunity or simple means to reach the NEPEAP's $20 \%$ renewable energy by 2020 goal. The seven years remaining until 2020 are likely to be insufficient to accomplish the full suite of necessary projects. Energy sector transformation will require significant investment in infrastructure. Political and regulatory bodies will need to adjust to facilitate change, and the electrical system operators will need to develop the necessary institutional capacity to manage more complex systems.

This section outlines opportunities identified from the initial assessment and quantifies their technical potential over a 20-year time horizon (2012 to 2032) to change total power-sector fossil-fuel energy consumption and accomplish national goals as outlined in the NEPEAP. This 20 -year outlook allows sufficient time for institutional adjustments and step-by-step infrastructure investments.

This analysis indicates the technical potential only. It is intended to provide a sense of scale of each opportunity and is exploratory. It is based on the works of others and information gathered during the assessment trip. This is not an economic analysis. Costs and benefits of individual projects are dependent on many local and global factors. Each technology opportunity requires careful analysis of supply chains, availability of capital, risks, and local technical and nontechnical factors, including renewable resource availability, site access, permitting, and availability of skilled labor, both for construction and operation, and the ability for projects to collect necessary revenues.

The results presented provide one possible scenario to achieve significant fossil fuel reductions. The actual path to 2032 and final power sector profile will certainly be different than this picture and will depend on choices made along the way, technological advancements, economics, and evolution of RMI's legal, regulatory, and policy environment.

\subsection{Methodology}

The scenario presented here was developed through the following primary sources:

- Site visit to RMI, including Majuro, Ebeye, and Jaluit, where the assessment team consulted with private and government stakeholders, and visited power plants, industrial sites, and commercial buildings

- Review of the extensive body of prior work developed by the RMI government and for the RMI by multiple regional partners, NGOs, international aid agencies, and other national governments

- Consultation with individuals in the U.S. government, representing the DOI, the Department of State, the DOD, and others

- A screening for technical potential based on available area, indigenous renewable resources, and local power system limitations based on general rules of thumb for the quantity of renewable energy that can be placed on electrical grids that use primarily diesel generators 
- Application of a model that allowed a basic assessment of the relative potential impact of the various energy efficiency and renewable energy opportunities.

The continued evolution of technologies, costs, and policies will continue to influence the path of change in the RMI's power sector. This analysis presents a "what-if" approach based on limited scope and data to describe the potential scale and impact of each available opportunity. Refined analyses for these opportunities are needed before investment and policy decisions are made.

\subsection{Wedge Model Results}

Summary results of the analysis are presented here, while detailed discussions follow in subsequent sections. Figures 8 through 12 show results of the what-if analysis using 2012 as a benchmark and assuming zero growth in energy consumption.

Figure 8 shows the potential contribution of energy efficiency and renewable energy by 2032 in units of barrels of oil equivalent (BOE). The BOE metric assumes that \#2 diesel is used as the power plant fuel, and the analysis is based on current power plant efficiencies. The baseline is established using electricity production data for Majuro, Ebeye, and Jaluit. Data for other districts were not provided; however, these three districts account for approximately $99 \%$ of total central plant generation in the RMI and are sufficient for the fidelity required in this report.

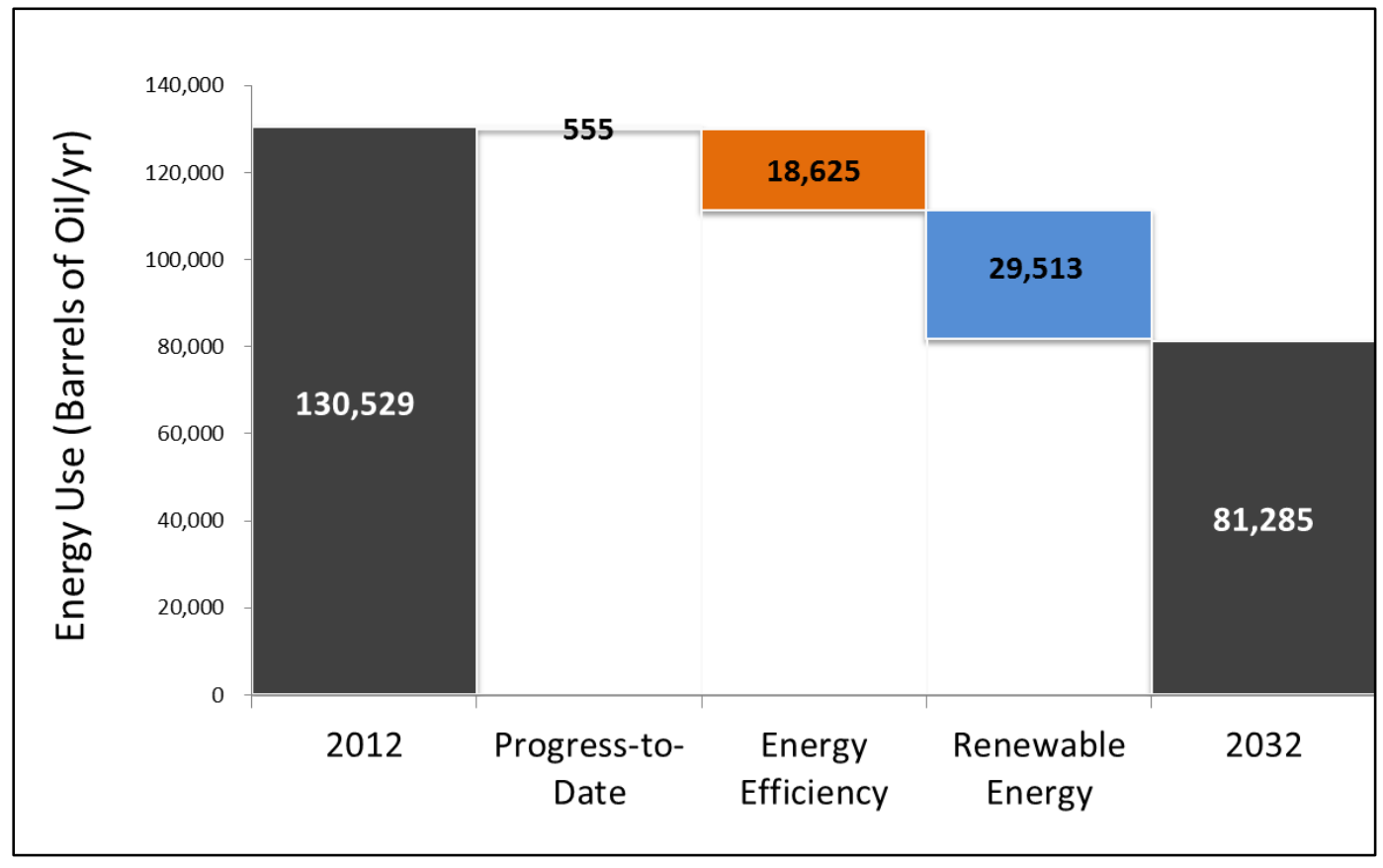

Figure 8. Waterfall presentation of the wedge analysis

Figure 9 shows the impact of the analysis scenario in year 2032 relative to the 2012 baseline: a 17\% reduction in power-sector fossil-fuel usage as a consequence of energy efficiency measures and an additional $23 \%$ reduction from renewable energy technologies. 


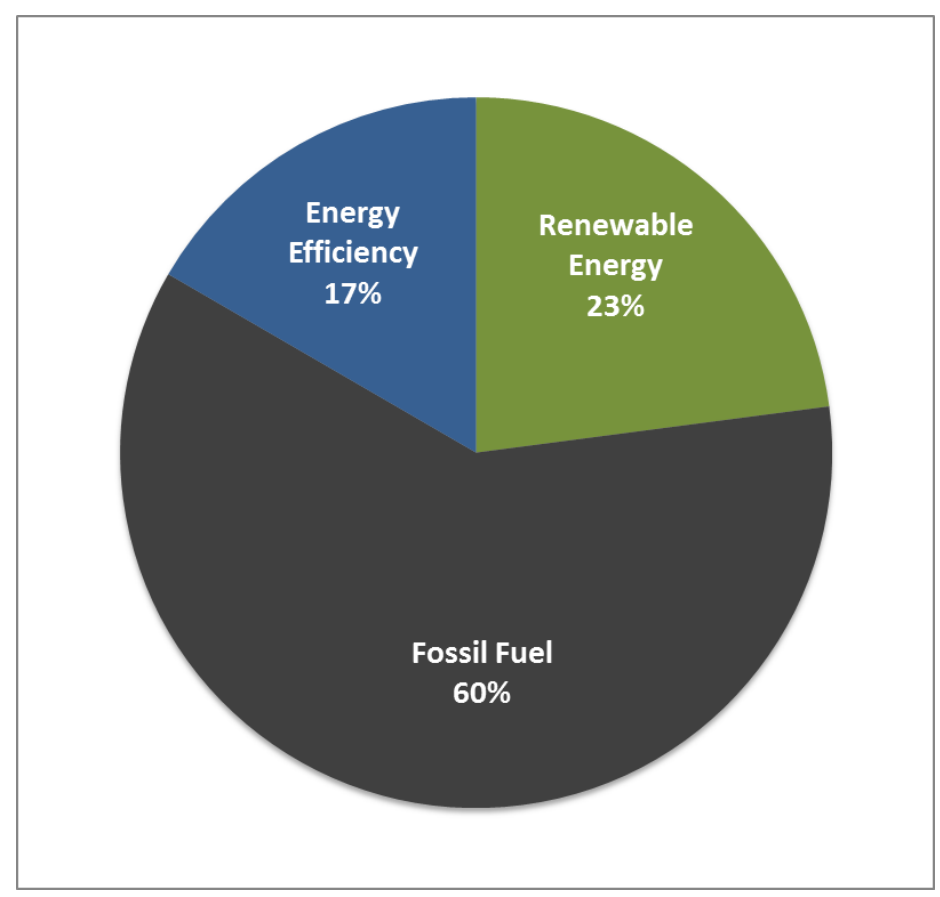

Figure 9. The RMI electricity sector in 2032 relative to the 2012 baseline

Figure 10 is a timeline that shows the projected impact of renewable energy (RE) and energy efficiency (EE) measures on fossil fuel consumption from 2012 to 2032 based on the staged technology deployment assumptions in the analysis model. The purpose of this "wedge" analysis is to show, in graphical form, the likely impact of potential measures taken to reduce the use of fossil fuels. After an alternative technology or policy is implemented, it typically creates an irregular-looking wedge on a timeline graph; hence the name given to this type of analysis. The thin orange band in the figure is progress to date, attributed to the fuel offsets achieved by the existing $262 \mathrm{~kW} \mathrm{DC}$ (combined capacity) of grid-tied PV systems installed at the College of the Marshall Islands and the Majuro Public Hospital. 


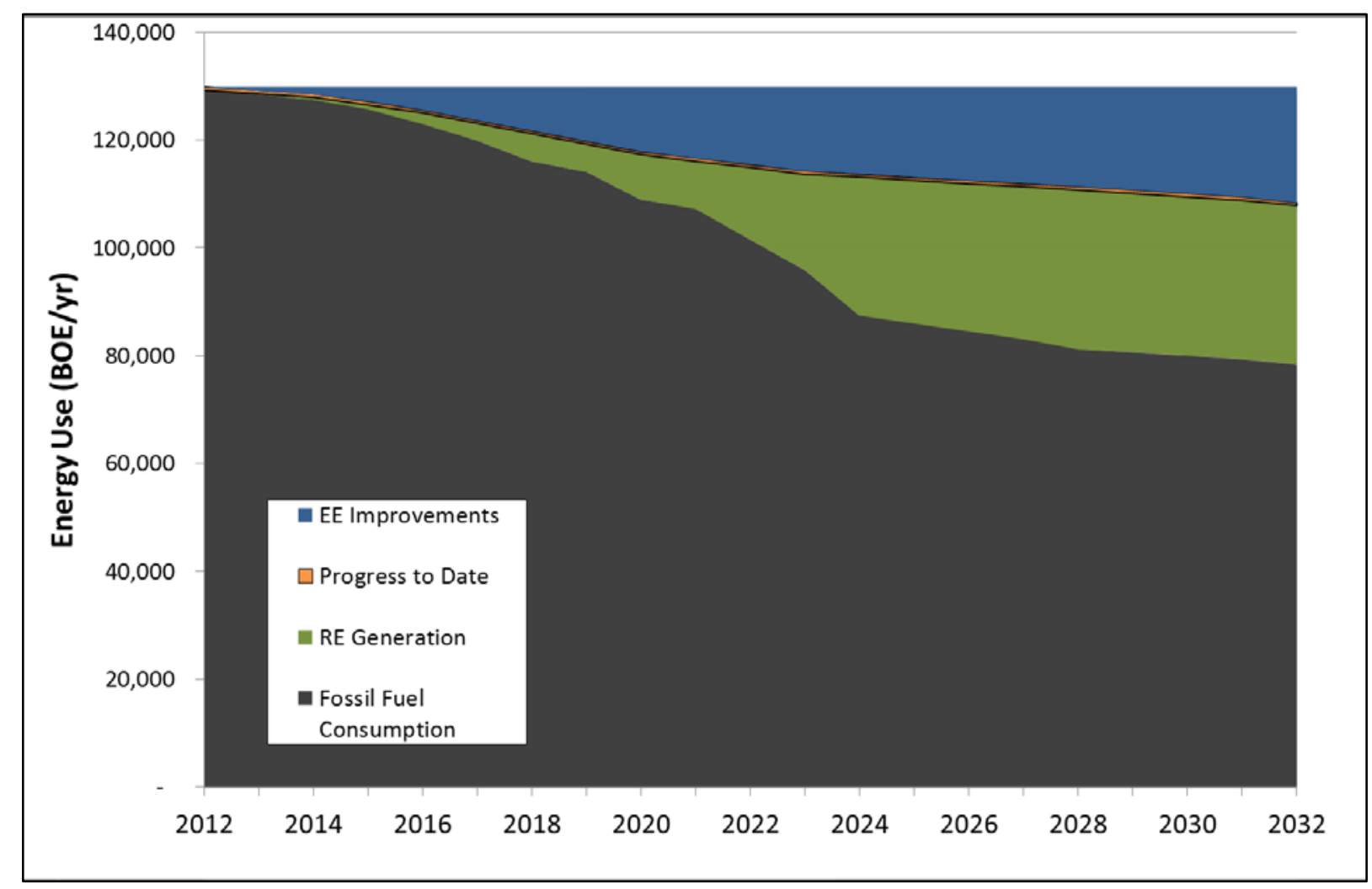

Figure 10. Analysis model scenario wedges from 2012 to 2032

Figure 11 presents the model results with the energy efficiency wedge removed to show power sector generation only. Results are normalized to show the percentage of energy generation provided by both oil and renewable energy. This is done to compare the wedge analysis under this scenario against the NEP's 20\% renewable energy by 2020 goal, which describes how much of the electricity produced by 2020 needs to be supplied by renewable energy technologies. The RE energy is stacked from the bottom to allow easy comparison. The NEP goal is aggressive. Considering the current rate of progress, it is unlikely this goal can be met by 2020 . It will be difficult to accomplish without starting development of multiple large capital projects immediately. 


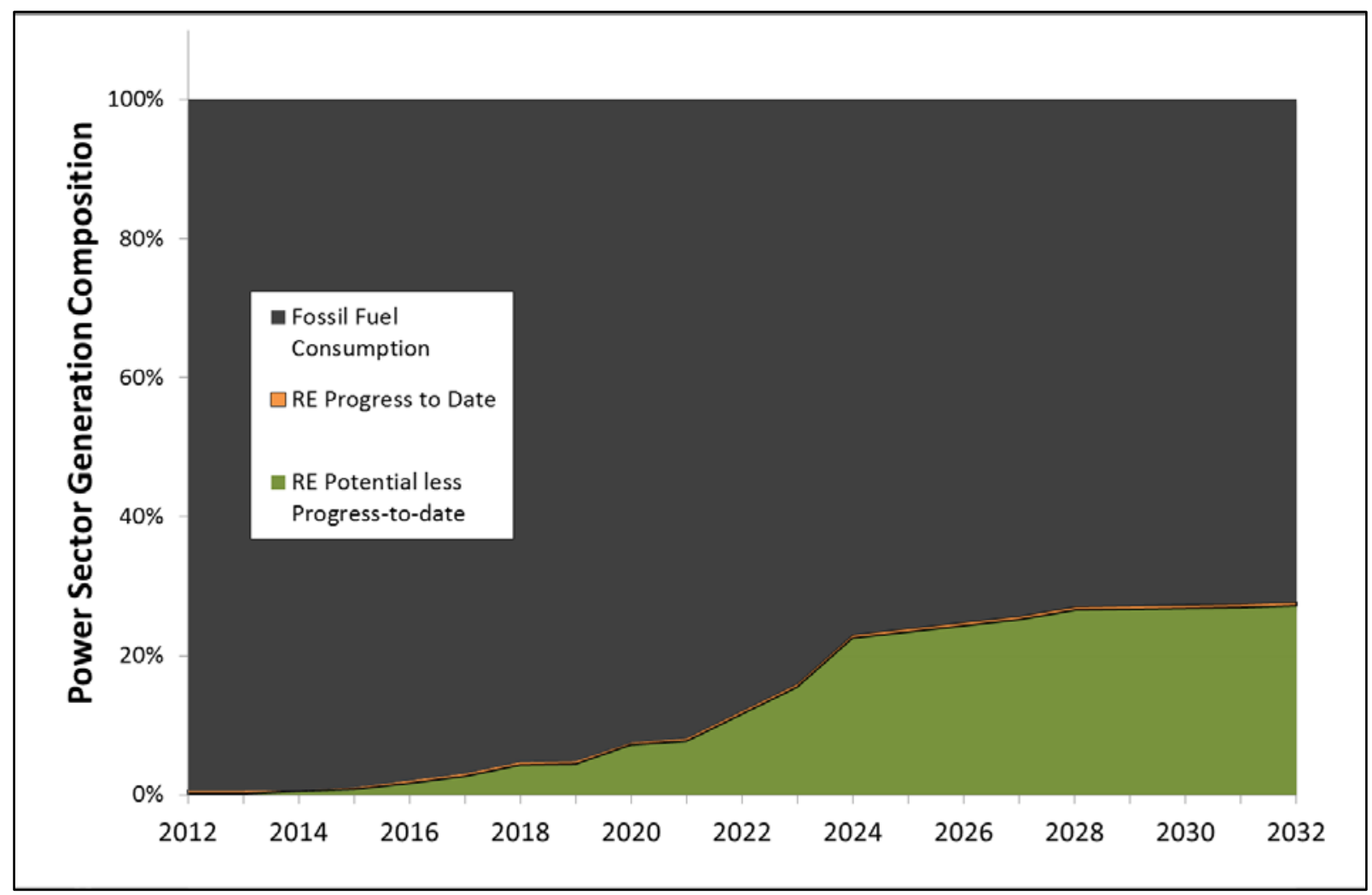

Figure 11. Analysis model power generation profile from 2012 to 2032

Figure 12 splits out the individual technologies that make up the RE wedge in Figure 11. The vertical axis is clipped at $30 \%$ to show more clearly the individual technologies.

Figure 12 shows that the NEP renewable energy goal cannot be reasonably accomplished with PV and wind technologies alone, due primarily to technical limits imposed by the variable nature of their output, unless significant investments were made in energy storage batteries and electrical system upgrades. The $20 \%$ renewable energy goal is achievable, but it will likely take longer than the next seven years to realize. The existing $262 \mathrm{~kW}$ of PV on Majuro is offsetting approximately $0.6 \%$ of the total energy generation on Majuro in 2012 and is about $0.5 \%$ of the total generation across all three islands in the 2032 scenario. 


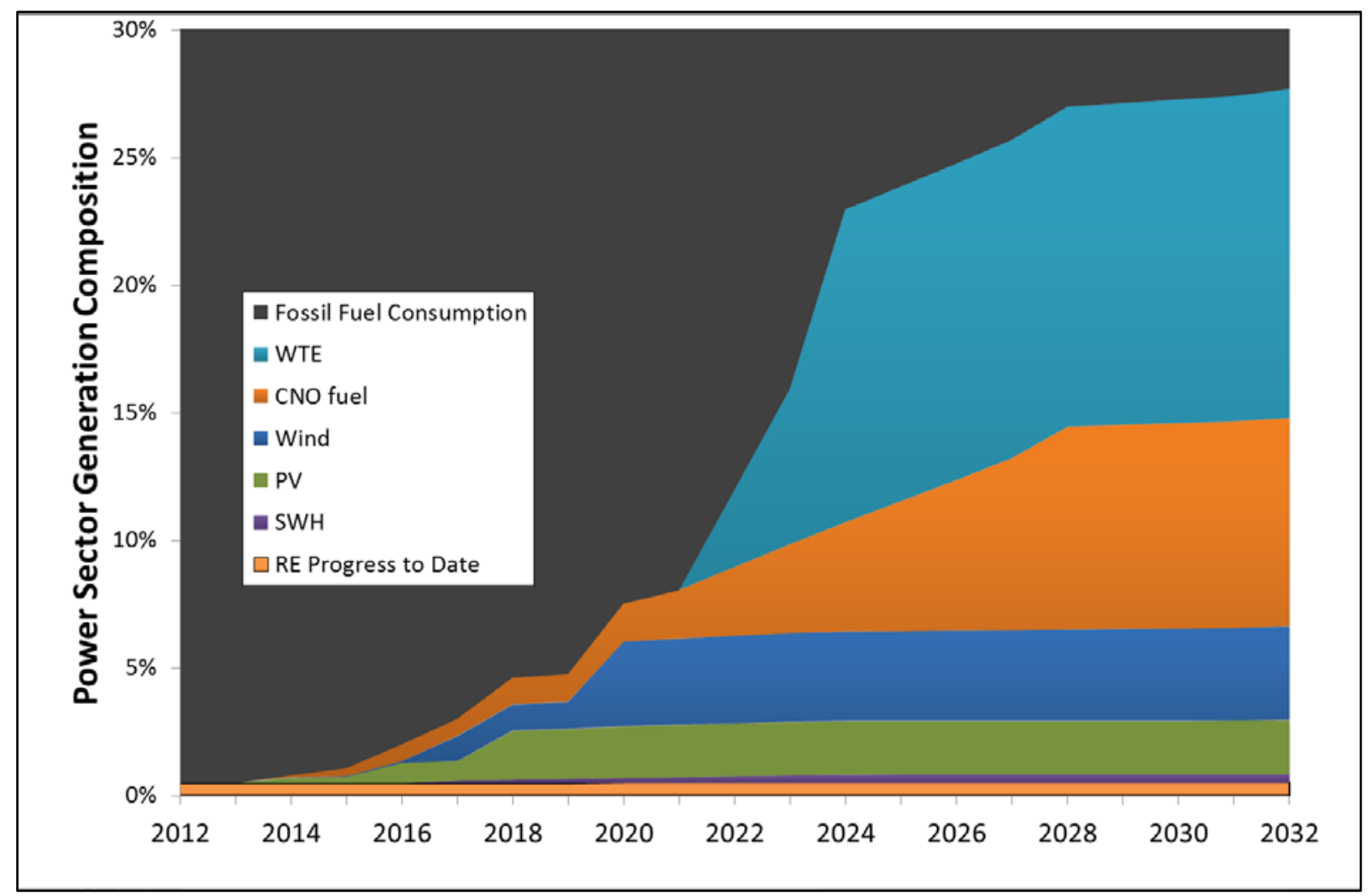

Figure 12. Analysis model renewable energy profiles from 2012 to 2032 (the vertical axis scale is cut at $30 \%$ )

Twenty percent renewable energy could be accomplished by constructing a 1.2-MW waste-to-energy (WTE) plant (12.9\% contribution) and diverting approximately $50 \%$ of the locally produced coconut oil (CNO) from export to the local power sector for blending with diesel fuel (8.2\% contribution). Both of these resources are limited by the amount of feedstock available, so reduction in total energy use through any gains in energy efficiency will reduce total fossil fuel imports and proportionally increase the potential contribution from renewable sources. Each of these options is discussed in greater detail throughout the following sections of this report.

Under this scenario, potential fraction of electricity provided or offset by renewable energy would be $7 \%$ in 2020. This would require the installation of $1.3 \mathrm{MW}$ of PV, $1.3 \mathrm{MW}$ of wind, $1,400 \mathrm{ft}^{2}$ of solar water heating collectors, and 160,300 gallons/year of CNO being used in power plant generators.

The model demonstrates that $28 \%$ renewable energy is possible, after efficiency gains (presented in the next section), but the model allows more time than the NEP's 2020 time horizon to accommodate longer development cycles for waste-to-energy and conversion of diesel gensets for CNO blends. The $28 \%$ renewable scenario by 2030 includes the following mixture of renewable energy technologies and resources:

- $\quad 1.2 \mathrm{MW}$ waste-to-energy plant

- $1.35 \mathrm{MW}$ of PV

- $\quad$ 1.4 MW of wind

- $2,300 \mathrm{ft}^{2}$ of solar water heating collectors

- 800,000 gallons/year of CNO consumed in central power plants (24\% CNO and 76\% diesel). 
The current scenario lays out a path to achieve this by 2032. It could be possible to meet this level of renewable energy sooner, but the implementation of projects would need to be accelerated beyond typical project lead times-especially waste-to-energy and CNO.

\subsection{Energy Efficiency and Conservation}

For this scenario, the energy efficiency gains by 2032 are split into two broad areas:

- Power sector efficiency gains in generation and distribution

- Reduced energy use by utility customers through improvements in the efficiency of electricityconsuming equipment and building systems, and implementation of conservation programs.

Figure 13 shows the relative contribution of these areas to the overall reduction in total fossil fuel usage from today to 2032: a 9.3\% reduction in fossil fuel usage by improving utilities' generation and distribution, and $7.3 \%$ through customer-side improvements. This figure includes total fuel reduction from today's baseline. The figure shows the total fossil fuel usage can be reduced to $60.5 \%$ of today's consumption rates if strategies for efficiency (both on the supply side and demand side) and renewable energy technologies are employed. The renewable energy contribution in this figure is $22.9 \%$ reduction from today's baseline total diesel fuel use.

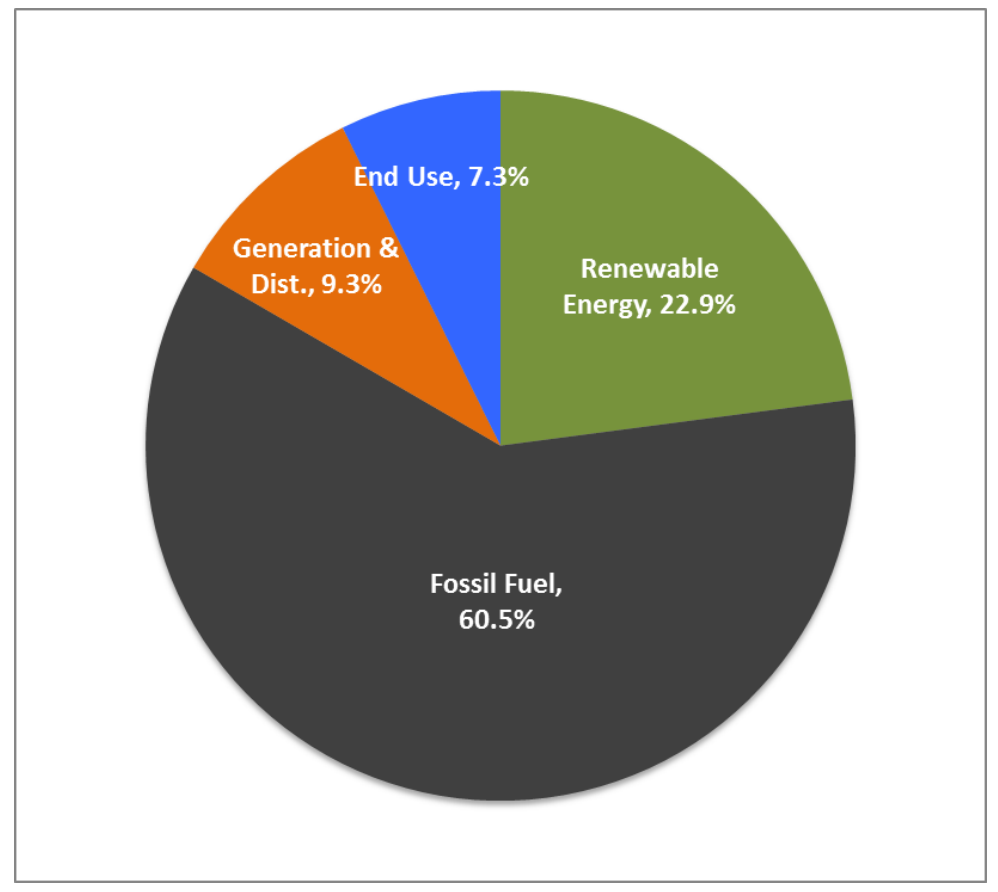

Figure 13. Energy efficiency reductions attributed to improvements in demand and supply from today's baseline

\subsubsection{Generation and Distribution Efficiency}

The assessment team visited power plants on Majuro, Ebeye, and Jaluit. MEC provided generation and fuel usage data for these power plants. The team developed estimates for possible efficiency improvements used in this scenario analysis from various reports and from information collected during the assessment trip.

The blended heat rate (indicator of generation efficiency) of the existing generators is within a reasonable range while station use (consumption within the power plants) and distribution system losses are high. Generation and distribution efficiency baselines and 2032 improvement assumptions are shown in Table 8 . This scenario assumes a modest $2.8 \%$ improvement in the generation heat rate while larger 
gains in station usage and technical distribution system losses are taken from a report ${ }^{65}$ for MEC. It is assumed these same results can be reasonably applied to Ebeye and Jaluit. The same reference indicates that nontechnical losses due to theft could be reduced by $5 \%$ with enhanced enforcement, and the NREL analysis assumes that half of that reduction (2.5\%) results in increased revenue to the utilities and half results in reduced total consumption (i.e., avoided generation).

Table 8. Generation and distribution system efficiency benchmarks and assumed improvements

\begin{tabular}{|l|r|r|r|}
\hline & 2012 Baseline & 2032 Projection & Improvement \\
\hline Generation Heat Rate (BTU/kWh) & 9769 & 9500 & $2.8 \%$ \\
\hline Station Use & $8.45 \%$ & $6.45 \%$ & $2.0 \%$ \\
\hline Technical Losses & $6.41 \%$ & $4.41 \%$ & $2.0 \%$ \\
\hline Nontechnical Losses & $11.35 \%$ & $6.35 \%$ & $2.5 \%$ \\
\hline Total Improvement & & & $9.3 \%$ \\
\hline
\end{tabular}

Source: Utility personnel at Marshalls Energy Company and Kwajalein Atoll Joint Utilities Resources

With these assumptions, the analysis shows a 9.3\% reduction in total fossil fuel usage could be achieved. This is equivalent to about $12,100 \mathrm{BOE}$ per year.

\subsubsection{Consumer Efficiency}

During the assessment visits to Majuro, Ebeye, and Jaluit, the NREL team visited a number of government and commercial buildings to conduct stakeholder meetings. In addition, the NREL team toured the Tobolar Copra Processing Authority plant and the Ebeye Hospital to conduct walk-through assessments. The tours did not include detailed energy audits but provided a high-level assessment of general age and condition of buildings, including windows and doors, lighting type, space cooling equipment, and other infrastructure.

Reasonable, but highly uncertain, estimates of energy reduction potential by sector are included in the wedge analysis and are qualitative only. More detailed audits are needed to improve the analysis.

However, the assessment visit indicated that there are considerable opportunities for electricity demand reductions that are likely to be cost-effective. Retro-commissioning and improved maintenance have very short payback periods, as do many types of lighting system upgrades and simple operational changes, such as using occupancy sensors and thermostat settings. Installing more-efficient cooling systems; improving insulation and seals around doors and windows; adding shade awnings to windows and entrance vestibules; and utilizing cool and/or green roof concepts are other measures that are inexpensive and are likely to reduce total island fuel usage. In the longer term, building codes that include energy performance requirements and appliance energy efficiency standards will provide gradual improvements in usage efficiency as the building and equipment stock turns over as a result of remodeling, new construction, and regular replacement of appliances at the end of their useful life.

For this analysis, NREL estimated likely energy efficiency improvements by making assumptions about how many utility customers could potentially engage in efficiency improvements in each sector, and to what extent those consumers are able to reduce their electricity consumption. These improvements are only rough estimates.

\footnotetext{
${ }^{65}$ Quantification of Energy Efficiency in the Utilities of the U.S. Affiliate States (excluding US Virgin Islands. Pacific Power Association, December 2010. http://www.ppa.org.fj/wp-content/uploads/2013/03/PPA-Consolidated-Report-onQuantification-of-Losses.pdf.
} 
Table 9. Electricity usage and end use efficiency gains by sector assumed in the analysis

\begin{tabular}{|l|c|c|c|}
\hline & $\begin{array}{c}\text { Assumed Energy } \\
\text { Usage by Sector }\end{array}$ & $\begin{array}{c}\text { Assumed Ultimate } \\
\text { Penetration }\end{array}$ & $\begin{array}{c}\text { Assumed Ultimate } \\
\text { Use Reduction }\end{array}$ \\
\hline Residential & $35 \%$ & $25 \%$ & $20 \%$ \\
\hline Commercial & $30 \%$ & $25 \%$ & $20 \%$ \\
\hline Government & $35 \%$ & $60 \%$ & $20 \%$ \\
\hline
\end{tabular}

Source: Utility personnel at Marshalls Energy Company and Kwajalein Atoll Joint Utilities Resources

The NEPEAP describes a policy requiring energy audits of government facilities, placing responsibility on government departments to develop investment plans for energy efficiency improvements in their facilities, and requiring department energy managers to be responsible for developing and implementing these plans. For this reason, efficiency improvement rates for the government sector buildings were set more aggressively in the analysis with the assumption that the government would execute these policies and enforce them. MEC did not provide data on the relative magnitude of energy used by each sector, so the numbers shown in Table 9 are rough estimates only.

With these penetration levels and energy usage reduction levels, the model projects that a $7.3 \%$ reduction in total fossil fuel usage as a result of end user upgrades is possible. This is equivalent to about 9,500 BOE per year.

Local stakeholders indicated there is currently a very limited market for building energy audits and energy upgrades and general maintenance is poor. External aid agencies have funded some lighting system programs but the RMI does not appear to have any significant local capacity in the energy efficiency sector. High technical qualifications for auditors and a small market are likely the two primary reasons. The assessment team was told there is only one energy auditor currently residing and working in the RMI. Further, demand for these services seems to be very low, possibly due to limited available capital for investment and low public awareness of the financial advantages of energy conservation.

\subsection{Renewable Energy}

To be considered in this scenario, the renewable energy technologies had to be both commercially proven and have sufficient access to resources in the RMI. The technologies that meet these criteria for the RMI are solar PV, SWH, wind power, waste-to-energy, and liquid biomass (coconut oil) used as power plant fuel. The estimated relative contribution of each technology in 2032 is shown in Figure 14. The wedge model analysis indicates the combined generation (from PV, wind, WTE, and CNO) and generation offsets (from SWH) for these technologies is $28 \%$ in 2032, or approximately $30,000 \mathrm{BOE}$ per year. 


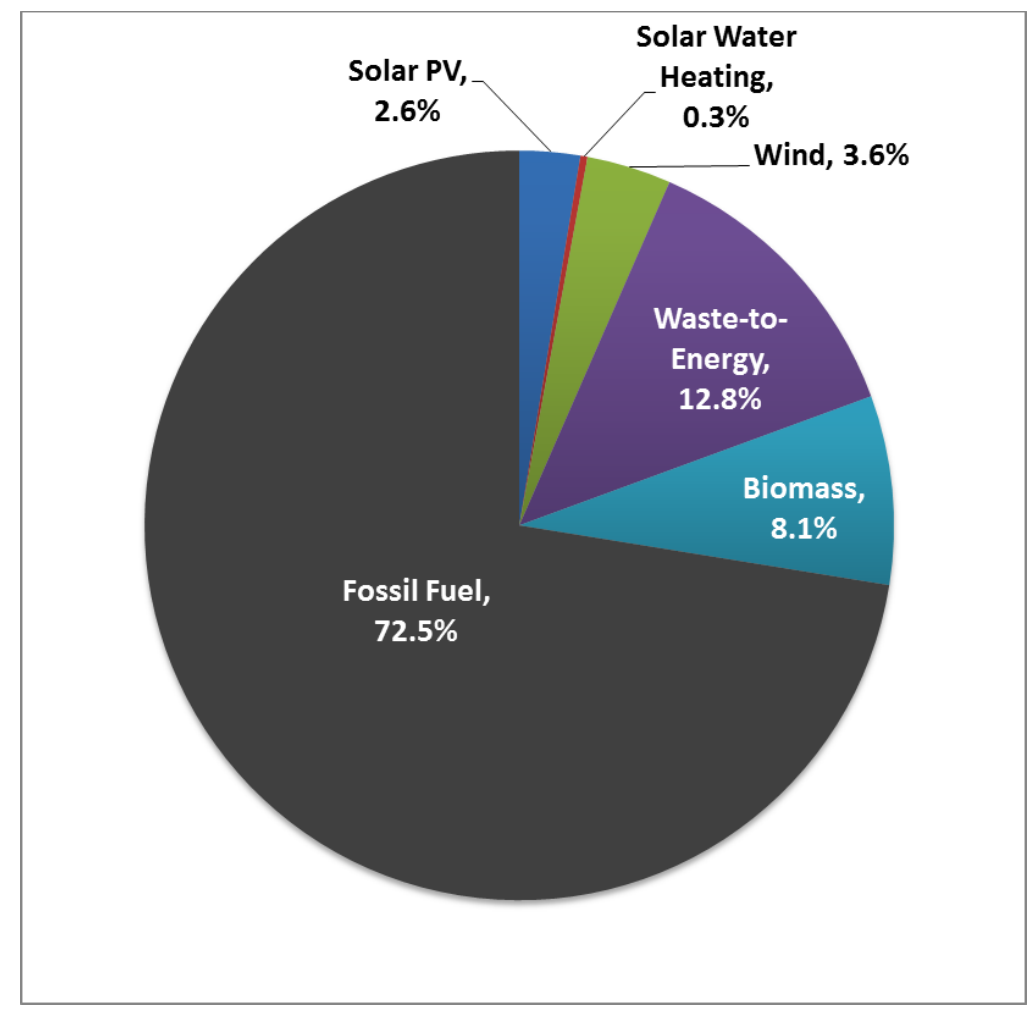

Figure 14. Contribution of each renewable energy technology to generation profile in 2032

In this analysis, PV and wind contribute a little over $6 \%$ of the total generation (energy in units of kilowatts). The total installed nameplate capacity of these two generation resources was limited to $30 \%$ combined contribution ${ }^{66}$ toward annual average demand in this analysis to acknowledge the technical limits set by potential system reliability and power quality issues. The actual limits may be higher or lower and would need to be determined by careful analysis of the existing generation and distribution systems, as well as the local solar and wind resource characteristics. Advanced energy storage and system control strategies would increase the potential contribution of PV and wind. A detailed systems integration study for each central grid system in the RMI would help to clarify these issues.

Energy efficiency gains are an important part of achieving this renewable energy goal. For example, the 1.2-MW WTE plant generates $8,300 \mathrm{MWh} /$ year in this model. This is $10.7 \%$ of the total $77,500 \mathrm{MWh}$ produced in central power plants on Majuro, Ebeye, and Jaluit in 2012. However, if the efficiency gains included in the previous section are accomplished, total annual demand of consumers will decrease and the same WTE plant would then meet $12.8 \%$ of the total. So the RE goal can be best accomplished by deploying both RE and improving electrical system and consumer efficiencies.

\subsubsection{Photovoltaics}

PV electricity generation is commercially available, economically competitive, and is well-suited to the RMI as it is a distributed generation technology that could be installed in small power clusters on existing rooftops and as ground-mounted systems on small areas of unoccupied or otherwise unusable land. PV-covered canopies over parking lots could also be installed for additional capacity potential at a modest price premium.

As described above, the RMI and MEC have experience on Majuro with grid-connected systems and with smaller off-grid battery-backed installations on the outer islands.

\footnotetext{
${ }^{66}$ That is, (nameplate capacity of wind power + nameplate capacity of PV)/(system annual average demand) $<=30 \%$.
} 
Off-grid systems can incorporate a combination of PV, wind, battery energy storage, and diesel backup generators to meet energy needs. The optimal choice of technologies depends on resource availability and load profiles at each site. Off-grid systems can be used in remote locations where the cost of extending power lines prohibits the system from being connected to the grid. Off-grid systems operate independently from the central electricity grid; grid-connected systems feed energy back into the grid.

The total amount of grid-connected PV is technically constrained by power quality and system stability requirements. This is due to PV's variable power output, which changes rapidly with passing clouds. When the percentage of total installed PV capacity is large relative to loads, the stability of individual feeder lines and the system as a whole is threatened unless energy storage and advanced system controls are used.

For this analysis, the total installed combined capacity on Majuro, Ebeye, and Jaluit is assumed to be $1.35 \mathrm{MW}$ by year 2032, which is equivalent to $15 \%$ of current annual average loads. It is assumed that this is accomplished without adding advanced system controls or costly battery systems. The actual amount of PV that could be added may be greater or less depending on electrical system design and load profiles. Adding energy storage and advanced demand-response technologies would make the system more robust and therefore allow higher levels of installed PV. The actual limits for the RMI will need to be established by careful analysis of the existing generation and distribution systems, as well as the local solar and wind resource characteristics. The estimated capacity factor used here is $15.5 \%$ based on PV modeling, as well as data collected on the College of the Marshall Islands' 57-kW DC system.

A summary of the impact of PV energy on business-as-usual (BAU) diesel generation is shown in Table 10. Energy generated and reported fuel savings assume that the PV system output degrades $0.5 \%$ per year and are reported for expected production in the year 2032. The timeline for implementation can certainly be accelerated should the RMI prioritize this effort.

Table 10. Photovoltaic systems size and potential impact by 2032

\begin{tabular}{|l|l|}
\hline Total Installed Capacity & $1.35 \mathrm{MW}$ \\
\hline Annual Energy Production & $1,689 \mathrm{MWh}$ \\
\hline Displaced Diesel & 2,845 barrels/year \\
\hline Fuel Reduction from BAU & $2.2 \%$ \\
\hline Electricity Contribution in Year 2032 & $2.6 \%$ \\
\hline
\end{tabular}

Source: Utility personnel at Marshalls Energy Company and Kwajalein Atoll Joint Utilities Resources

There is currently $262 \mathrm{~kW}$ DC of grid-tied PV on Majuro. The College of the Marshall Islands has a 57kW DC system installed on the customer's side of the meter and there is a $205 \mathrm{~kW}$-DC system on the Majuro Public Hospital connected to the utility's side of the meter. There may be other smaller systems, but the utility currently does not maintain records of such systems. These two systems contributed about $0.6 \%$ of the total energy generation on Majuro in 2012 and amount to about $0.5 \%$ of the total generation across all three islands in the 2032 scenario.

\subsubsection{Wind Power}

Wind power is a mature technology that is likely to be cost-effective in the RMI, and it should be included as a viable technology in sustainability and energy diversification plans. Properly sited installations have exposure to the prevailing wind direction, which can be accomplished everywhere in the RMI with sufficiently tall towers. 
Like PV, wind energy is an intermittent power source. Wind and PV can be complementary because solar intensity peaks at mid-day when winds are generally weak, and wind strength often peaks in the evenings and mornings. As described in the PV section above, limits on total installed capacity for wind (combined with PV) are applied in this analysis to acknowledge the constraints of power quality and reliability concerns. Here, the total installed combined capacity on Majuro, Ebeye, and Jaluit is assumed to be $1.4 \mathrm{MW}$ by year 2020 (the end year of the NEP goal), which is approximately $15 \%$ of annual average demand (capacity). With an aggressive pursuit of wind power, this timeline might be realized.

For wind resource estimates, two separate data sources were consulted: (1) a global climate data set based on internationally gathered data and predictive models, ${ }^{67}$ and (2) recently recorded wind resource data collected by the U.S. Army on Kwajalein Atoll. The two references present significantly differing conclusions as to the strength of the wind resource, and therefore, the generation potential and economics for a given wind turbine. The differences could be due to variations in wind resource from north to south across the RMI that is mentioned in a number of references or indicative of errors or uncertainty in either the measured data on Kwajalein or in the virtual modeled data.

The Energy Planning Division in the Ministry of Resource Development is currently conducting a wind and solar resource measurement project with funding provided by UNDP with technical support from the Palau Energy Office. ${ }^{68}$ This data will be useful in developing more-accurate estimates of RMI's wind resource. Two 34-m meteorological towers are currently installed that record wind speed and direction, temperature, pressure, as well as solar intensity. One wind monitoring tower is on the Jaluit Atoll on the Jaluit High School campus and the second is on Wotje Atoll at the Northern Islands High School. The systems were installed in June and September of 2012, respectively.

The wind turbine capacity factors used in the analysis here were determined by averaging turbine performance model outputs using both the Kwajalein data and the global virtual data.

A summary of the impact of wind energy on BAU diesel generation is shown in Table 11.

Table 11. Wind power total systems size and predicted impact by 2032

\begin{tabular}{|l|l|}
\hline Total Installed Capacity & $1.4 \mathrm{MW}$ \\
\hline Annual Energy Production & $2,360 \mathrm{MWh}$ \\
\hline Displaced Diesel & 3,975 barrels/year \\
\hline Fuel Reduction from BAU & $3.1 \%$ \\
\hline Electricity Contribution in Year 2032 & $3.6 \%$ \\
\hline
\end{tabular}

Source: Utility personnel at Marshalls Energy Company and Kwajalein Atoll Joint Utilities Resources

When properly installed, wind turbines reach above buildings, trees, and other structures that could create turbulence. For this reason, wind turbine installations are often visible and can generate opposition from persons concerned about noise and impacts of their view. A robust permitting process would consider these and other important factors, including environmental review, to identify appropriate sites. Additionally, the installation of wind turbines in areas where extreme weather events are common requires selection of suitable turbines and an assessment of the risk for the turbine structure, which may lead to the need for insurance. At least two manufacturers have a typhoon-rated

\footnotetext{
67 “ERA-Interim.” European Centre for Medium-Range Weather Forecasts, undated. www.ecmwf.int/research/era/do/get/erainterim.

68 “Detail of GEP Project \#2568.” Global Environment Facility, 2013. www.thegef.org/gef/project_detail?projID=2568.
} 
wind turbine. Another manufacturer has two turbine models that are designed to be lowered with approaching storms. Its $220-\mathrm{kW}$ turbine tower is hinged at the base to allow it to be lowered during potential typhoons and extremely high wind events. The rotor on its 1-MW turbine can be lowered from the tower and stowed on the ground using a hoist in the top of the tower.

\subsubsection{Waste-to-Energy}

WTE is a commercially sound, widely deployed option that is considered to be a form of renewable energy by most countries and organizations around the world.

In the wedge analysis, WTE is the largest renewable energy wedge with about $13 \%$ of RMI's 2032 total annual energy requirements produced from a hypothetical 1.2-MW plant. The model assumes that combustible waste on Majuro is used in a steam-powered generator operating at an annual average capacity factor of $79 \%$. The figures are based on an analysis report published in 2010 and funded by the ADB. ${ }^{69}$ The report authors visited Majuro to engage local stakeholders and gather data. The analysis report is a pre-feasibility study that includes sound estimates of total waste available, energy content, and power plant production. It also discusses local factors, including permitting, the challenges of finding operating expertise, raising capital, and the ownership options that are most likely to lead to project development and operational success. Financial feasibility is also addressed.

The 2010 report includes waste quantities generated on Majuro. It does not estimate volumes or the costs and benefits of collecting waste-for-energy from other RMI population centers. The report suggests the WTE is technically feasible and has the added benefits of reducing waste accumulation volumes by $90 \%$, diversification of electricity generation, and providing baseload generation (an important generation characteristic under high renewable energy scenarios necessary to counterbalance variable resources of wind and solar). However, the report concludes that the project is not financially competitive against continued diesel-fired generation. Additionally, the report authors cite high capital costs as a challenge and indicate that development of a plant of this size would likely be one of the larger civil works projects undertaken by RMI.

A wider systems view of WTE in the context of waste disposal, energy needs, and impact on the local economy in terms of not just energy costs but the net benefit of local expenditures versus export of money, creation of local jobs, and improvement of the local environment may improve its attractiveness. Further, a useful application of the waste heat from the power plant would improve project economics. For example, if the waste heat from the WTE facility could be sold to Tobolar for use in copra processing, the project would benefit from an additional revenue stream while the copra industry could benefit from lower utility operating costs. These types of potential synergies should be evaluated in more detail.

A summary of the impact of WTE on BAU diesel generation is shown in Table 12.

\footnotetext{
${ }^{69}$ Pre-Feasibility Study, Waste-to-Energy Facility, Majuro Atoll, Republic of the Marshall Islands. SCS Engineers, May 2010.
} 
Table 12. Waste-to-energy system size and predicted impact by 2032

\begin{tabular}{|l|l|}
\hline Plant Size & $1.2 \mathrm{MW}$ \\
\hline Annual Energy Production & $8,300 \mathrm{MWh}$ \\
\hline Displaced Diesel & 13,980 barrels/year \\
\hline Fuel Reduction from BAU & $10.7 \%$ \\
\hline Electricity Contribution in Year 2032 & $12.8 \%$ \\
\hline
\end{tabular}

Source: Utility personnel at Marshalls Energy Company and Kwajalein Atoll Joint Utilities Resources

\subsubsection{Biomass from Copra}

In addition to sun, wind, and the oceans, coconuts are a significant indigenous resource that has an important place in the RMI's economy and history. Coconuts are collected throughout the Marshall Islands and processed on Majuro at the Tobolar Copra Processing Plant, a state-owned enterprise. CNO is a high-value commodity that is sold to international markets. The remaining copra cake has value as animal feed but accounts for $10 \%$ or less of operating revenue. ${ }^{70} \mathrm{CNO}$ has been considered as an alternative fuel source that could reduce the amount of diesel imported by the RMI. UNDP funded a study ${ }^{71}$ for generation and use of CNO on outer islands for electrification, and the RMI's NEP places a priority on developing "the infrastructure and capacity" for using CNO for fossil fuel substitution in the broader power sector. MEC is currently testing $\mathrm{CNO}$ blended with diesel fuel in an existing diesel genset that has been retrofitted for this purpose. The goal of the test is to determine the impact of this fuel combination on generation efficiency and engine components. However, there are no long-term plans at MEC to use $\mathrm{CNO}$ regularly because $\mathrm{CNO}$ costs more than imported diesel.

Results of a study by Michigan State University commissioned by the College of the Marshall Islands indicates that ethanol can be produced from copra after it is pressed for oil at a rate of approximately 64 gallons per ton of waste copra. If the process were commercialized at this yield rate, the total ethanol production potential is estimated at 140,000 gallons/year or 10\% of RMI's current usage of 1.3 million gallons $^{72}$ of imported gasoline. Ethanol is not used in the wedge analysis of the power sector since its properties do not allow for easy blending with diesel.

The analysis assumes $\mathrm{CNO}$ is blended with diesel for use in existing diesel generators. The plant size in Table 13 represents the approximate capacity of existing generation that would be fueled by renewable coconut-derived biofuels.

A summary of the impact of oil from coconuts on BAU diesel generation is shown in Table 13.

\footnotetext{
${ }^{70}$ Tobolar Processing Plant, Inc. Financial Statements and Independent Auditors' Report, Years Ended September 30,2011 and 2010 (As Restated). Deloitte \& Touch LLP, March 2012.

www.rmioag.com/files/RMI/Component\%20Units/Tobolar_FY2011/Financial\%20Statement\%20(FINAL\%2003192012).pdf

${ }^{71}$ Biofuel electrification on remote atolls in the Marshall Is $\bar{l}$ ands. Republic of the Marshall Islands, Marshalls Energy

Company, United Nations Development Program, Secretariat of the Pacific Applied Geoscience Commission, undated. http://ict.sopac.org/compendium-

documents/CLR 201000026_Pre\%20Feasibility\%20Study\%20Biofuel\%20Electrification\%20Ebon\%20Atoll\%20R\%26.pdf.

${ }^{72}$ National Energy Profile: Republic of the Marshall Islands, Pacific. United Nations Development Programme, 2012.
} 
Table 13. Coconut oil as a fuel source and predicted impact by 2032

\begin{tabular}{|l|l|}
\hline Plant Size & $0.75 \mathrm{MW}$ \\
\hline Annual Energy Production & $5,296 \mathrm{MWh}$ \\
\hline Displaced Diesel & 8,874 barrels/year \\
\hline Fuel Reduction from BAU & $6.8 \%$ \\
\hline Generation Contribution in Year 2032 & $8.2 \%$ \\
\hline
\end{tabular}

Source: Utility personnel at Marshalls Energy Company and Kwajalein Atoll Joint Utilities Resources

Process and plant efficiency improvements would improve the economics of coconut-derived biofuels, and perhaps allow the plant to increase production and operate a greater number of hours per year. This would have important side benefits to some of the outer atolls as residents may be able to increase the amount of copra that they are able to collect and sell. A detailed energy audit of Tobolar would identify priority efficiency updates that could be made.

At the time of the assessment trip, CNO was approximately twice the cost of diesel fuel so although technically possible, integrating $\mathrm{CNO}$ as a fuel supplement for power production would increase power plant operating costs, at least in the near term. However, the benefits of local jobs and reduced dependence on imported oil could offset this difference. An analysis that considers total economic impact and RMI policy is recommended.

\subsubsection{Solar Water Heating}

SWH systems are easy to install and cost-effective, particularly in areas like the RMI with high utility costs and a strong solar resource. New low-cost plastic-bodied units have further improved economics and may be a good fit to the RMI's mild climate and low temperature increase requirements (high coldwater inlet temperature).

The application of SWH and impact on total island energy used is minor because of low hot water usage. However, in niche applications in the RMI, such as hospitals, hotels, and in commercial and industrial kitchens, SWH is cost-effective and an opportunity for these facilities to reduce utility costs.

Typical SWH systems will provide $40 \%$ to $70 \%$ of a water heating load; well-designed systems in the RMI would perform at the higher end of this range. Water heated by solar energy is stored in tanks. The temperature of the stored water is raised, as needed, with supplemental heaters that use electricity or fuel.

This analysis assumes SWH offsets electricity, and that hot water usage in the RMI is modest and concentrated in hotels and hospitals. A summary of the impact of SWH on BAU diesel generation is shown in Table 14. This analysis assumes the typical home and commercial building does not consume hot water. The estimate here considers modest hot water loads at hotels and the Majuro Public Hospital are supplemented by solar heating. 
Table 14. Solar water heating total installation size and predicted impact by 2032

\begin{tabular}{|l|l|}
\hline Total Installed Collector Area & $2300 \mathrm{ft}^{2}$ \\
\hline Annual Energy Savings & $197 \mathrm{MWh}$ \\
\hline Displaced Diesel & 332 barrels/year \\
\hline Fuel Reduction from BAU & $0.3 \%$ \\
\hline Electricity Offset by 2032 & $0.3 \%$ \\
\hline
\end{tabular}

Source: Utility personnel at Marshalls Energy Company and Kwajalein Atoll Joint Utilities Resources

\subsubsection{Ocean Energy}

The potential energy available in the oceans is immense and holds significant promise for renewable power production and for energy efficiency gains by using large district cooling systems. Ocean power production technologies are divided into four categories: tidal, wave, marine current, and OTEC.

If they were commercially viable, ocean power production systems would be a good fit for the RMI because of the proximity of the resource; however, only impounded tidal power systems similar to conventional hydroelectric dams are commercially available today. In this type of system, large dams open and close with tidal cycles to capture water in an estuary or impound structure to create sea elevation differences used to drive hydroelectric turbines. These impound or barrage systems are not feasible in the RMI because of the small changes in tidal elevation and limited land area.

OTEC is a method of converting the vertical temperature difference between the surface and deep ocean water to electricity. Typically an average temperature gradient of $36^{\circ} \mathrm{F}\left(20^{\circ} \mathrm{C}\right)$ is required for this type of energy conversion to be considered economically feasible. Surface water is generally about $77^{\circ} \mathrm{F}-84^{\circ} \mathrm{F}$ in a tropical area. Ocean water at a depth of 3,200 feet is consistently about $41^{\circ} \mathrm{F}$, giving the desired temperature gradient of at least $36^{\circ} \mathrm{F}$. Global temperature gradient maps indicate the highest global gradients exist along the equator in the western Pacific, suggesting RMI has access to a strong OTEC resource. $^{73}$ This significant thermal gradient is a good reason to consider OTEC; however, no commercially successful project has ever been completed. The largest successful OTEC demonstration project was built in Hawaii in 1992 and achieved 103-kW peak power production. ${ }^{74}$ The project showed successful demonstration of the technology but had multiple operational challenges. Furthermore, the environmental impacts would need to be studied carefully due to the large flows of deep cold and warm surface water mixing. In addition, OTEC has associated land requirements that should be considered. For this reason, OTEC is not considered further in the current analysis.

\footnotetext{
73 “Marine \& Hydrokinetics Atlas.” National Renewable Energy Laboratory, 2013. Accessed March, 2013: http://maps.nrel.gov/mhk atlas.

${ }^{74}$ Edenhofer, O.; Pichs-Madruga, R.; Sokona, Y.; Seyboth, K.; Matschoss, P.; Kadner, S.; Zwickel, T.; Eickemeier, P.; Hansen, G.; Schlömer, S.; von Stechow, C. IPCC Special Report on Renewable Energy Sources and Climate Change Mitigation. Cambridge, UK, and New York: Cambridge University Press, 2011.
} 


\section{Renewable Energy System Costs}

Previous sections of this report have examined the technical potential for renewable energy systems in the RMI, based primarily on resource availability. A thorough evaluation of the potential for renewable energy project development in the RMI needs to take into account the likely system costs as well. There have not been enough such projects in the RMI to provide country-specific costs but this section provides typical system costs that can be used as the basis for comparing one renewable energy technology with another.

According to the International Renewable Energy Agency (IRENA), ${ }^{75}$ renewable technologies account for approximately half of all new power generation capacity additions worldwide, and renewable technologies are now the least expensive solution for new capacity in an increasing number of countries and regions, especially where oil-fired generation is the dominant source of power.

The costs of renewable power systems are very site specific, partly because renewable resources are distributed unevenly across regions and even within a country, and partly because the costs of delivering and installing the systems varies greatly with both the distance from major shipping centers and the type of terrain where the systems are to be installed. This is especially true for remote islands nations, such as the RMI. It is therefore very important to collect local resource data and issue well-written, technically sound requests for proposals (RFPs) for specific technologies to develop accurate estimates of the local potential for renewable power generation and the associated costs of installation and operation. The cost estimates in this section do not include the cost of shipping materials and installation personnel to the RMI.

\subsection{Treatment of Biomass and Waste-to-Energy Technologies}

With the exception of landfill-gas-to-energy (LFGTE) systems, which are only used with landfilled municipal solid waste (MSW), WTE technologies are considered to be a subset of biomass-to-energy conversion technologies. Biomass energy conversion technologies are described in Table $15 .^{76}$ Of those technologies, combustion and anaerobic digestion (AD) technologies are considered to be commercial. Pyrolysis and gasification technologies are not commercial.

\footnotetext{
${ }^{75}$ Renewable Power Generation Costs in 2012: An Overview. International Renewable Energy Agency, 2012. Accessed July 2013: http://irena.org/menu/index.aspx?mnu=Subcat\&PriMenuID=36\&CatID=141\&SubcatID=277.

${ }^{76}$ Funk, K. et al., Waste Not, Want Not: Analyzing the Economic and Environmental Viability of Waste-to-Energy (WTE) Technology for Site-Specific Optimization of Renewable Energy Options. TP-6A50-52829. Golden, CO: National Renewable Energy Laboratory, February 2013.
} 
Table 15. Biomass conversion technologies

\begin{tabular}{|c|c|c|c|}
\hline Summary Technology & Description & Mode of Operation & $\begin{array}{l}\text { Commercially } \\
\text { Available for WTE }\end{array}$ \\
\hline Combustion & $\begin{array}{l}\text { Thermal conversion of a } \\
\text { feedstock utilizing } \\
\text { excess air or oxygen as } \\
\text { oxidant to generate heat. }\end{array}$ & $\begin{array}{ll}\text { - } & \text { Grate } \\
\text { - } & \text { Bubbling fluidized } \\
\text { bed } \\
\text { - } \\
\begin{array}{l}\text { Circulating fluidized } \\
\text { bed }\end{array} \\
\end{array}$ & $\begin{array}{l}87 \text { installations in the } \\
\text { United States }\end{array}$ \\
\hline Pyrolysis & $\begin{array}{l}\text { Thermal conversion of a } \\
\text { feedstock in the absence } \\
\text { of air or oxygen as } \\
\text { oxidant to generate a } \\
\text { synthesis gas or fuel and } \\
\text { pyrolysis oil (plasma arc } \\
\text { capabilities of operating } \\
\text { in excess of } 20,000^{\circ} \mathrm{F} \text { ). }\end{array}$ & $\begin{array}{ll}\text { - } & \text { Horizontal } \\
\text { - } & \text { Vertical } \\
& \text { (updraft/downdraft) } \\
& \text { Plasma arc }\end{array}$ & $\begin{array}{l}\text { Two installations in } \\
\text { the United States }\end{array}$ \\
\hline Gasification & $\begin{array}{l}\text { Thermal conversion of } \\
\text { feedstock in a limited } \\
\text { atmosphere of air or } \\
\text { oxygen as oxidant to } \\
\text { generate a synthesis } \\
\text { gas or fuel. }\end{array}$ & $\begin{array}{l}\text { Horizontal stationary } \\
\text { Horizontal rotating } \\
\text { Vertical } \\
\text { (updraft/downdraft) } \\
\text { Stationary grate } \\
\text { Bubbling fluidized } \\
\text { bed }\end{array}$ & $\begin{array}{l}\text { No installations in the } \\
\text { United States }\end{array}$ \\
\hline Anaerobic Digestion & $\begin{array}{l}\text { Biochemical conversion } \\
\text { of a feedstock in the } \\
\text { absence of oxygen to } \\
\text { generate biogas. }\end{array}$ & $\begin{array}{ll}- & \text { Mesophilic }\left(77^{\circ} \mathrm{F}-\right. \\
& \text { 100F) } \\
\text { - } & \text { Thermophilic } \\
& \left(122^{\circ} \mathrm{F}-135^{\circ} \mathrm{F}\right)\end{array}$ & $\begin{array}{l}\text { Multiple installations } \\
\text { in the United States } \\
\text { (total quantity } \\
\text { unknown) }\end{array}$ \\
\hline
\end{tabular}

Most MSW is incinerated (combusted). System costs for biomass and WTE combustion are comparable, although WTE "delivered energy" costs may be higher than indicated in Table 16 depending on the extent to which noncombustible materials must be separated from the waste stream. Waste stream separation costs are highly site-specific and are not included in Table 16.

\subsection{Typical Renewable Energy System Costs}

Table 16 provides the best available data on typical renewable energy systems costs. Only commercially available and mature technologies are included in the table.

LFGTE and AD technologies are not included in the table as the NREL assessment team was not able to gather sufficient data to ascertain whether there is any technical potential for implementing these technologies in the RMI. The biomass combustion system costs listed under the "global" columns below are based on system size of $25 \mathrm{MW}$, which is much larger than could be built in the RMI. The costs provided under the column labeled "islands" are based on unpublished, in-house estimates developed by NREL for WTE projects that other islands are investigating. It should be noted that very few small-scale WTE systems similar to what would be suitable for the RMI have been built anywhere in the world.

Large ground-mounted solar PV systems and larger land-based wind power systems are not likely to be implemented in the RMI due to issues with land availability, but system costs for these technologies are included due to the high resource potential in the RMI. PV system costs assume that the system is gridconnected (i.e., they do not include the cost of an energy storage system). Possible installation on land infill sites (commonly known as reclaimed land or previously disturbed land), reefs, or in shallow lagoon waters may expand location opportunities. See Figure 15 to get an idea of how the addition of energy storage (typically lead acid batteries) can raise the cost of energy from (off-grid) PV systems in Pacific islands. Note that, while off-shore wind systems are commercially available and popular in Europe, there are currently no commercial facilities operating in North America. 
Table 16. Estimated cost of energy and installation costs for renewable energy systems

\begin{tabular}{|c|c|c|c|c|c|c|c|}
\hline \multirow{2}{*}{ Technology } & \multirow{2}{*}{$\begin{array}{l}\text { Resource } \\
\text { Potential }\end{array}$} & \multirow{2}{*}{$\begin{array}{l}\text { Representative } \\
\text { Technology } \\
\text { Characteristics }\end{array}$} & \multicolumn{2}{|c|}{$\begin{array}{l}\text { Approximate Cost } \\
\text { of Delivered Energy } \\
\text { (\$/kWh) }\end{array}$} & \multicolumn{2}{|c|}{$\begin{array}{c}\text { Estimated Capital } \\
\text { Cost of Installation } \\
(\$ / \mathrm{kW})\end{array}$} & \multirow{2}{*}{$\begin{array}{l}\text { Land } \\
\text { Use } \\
\text { Impact }\end{array}$} \\
\hline & & & Global & $\begin{array}{l}\text { Islands } \\
\text { (sample) }\end{array}$ & Global & $\begin{array}{l}\text { Islands } \\
\text { (sample) }\end{array}$ & \\
\hline $\begin{array}{l}\text { Biomass } \\
\text { and WTE } \\
\text { Incineration }\end{array}$ & Medium & $\begin{array}{l}\text { Plant size: } 25-100 \mathrm{MW} \\
\text { Capacity factor: } 70 \%- \\
80 \%\end{array}$ & $\begin{array}{l}\$ 0.08- \\
\$ 0.18\end{array}$ & $\begin{array}{l}\$ 0.13- \\
\$ 0.28\end{array}$ & $\begin{array}{l}\$ 3,000- \\
\$ 4,700\end{array}$ & $\$ 8,500$ & Low \\
\hline $\begin{array}{l}\text { Solar PV } \\
\text { (rooftop, } \\
\text { small-scale } \\
\text { systems) }\end{array}$ & High & $\begin{array}{l}\text { Peak capacity: } \\
3 \text { kW-5 kW (residential) } \\
100 \text { kW (commercial) } \\
500 \text { kW (industrial) }\end{array}$ & $\begin{array}{l}\$ 0.22- \\
\$ 0.44\end{array}$ & $\begin{array}{l}\text { Not } \\
\text { available }\end{array}$ & $\begin{array}{l}\$ 2,500- \\
\$ 3,300\end{array}$ & $\begin{array}{l}\$ 5,000- \\
\$ 8,000\end{array}$ & Negligible \\
\hline $\begin{array}{l}\text { Solar PV } \\
\text { (ground- } \\
\text { mounted, } \\
\text { utility-scale) }\end{array}$ & High & $\begin{array}{l}\text { Peak capacity: } \\
2.5 \mathrm{MW}-100 \mathrm{MW}\end{array}$ & $\begin{array}{l}\$ 0.20- \\
\$ 0.37\end{array}$ & $\begin{array}{l}\$ 0.19- \\
\$ 0.36\end{array}$ & $\begin{array}{l}\$ 1,800- \\
\$ 2,400\end{array}$ & $\begin{array}{l}\$ 4,000- \\
\$ 6,000\end{array}$ & $\begin{array}{l}\text { 2-8 acres } \\
\text { per MW }\end{array}$ \\
\hline $\begin{array}{l}\text { Land-Based } \\
\text { Wind } \\
\text { (small- } \\
\text { scale) }\end{array}$ & High & $\begin{array}{l}\text { Turbine size: } \\
\text { up to } 100 \mathrm{~kW}\end{array}$ & $\begin{array}{l}\$ 0.15- \\
\$ 0.20\end{array}$ & $\begin{array}{l}\$ 0.10- \\
\$ 0.20\end{array}$ & $\begin{array}{l}\$ 3,000- \\
\$ 6,000\end{array}$ & $\$ 4,000$ & Low \\
\hline $\begin{array}{l}\text { Land-Based } \\
\text { Wind } \\
\text { (utility-scale) }\end{array}$ & High & $\begin{array}{l}\text { Turbine size: } \\
\text { 1.5 MW-3.5 MW } \\
\text { Capacity factor: } 20 \%- \\
40 \%\end{array}$ & $\begin{array}{l}\$ 0.05- \\
\$ 0.17\end{array}$ & $\begin{array}{l}\$ 0.10- \\
\$ 0.20\end{array}$ & $\begin{array}{l}\$ 1,400- \\
\$ 2,500\end{array}$ & $\$ 3,600$ & High \\
\hline $\begin{array}{l}\text { Offshore } \\
\text { Wind }\end{array}$ & High & $\begin{array}{l}\text { Turbine size: } \\
1.5 \mathrm{MW}-7.5 \mathrm{MW} \\
\text { Capacity factor: } 35 \%- \\
45 \%\end{array}$ & $\begin{array}{l}\$ 0.11- \\
\$ 0.22\end{array}$ & $\begin{array}{l}\$ 0.20- \\
\$ 0.30\end{array}$ & $\begin{array}{l}\$ 3,800- \\
\$ 5,900\end{array}$ & $\$ 4,300$ & Low \\
\hline $\begin{array}{l}\text { Solar Hot } \\
\text { Water }^{\mathrm{a}} \\
\text { (rooftop) }\end{array}$ & High & $\begin{array}{l}\text { Collector type: } \\
\text { flat-plate, evacuated tube }\end{array}$ & $\begin{array}{l}\text { Not } \\
\text { available }\end{array}$ & $\begin{array}{l}\$ 0.15- \\
\$ 0.20\end{array}$ & $\begin{array}{l}\$ 1,000- \\
\$ 1,700\end{array}$ & $\begin{array}{l}\$ 4,000 \\
\text { per } \\
\text { system }\end{array}$ & Negligible \\
\hline
\end{tabular}

${ }^{\mathrm{a}}$ Global capital cost for solar hot water is for systems ranging in size from $2.1 \mathrm{~kW}_{\mathrm{th}}-35 \mathrm{~kW}_{\mathrm{th}}$. Island capital cost is the cost of a system sufficient to meet the needs of a four-person household. Island energy cost is based on the system costs and electrical energy consumption offset by the use of the solar thermal system.

Global cost ranges are from the Renewable Energy Policy Network for the 21 st Century. ${ }^{77}$ Island costs are from NREL ${ }^{78}$ and are based on the Caribbean islands, where more data is available. Costs in the RMI are likely to be higher.

\subsection{Cost of Electricity from Renewable Power Systems on Pacific Islands}

Very little aggregated data on energy system costs is available for Pacific islands. A 2012 IRENA report $^{79}$ includes the following chart (Figure 15). IRENA does not provide information on how many islands were included in their survey, or typical system sizes and characteristics, but this chart is included as the best source of recent information on Pacific island system costs.

\footnotetext{
${ }^{77}$ Renewables 2012 Global Status Report. Renewables Energy Policy Network for the $21^{\text {st }}$ Century, 2012.

${ }^{78}$ Lantz, E. et al., U.S. Virgin Islands Energy Road Map: Analysis. NREL/TP-7A20-52360. Golden, CO: National Renewable Energy Laboratory, September 2011.

${ }^{79}$ Renewable Power Generation Costs in 2012: An Overview. International Renewable Energy Agency, 2012. Accessed July 2013: http://irena.org/menu/index.aspx?mnu=Subcat\&PriMenuID=36\&CatID=141\&SubcatID=277.
} 


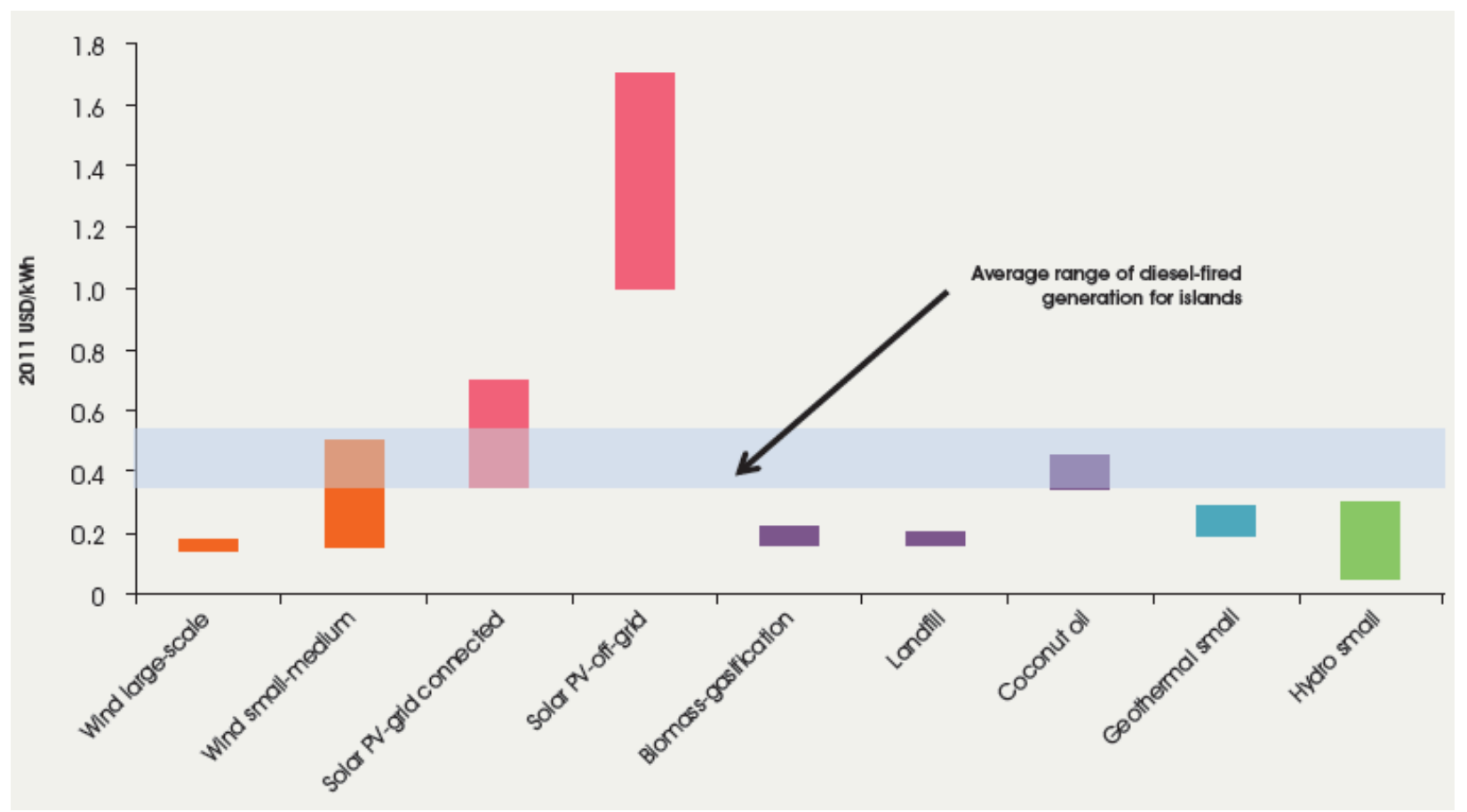

Figure 15. Levelized cost of electricity from renewable power systems on Pacific islands

According to IRENA, "the barriers faced by islands to the deployment of renewable technologies are often more challenging than in other locations. With some exceptions, islands typically represent small, dispersed markets that cannot benefit from economies of scale and highly competitive supplier markets. Islands also have higher transport costs (sometimes much higher in the case of outer islands) and higher margins for the costs of procuring the balance of system components. The need to move qualified personnel between islands means installation costs will also be higher. Transaction costs and project development costs will also be higher due to small-scale island markets and their geographically dispersed nature." 


\section{Project Development Challenges in the RMI}

The goals described in the RMI's NEP did not result in actual implementation of many of the projects recommended in the plan. One possible explanation is that, although energy prices remain high, they are much more stable than they were in 2008, and the sense of urgency has diminished. Yet recent efforts have been made to create additional momentum toward project implementation. For these efforts to succeed, the barriers to development must be identified and addressed. This section highlights some of the key barriers, and Section 9 describes some general policy and project development approaches that could help overcome these barriers. Section 10 summarizes the recommendations for overcoming the specific barriers identified below.

\subsection{Overview of Challenges}

Many remote island communities face a common set of challenges in implementing energy projects. Those challenges are listed below along with some obstacles that are particularly problematic in the RMI. Some of the challenges are described in greater detail in other sections (noted in the bullet points below).

- Competing priorities - In most island countries, energy is just one among many important development objectives. Priorities can change rapidly, which can lead to delays in energy project development. This results in higher-than-anticipated project costs, representing an inefficient use of local and donor resources, and development targets not being met (see Section 8.2).

- Absence of an optimized project planning framework and standardized project development protocols-Each international donor has its own approach to project development and, as a result of varying donor experience with project implementation in remote communities, not all of these approaches address key project development fundamentals that are common to all energy projects. This problem is exacerbated by the absence of strong local policies designed to promote energy project development and guide the actions of well-intentioned donors

- Lack of detailed local information required to make informed decisions about which energy projects to pursue - This report itself is a reflection of the fact that it can be very difficult to gather basic information about local energy supply and demand (Section 4) and the likely cost of new projects (Section 7). Without this information, it is difficult to know which projects are the most cost-effective and appropriate to the local situation.

- In some cases, the lack of data results from the fact that local utilities may not have had an incentive to keep detailed records, something that can be addressed through a change in business practices and by applying some resources to long-term planning.

- When very few comparable projects have been undertaken locally or nearby, one of the most reliable ways to ascertain likely project costs is to issue tightly specified RFPs for specific technologies. However, a lack of data regarding local energy markets, laws and regulations governing energy project implementation, potential site access issues, and available energy resources will reduce the reliability and number of RFP responses, as respondents typically add large contingencies to their estimates for any missing information that could increase their own project development costs and risks.

- Donor challenges - In addition to neglecting key project fundamentals during the planning phase, international donors sometimes fail to address other aspects that are critical to project success. Some of these issues are exacerbated by similar problems within the RMI (see Section 8.3). 
- Lack of coordination-The multitude of donors often have their own agendas and develop projects in a piecemeal fashion instead of leveraging each other's efforts by coordinating their activities.

- Inadequate project oversight-Many donors are not intimately familiar with the local situation and some end up using the wrong vendor or contractor to supply and install equipment, hiring inexperienced local staff, not making sure their project funds are spent in ways that further the overall project goals, and not following standard project close-out procedures that are designed to capture "lessons learned" that can be used to develop a set of best practices that can be applied to future projects.

- Failing to address post-construction operations and maintenance needs-Many international donors are overly focused on project completion and do not pay sufficient attention to ensuring that the funds and a skilled workforce are in place to operate and maintain project equipment for the life of the project.

- RMI institutional challenges - The lack of independent utility oversight, some missing technical skills amongst the workforce, and the absence of energy policies and regulations in the RMI present significant challenges to project development.

- RMI utility financial challenges - The practice of providing free electricity to some landowners makes it difficult for the local utilities to balance their books.

- External risk factors - Some project challenges result from a lack of foresight on the part of the international donors or the local government, but others are more difficult to predict. Contingency planning can help to mitigate the impact of some of these risk factors.

- A downturn in the local economy or a change in global markets can quickly shift local development priorities or the financial viability of a particular energy project. A rapid and sustained increase in global oil prices, for example, could immediately improve the economics of renewable energy projects as a whole, and the potential value of coconut oil, as an example, a diesel substitute in particular.

- Natural disasters can switch local and donor priorities overnight from energy project development to infrastructure reconstruction, delaying the implementation of projects that are already under way. The remoteness of many island communities and their limited local resources can further exacerbate the effects of natural disasters by increasing both the cost and time required for reconstruction.

- Lack of stakeholder engagement - Education and outreach to local stakeholders, including landowners, ordinary citizens, municipal leaders, and other influential members of the community, is an often-overlooked aspect of successful project development. It is important that stakeholders are not just informed about, but are fully engaged and personally invested in, the projects.

\subsection{Competing Priorities}

The energy sector in the RMI is just one part of a complex economic, social, and political system. It is influenced by the local and international economy, global oil markets, available workforce skills, local policy, and RMI government and utility actions. The RMI government, international donors, and the U.S. government are working to address needs in every area of the RMI, including:

- Infrastructure

- Health

- Education 
- Energy

- Environmental issues

- Preparation for climate change

- Work force development

- Governance

- Institutional capacity-building.

The energy sector is just one challenge among many. Small economies of scale are counterbalanced, at least in part, by high energy costs, opportunities for integrated solutions, assistance provided through the Compact, and an actively engaged international donor community. The U.S. government has an important part to play in developing transformative policies and projects through the joint (RMI and DOI) approval process for projects funded by the Compact and through support provided by other U.S. federal grants and guaranteed loans. But the international community does not always know the best way to navigate around the specific obstacles to project development in the RMI. Strong leadership by the RMI government is necessary to overcome local barriers and to ensure that donor resources are applied in ways that are most likely to result in development successes.

\subsection{Donor Challenges}

One of the biggest challenges in the RMI is the lack of communication and coordination among international donors. Failure to track projects and their progress makes it difficult for future donors to build on and contribute to earlier successes. In addition, if the in-flow of funding for a project is not continuous, it can be difficult to restart a project once funding does arrive. The donors must first reestablish where the project left off, or where other projects have contributed if they hope to make worthwhile contributions. This leads to inefficiencies in spending. If they do not determine what work has already been done, donors risk duplicating efforts, or omitting crucial steps that would lead to effective changes in the RMI.

The existing lack of communication and coordination between the United States, other international donors, and the RMI government can be partially attributed to the limited institutional mechanisms in place to support widespread dissemination of renewable and energy efficient technologies, and the diffusion of knowledge and skills required for the operation and maintenance of energy systems. Portions of grant money should be spent strengthening local capacity rather than simply providing systems that cannot be properly operated and maintained once the donors leave. This would in turn help increase the success of projects, and increase public support for additional renewable energy and energy efficiency projects.

In addition, there is a lack of appropriate legal, policy, and program management frameworks in the RMI. This framework is necessary for projects to be implemented and operate successfully. Creating these frameworks could also encourage additional investment in renewable energy and energy efficiency projects within the RMI by reducing investor risk.

The number of stakeholders active in the RMI and the lack of strong institutional capacity results in another challenge: inadequate access to baseline data and incomplete performance reports. Data tracking within the RMI utility sector is not easily accessible to external donors. The unique circumstance surrounding the RMI, mainly their dependence on external donors, requires data to be more easily accessible if projects are to be conducted efficiently and successfully. To perform proper analysis of the RMI's power system, current, frequent data is required. This can be even more critical when considering renewable energy, which can be intermittent and requires data that details electricity supply and demand on a sub-hourly basis. Often, any data that is collected is very difficult to gather from the utilities as it is 
often recorded by hand, not archived, and/or staff does not have time to dig into records to gather the data. This slows down project implementation, leading to further inefficiencies in application of donor funding. The lack of data also contributes to higher financial uncertainty and risk that are significant impediments to renewable energy and energy efficiency project investment by the private sector.

\subsection{Other RMI Institutional Challenges}

Technical capacity in the RMI is not always sufficient for the successful planning, implementation, and monitoring of energy-related projects. The lack of technical capacity results in insufficient staff and skills, limiting the RMI's ability to monitor day-to-day energy sector grant operations. ${ }^{80}$

Another institutional challenge in the RMI is that the utility does not have an independent regulating body. The president and president's cabinet act as the utility regulators, with policy guidelines being set by the utility board of directors. Having independent utility regulation is important for protecting the public interest, creating proper safety standards, and determining appropriate electricity rates. The existing rate structure in the RMI does not allow MEC to recover its costs. This results in budget shortfalls and limits the utility's ability to improve services and address other challenges within the energy system.

The RMI has few energy policies, incentives, regulations, and standards. Strengthening the framework for creating policies and regulations would allow the RMI to take advantage of tools that can facilitate market changes and bolster renewable energy development. This would also reduce investor risk, and facilitate investment from international donors and private developers.

\subsection{RMI Utility Financial Challenges}

A major barrier to the success of the RMI energy system as a whole is the existence of the landowner's electricity concession program. The program allows landowners who have distribution poles on their property to receive up to $1,000 \mathrm{kWh}$ free of charge per month. Unfortunately, the system has very little oversight, and there is no method for verifying landowner claims. Originally, there were only 150 landowners granted concessions under the program. This number has since risen to over 600 . The result is that one out of every four domestic consumers receives free electricity, and that number continues to increase. The current program does not encourage energy conservation and costs the utilities approximately $\$ 1.8$ million per year. The landowner's concession program contributes to the financial challenges created by the current tariff structure, which does not cover actual costs. The tariff structure creates a challenge for the utilities by forcing them to operate in the red.

\footnotetext{
${ }^{80}$ Implementation Activities Have Progressed, but the Marshall Islands Faces Challenges to Achieving Long-Term Compact Goals. Testimony before the Committee on Energy and Natural Resources, U.S. Senate. Statement of David B. Gootnick, Director International Affairs and Trade. Sept. 25, 2007. Accessed July 15, 2013: www.gao.gov/assets/120/117473.pdf.
} 


\section{The Need for Energy-Related Policies and a Standardized Project Development Process}

This section describes some general policy and project development approaches that could help overcome the barriers to implementing renewable energy and energy efficiency projects in the RMI.

Policy can be an effective tool for promoting the adoption and subsequent development of clean energy projects (see Figure 16). By incorporating public outreach and participation, the process of developing new policies can also help to inform people and allay any concerns they may have about adopting unfamiliar technologies.

A policy is a principle or rule to guide decisions and achieve a desired outcome. The term does not denote what is actually done; this is typically referred to as either procedure or protocol.

Whereas policies describe the "what" and the "why," procedures and protocols address the "what," the "how," the "where," and the "when." Policies are generally adopted by the board of, or senior governance body within, an organization, whereas procedures or protocols would be developed and adopted by senior management or the implementing entity within an organization.

Policy creates the environment to transition

from the reality of today to the desired future

of tomorrow.

Policy can be leveraged to maximize the

benefits of transitioning to a new energy

future.

The policy process creates the opportunity to

prioritize among a diverse set of problems and

solutions.

Figure 16. Advantages of a strong policy framework

Establishing energy-related policies is a necessary precursor to any significant transformation in the energy sector.

One of the challenges with developing policies and their implementing procedures is that, at some level, inconsistencies, gaps, and overlaps are inevitable - for example, when balancing fiscal responsibility with ecological integrity.

Some of the key principles that could guide the RMI toward a sustainable and financially prudent energy future are listed below.

- Adopt energy strategies that will enhance the general quality of life of RMI residents

- Promote clean energy technologies that help to sustain a healthy environment in the long term 
- Promote sound environmental stewardship and fiscal responsibility through energy conservation and energy efficiency

- Promote technologies that support local economic vitality

- Support options that will mitigate and reduce energy market volatility, stabilize electricity rates, and increase the reliability of electricity delivery.

It is important to have a robust set of policies that are:

- Comprehensive-Barriers to renewable energy and energy efficiency can be diverse; growth may be halted as a result of any number of wholly unrelated barriers

- Broad-based-Applies across all types of entities and sectors

- Multifaceted-Addresses potential problems and barriers from various angles

- Multi-tiered - Includes mandates or quotas but also addresses siting and permitting

- Practical-Focus on small victories

- Long-term - Create the market conditions to build a real and sustainable industry.

No single policy exists in isolation. Policy success is often determined by the ability to address multifaceted barriers with the appropriate mix of tools. One of the key benefits of policy development is that through this process, a specific set of challenges can be identified and strategies developed to address them; it does not necessarily attempt to be everything to everyone all at the same time. This process is incremental and topic-specific. A deliberate and methodical approach can help to minimize policy gaps and failures.

\subsection{Recommendations for Energy-Related Procedures}

The following are some policies, procedures, and specific actions that could potentially attract greater investment in renewable energy and energy efficiency technologies, and facilitate project development in the RMI.

\subsubsection{Develop Multiple Financial Mechanisms and Opportunities}

1. Explore public-private partnerships with local businesses, developers, and banks with the idea of creating local markets for renewable power generation, energy efficiency, and energy conservation products and services.

2. Investigate third-party financing of energy projects.

3. Pursue subsidies for renewable energy projects.

4. Consider policies that could reduce the overall cost of electricity - creating a fair and balanced tiered electricity rate structure (e.g., peak pricing), providing grants to encourage electricity consumers to install renewable power generation systems, and providing subsidies for energyefficient household appliances.

5. Investigate alternative third-party financing models, such as power purchase agreements and performance savings contracting.

\subsubsection{Standardize and Optimize the Project Development Process}

In order to entice investment - whether from public-sector donors or private-sector investors - it is important to reduce the level of project uncertainty as much as possible. 
There are several ways to do this. One of the most important approaches is to carry out the research necessary to provide quality information to potential investors when using the RFP mechanism to obtain real-world project cost estimates.

Giving potential investors accurate, detailed information about potential project parameters will increase their interest in responding to the RFP and also improve the accuracy of their cost estimates. Providing detailed, actionable information in RFPs also casts a wider net, encouraging experienced, high-quality companies to respond. Providing information on a community's legal requirements for building a project —including site access, permitting, and environmental processes, and what types of project ownership structures are recognized locally_can also be highly beneficial to potential investors.

It is a good idea to survey existing legal requirements, eliminating unnecessary steps, and streamlining processes as an incentive to bring in investors. This strategy has multiple benefits - it organizes a community, encouraging people to survey what exists and develop what is needed; it provides consensus; and offers investors high-quality information and reduces their uncertainty.

A description of NREL's recommended models for overall energy planning and specific project development steps follows. The RMI has already been successful in engaging many stakeholders and accomplished several of these steps by developing the NEPEAP.

\subsection{A Model for Energy Planning}

The model depicted in Figure 17 has been developed by NREL as an overall guide to implementing energy policies and projects.

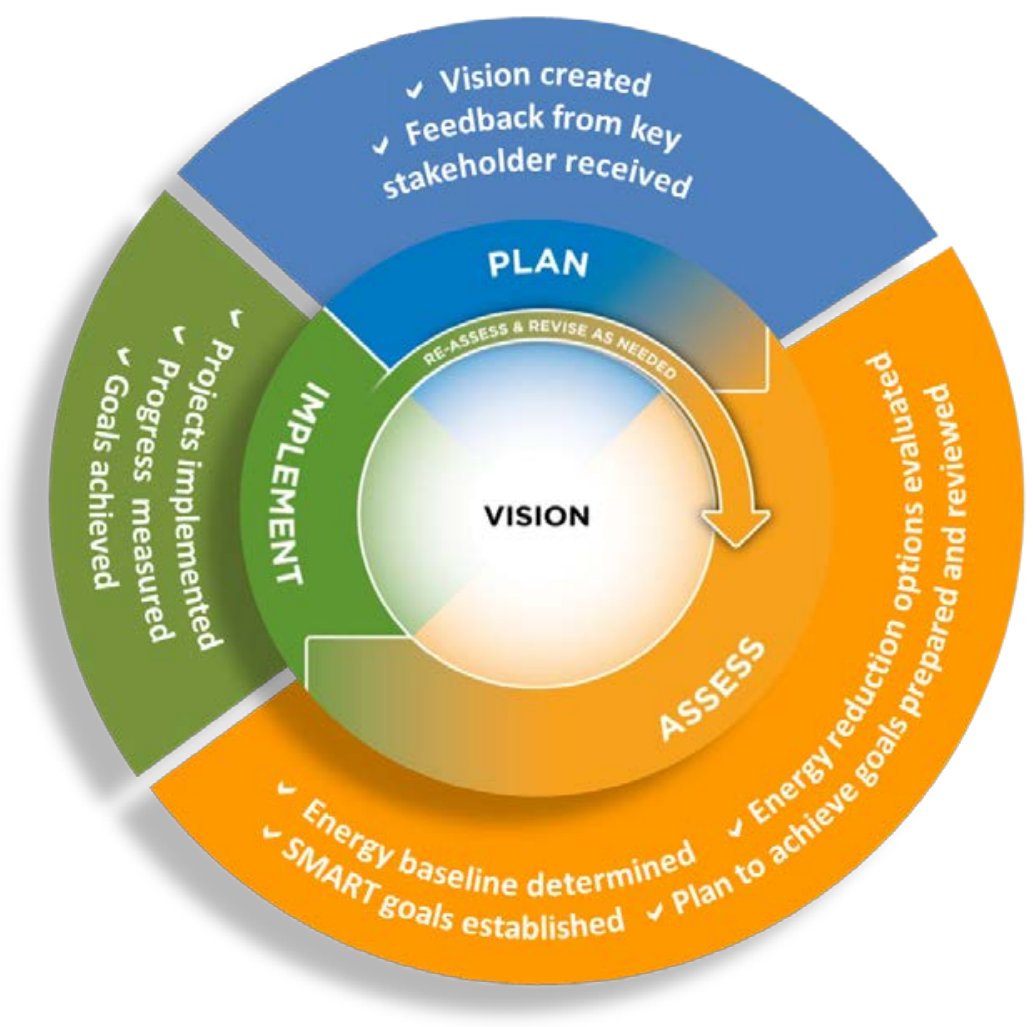

Figure 17. NREL's process for energy transformation 


\subsubsection{Plan}

The planning phase includes these steps:

- Identify and bring together stakeholders

- Develop a vision for the community's energy transformation.

\subsubsection{Assess}

The assessment phase includes these steps:

- Determine an energy baseline

- Evaluate options

- Develop goals

- Prepare an energy plan

- Solicit feedback on the plan from a broad set of stakeholders.

The goals of this phase are to:

- Determine the community's energy baseline

- Establish specific, measureable, attainable, relevant, and time-bound goals for energy transformation

- Put the goals into a plan for action.

\subsubsection{Implement}

The implementation phase includes these steps:

- Develop, finance, and implement projects

- Create early successes

- Evaluate effectiveness and revise as needed.

The goals of this phase are to:

- Implement projects that can build community support for ongoing and future energy projects

- Measure the progress and effectiveness of the plan and its projects.

Figure 18 demonstrates the strategic plan and the steps taken in each phase. 


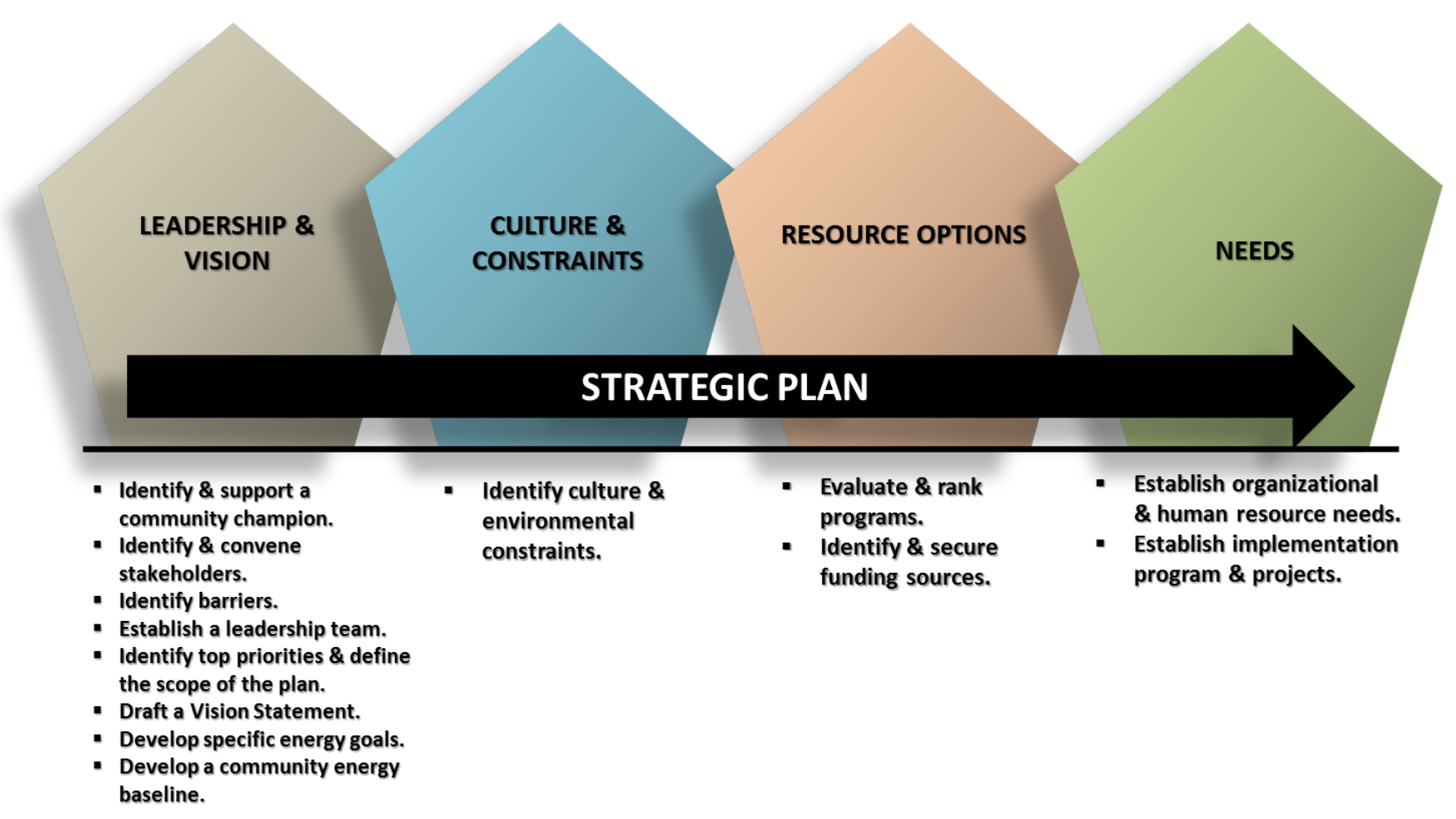

Figure 18. The strategic plan and the steps involved in the process

\subsection{A Standardized Framework for Project Development}

Before beginning a project, it is important to evaluate the risks and investment decisions required for successful renewable energy and energy efficiency project development. The two-phase model described below was developed by NREL based on experience with thousands of energy projects. ${ }^{81}$

\subsubsection{Establish Fundamental Project Parameters Before Commencing Development}

Strong project fundamentals and an understanding of how a project fits within a portfolio of opportunities help to ensure the project evaluation and development team has the commitment and clarity needed to secure the resources required to develop a renewable energy or energy efficiency project and to persevere through the sometimes complicated and lengthy project development process.

Establishing the following project fundamentals (referred to as BEPTC) will help the project evaluation team make an informed decision about whether to move the project forward.

The five important project fundamentals identified by NREL are:

- Baseline - Analyze the current situation for the site, its energy supply, and identify specific objectives

- Economics - Analyze total costs of acquiring energy from existing sources and from proposed sources

- Policy_Examine federal, state, local, and regulatory policy environments for barriers; address barriers prior to expending significant resources

- Technology_Assess available renewable resources and the commercially available conversion technologies

\footnotetext{
81 “Project Development Model.” National Renewable Energy Laboratory, 2012. www.nrel.gov/tech_deployment/project_development_model.html.
} 
- Consensus - Obtain agreement from all stakeholders, the community, officials, and staff, and procure the financial resources to proceed.

\subsubsection{Standard Project Development Steps}

Once the decision has been made to proceed with a project, using a standardized project development model can be beneficial. NREL's model is referred to as SROPTTC. The seven elements that NREL recommends to organize and evaluate the risks and investment decisions required in the project development phase include:

- Site - Identify the physical location for the physical assets of a project, including property rights, site control, length of tenure, terms and conditions, etc.

- Resource - Characterize and understand the renewable resource being considered.

- Off-take - Establish and secure by contract the buyer of both the energy and any other characteristics of output (e.g. renewable energy credits).

- Permits - Identify and obtain all permits necessary for project construction and operation.

- Technology - Invest in engineering design, equipment selection, and procurement activities of the chosen technology.

- Team-Assemble a fully qualified team that addresses all business, technical, financial, legal, and operational aspects.

- Capital-Attract financial resources necessary for final development, construction, commissioning, and initial operations.

Figure 19 represents how risk initiates a distinct profile when mapped over time.

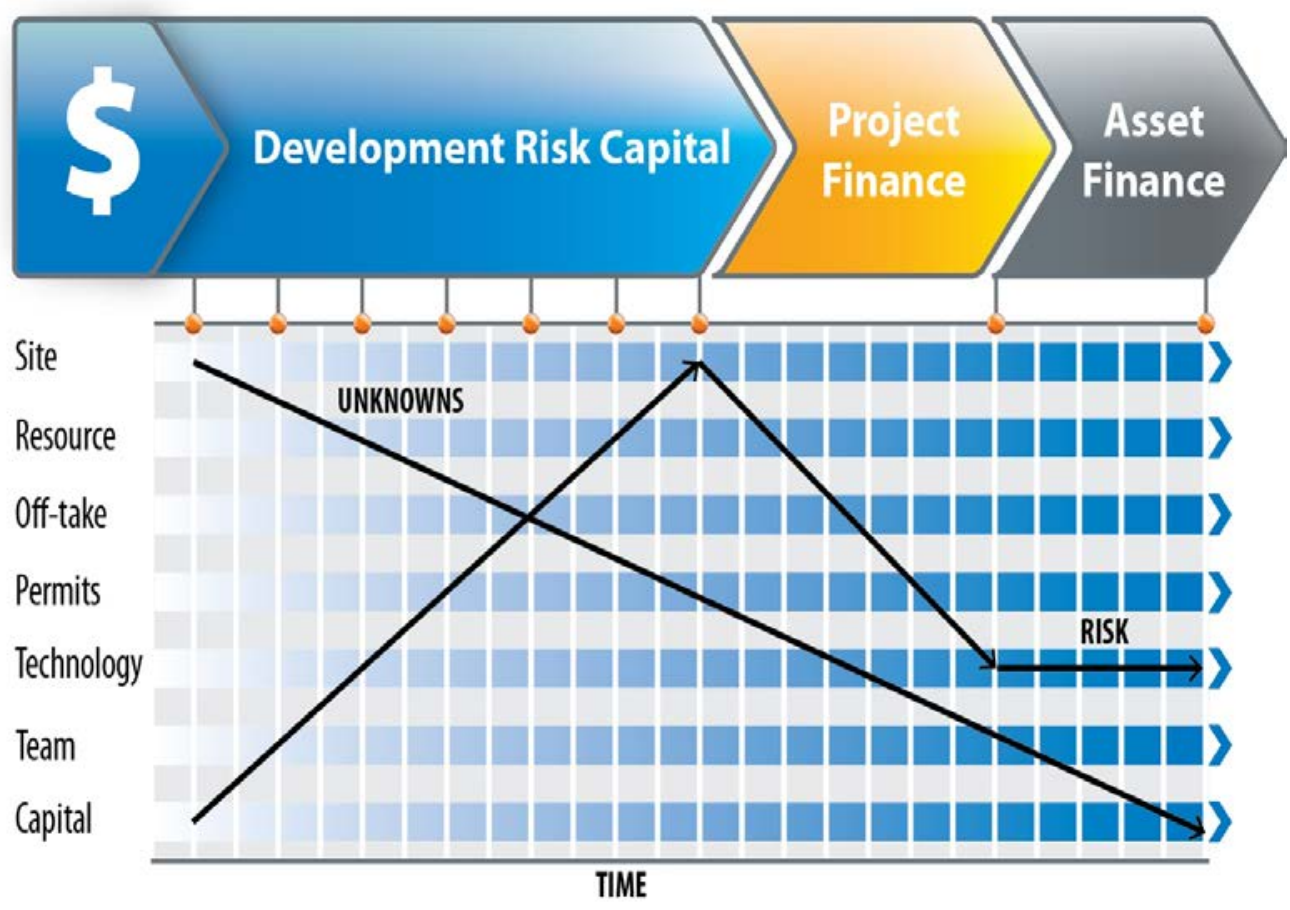

Figure 19. Project stages with risks and unknowns 


\section{Summary of Recommendations}

This section summarizes priority projects that have been identified through NREL's site visit, research, and analysis. The projects are then linked to the corresponding objectives with the RMI's NEPEAP volumes I and II to determine a list of high potential projects for action.

Table 17. Summary of priority projects for action

\begin{tabular}{|c|c|c|}
\hline Priority Projects & $\begin{array}{l}\text { Link to RMI National Energy } \\
\text { Plan Objectives (Volume I) }\end{array}$ & $\begin{array}{l}\text { Tie to RMI NEP Action Plan } \\
\text { Objectives (Volume II) }\end{array}$ \\
\hline $\begin{array}{l}\text { Perform independent analysis of wind } \\
\text { and solar data collected on Jaluit, } \\
\text { Wotje, and Majuro. } \\
\text { - Use existing wind and solar data } \\
\text { collected from the meteorological } \\
\text { towers on Wotje, Jaluit, CMI, and } \\
\text { other sources on Majuro, and as } \\
\text { needed, analyze the data and } \\
\text { compile into a format that can be } \\
\text { used for future feasibility studies and } \\
\text { in the development of potential } \\
\text { resource maps, RFPs, and tenders. } \\
\text { Conduct analyses for Ebeye, Jaluit, } \\
\text { Wotje and Rongrong to estimate } \\
\text { technical and economic options for } \\
\text { hybrid renewable/ diesel/storage } \\
\text { systems. Estimate possible } \\
\text { equipment configurations, capital, } \\
\text { and life cycle costs of hybrid } \\
\text { systems, and suggested actions for } \\
\text { implementation. Majuro ratepayers } \\
\text { subsidize energy use on outer island } \\
\text { systems, thus cost reductions on } \\
\text { outer islands benefit entire country. }\end{array}$ & $\begin{array}{l}\text { Volume I, Section 9, Page 23: } \\
\text { - } \quad \text { Improve capacity within the } \\
\text { RMI to plan, develop, } \\
\text { implement, and manage } \\
\text { renewable energy systems } \\
\text { (small- and medium-scale } \\
\text { rural; large-scale urban) } \\
\text { - Provide } 20 \% \text { of electrical } \\
\text { energy through indigenous } \\
\text { renewable resources by } \\
2020 \\
\text { - Outer island energy } \\
\text { development to be through } \\
\text { indigenous energy sources } \\
\text { where technically practical } \\
\text { and economically attractive }\end{array}$ & $\begin{array}{l}\text { Volume II, Renewable Energy, } \\
\text { Pages 25-32: } \\
\text { Strategy 1. Determine the } \\
\text { indigenous energy resources that } \\
\text { are available for development. } \\
\text { Note: The specific actions listed } \\
\text { under this strategy called for } \\
\text { installation of two met towers on } \\
\text { Majuro. To NREL's knowledge, } \\
\text { the only met towers installed } \\
\text { were the ones on the outer atolls } \\
\text { of Jaluit and Wotje. CMI has } \\
\text { also been recording data. DOD } \\
\text { is in the process of installing a } \\
\text { tower on Kwajalein, but it has } \\
\text { not yet been installed. }\end{array}$ \\
\hline $\begin{array}{l}\text { Evaluate the potential for biofuels. } \\
\text { Build on previous studies that have } \\
\text { been conducted. } \\
\text { - Perform life cycle analysis of } \\
\text { substituting a portion of diesel fuel } \\
\text { with locally grown and processed } \\
\text { coconut oil. The study to include a } \\
\text { systems view of using locally } \\
\text { produced coconut oil for power } \\
\text { production in the context of energy } \\
\text { needs, and impact on the local } \\
\text { economy in terms of not just energy } \\
\text { costs, but the net benefit of local } \\
\text { expenditures versus export of cash, } \\
\text { creation of local jobs, and outer island } \\
\text { economic viability. } \\
\text { Evaluate options to produce oil on } \\
\text { outer islands. }\end{array}$ & $\begin{array}{l}\text { Volume I, Section 5, Page 13: } \\
\text { Develop local biofuel } \\
\text { industry where economically, } \\
\text { environmentally, and } \\
\text { financially practical } \\
\text { Volume I, Section 6, page 16: } \\
\text { Independent study of the } \\
\text { viability of alternatives to } \\
\text { diesel fuel for power } \\
\text { generation where } \\
\text { economically sound (e.g., } \\
\text { coconut oil, heavy fuel oil, } \\
\text { grid-connected solar) }\end{array}$ & $\begin{array}{l}\text { Volume II, Petroleum Fuels, } \\
\text { Page 11: } \\
\text { Objective 2.6. Arrange } \\
\text { independent study of the } \\
\text { technical, economic, } \\
\text { environmental (including } \\
\text { greenhouse gas implications), } \\
\text { and financial practicality of } \\
\text { developing local coconut-based } \\
\text { biofuels with varying } \\
\text { assumptions regarding the } \\
\text { landed cost of petroleum fuels. } \\
\text { Volume II, Renewable Energy, } \\
\text { Page 37: } \\
\text { Strategy 7. Perform feasibility } \\
\text { study and project design for } \\
\text { biofuel development. }\end{array}$ \\
\hline $\begin{array}{l}\text { Conduct an energy audit for Tobolar. } \\
\text { - Conduct detailed energy audits of } \\
\text { Tobolar. CMI, MRD, and MEC staff } \\
\text { invited to participate in the audits to } \\
\text { improve local capacity. }\end{array}$ & $\begin{array}{l}\text { Volume 1, Section } 8 \text {, page 20: } \\
\text { - Train government, MEC, and } \\
\text { private sector in energy } \\
\text { auditing and energy } \\
\text { management techniques }\end{array}$ & $\begin{array}{l}\text { Volume II, Energy Efficiency, } \\
\text { Page 22: } \\
\text { Strategy 3: Carry out energy } \\
\text { audits on all government } \\
\text { facilities. }\end{array}$ \\
\hline
\end{tabular}




\begin{tabular}{|c|c|c|}
\hline Priority Projects & $\begin{array}{l}\text { Link to RMI National Energy } \\
\text { Plan Objectives (Volume I) }\end{array}$ & $\begin{array}{l}\text { Tie to RMI NEP Action Plan } \\
\text { Objectives (Volume II) }\end{array}$ \\
\hline $\begin{array}{l}\text { Provide technical support and training } \\
\text { to MRD's Energy Planning Division } \\
\text { (EPD) staff. } \\
\text { Technical and policy support to EPD } \\
\text { staff on a variety of topics, based on } \\
\text { EPD's specific needs and requests. } \\
\text { This support could take the form of } \\
\text { white papers, technical analysis, } \\
\text { action planning, development of } \\
\text { energy sector data management } \\
\text { tools, webinars, and targeted } \\
\text { technical training. } \\
\text { Assist EPD with updates to Energy } \\
\text { Action Plan. } \\
\text { Assist EPD with developing energy } \\
\text { project tracking tools, such as the } \\
\text { wedge model and energy tracking } \\
\text { spreadsheets developed as part of } \\
\text { the RMl assessment effort. }\end{array}$ & $\begin{array}{l}\text { Volume 1, Section 4, Pages 10- } \\
\text { 11: } \\
\text { - } \quad \text { EPD develops the level of } \\
\text { skills necessary to review, } \\
\text { update, and implement } \\
\text { energy policy framework } \\
\text { - EPD uses its limited human } \\
\text { and financial resources } \\
\text { effectively, concentrating on } \\
\text { important, practical, and } \\
\text { achievable goals } \\
\text { MRD influences key energy } \\
\text { decisions, shifting RMI } \\
\text { toward more sustainable and } \\
\text { rational energy use } \\
\text { - National energy database } \\
\text { developed and regularly } \\
\text { updated }\end{array}$ & $\begin{array}{l}\text { Volume II, Energy Policy } \\
\text { Administration and } \\
\text { Implementation, Pages 5-8: } \\
\text { - Objective 1.6. Develop } \\
\text { energy-related performance } \\
\text { measures for government } \\
\text { ministries and agencies, } \\
\text { internally or with technical } \\
\text { assistance if needed. } \\
\text { Objective 2.1. Develop MRD } \\
\text { EPD Annual Work Plan, } \\
\text { based on this action plan, } \\
\text { with clear objectives, } \\
\text { priorities, persons } \\
\text { responsible, and timeframe. } \\
\text { If necessary, review and } \\
\text { amend Action Plan according } \\
\text { to resources available. } \\
\text { Objective 2.2. Develop an } \\
\text { energy sector database (or } \\
\text { databases) suitable for } \\
\text { comprehensive planning and } \\
\text { implementation of energy } \\
\text { activities, with regular } \\
\text { updates. }\end{array}$ \\
\hline $\begin{array}{l}\text { Promote RE/EE options for Ebeye. } \\
\text { - Analysis for Ebeye to provide } \\
\text { preliminary estimates of options for } \\
\text { deployment of renewable energy } \\
\text { systems. } \\
\text { Energy audits of government facilities } \\
\text { on Ebeye, especially the hospital, } \\
\text { water, and sewage plants, and } \\
\text { schools. Identify options for solar hot } \\
\text { water, efficiency, and renewable } \\
\text { energy technologies } \\
\text { Seek win-win opportunities between } \\
\text { the RMI government, Department of } \\
\text { the Interior, and U.S. Army to support } \\
\text { KAJUR with energy sector priorities in } \\
\text { Ebeye. }\end{array}$ & 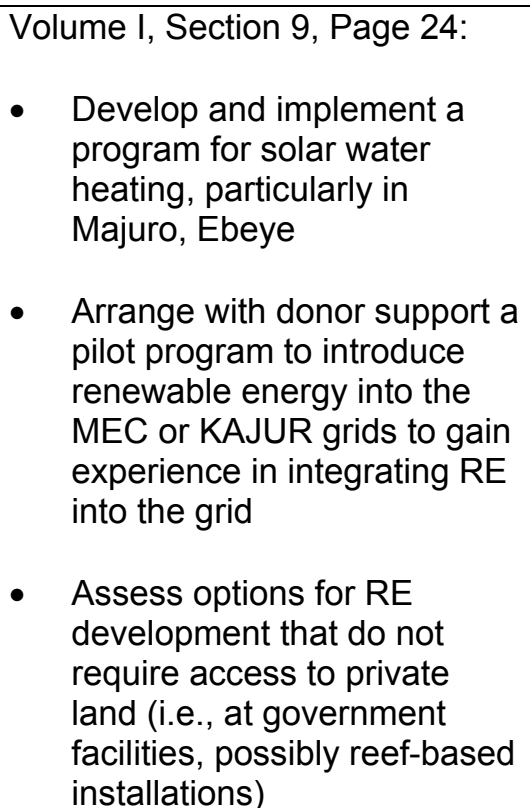 & $\begin{array}{l}\text { Volume II, Renewable Energy, } \\
\text { Pages 29-32: } \\
\text { - Strategy 1. Determine the } \\
\text { indigenous energy resources } \\
\text { that are available for } \\
\text { development. } \\
\text { - Strategy 6. Replace electric } \\
\text { water heaters with solar } \\
\text { water heaters in existing } \\
\text { buildings and use solar water } \\
\text { heaters for new buildings. }\end{array}$ \\
\hline $\begin{array}{l}\text { Provide technical support for RFP } \\
\text { issuance by MEC and/or KAJUR. } \\
\text { - Technical backstopping to MEC and } \\
\text { KAJUR when issuing specific RFPs } \\
\text { to help ensure that quality proposals } \\
\text { are received. } \\
\text { - Technical review and comments on } \\
\text { proposals received, including }\end{array}$ & $\begin{array}{l}\text { Volume I, Section 5, Page 13: } \\
\text { Provide neutral advice on } \\
\text { tendering and develop } \\
\text { expertise within the } \\
\text { government on appropriate } \\
\text { tendering }\end{array}$ & $\begin{array}{l}\text { Volume II, Petroleum and Liquid } \\
\text { Fuels, Page 11: } \\
\text { - Tendering and contracts. }\end{array}$ \\
\hline
\end{tabular}




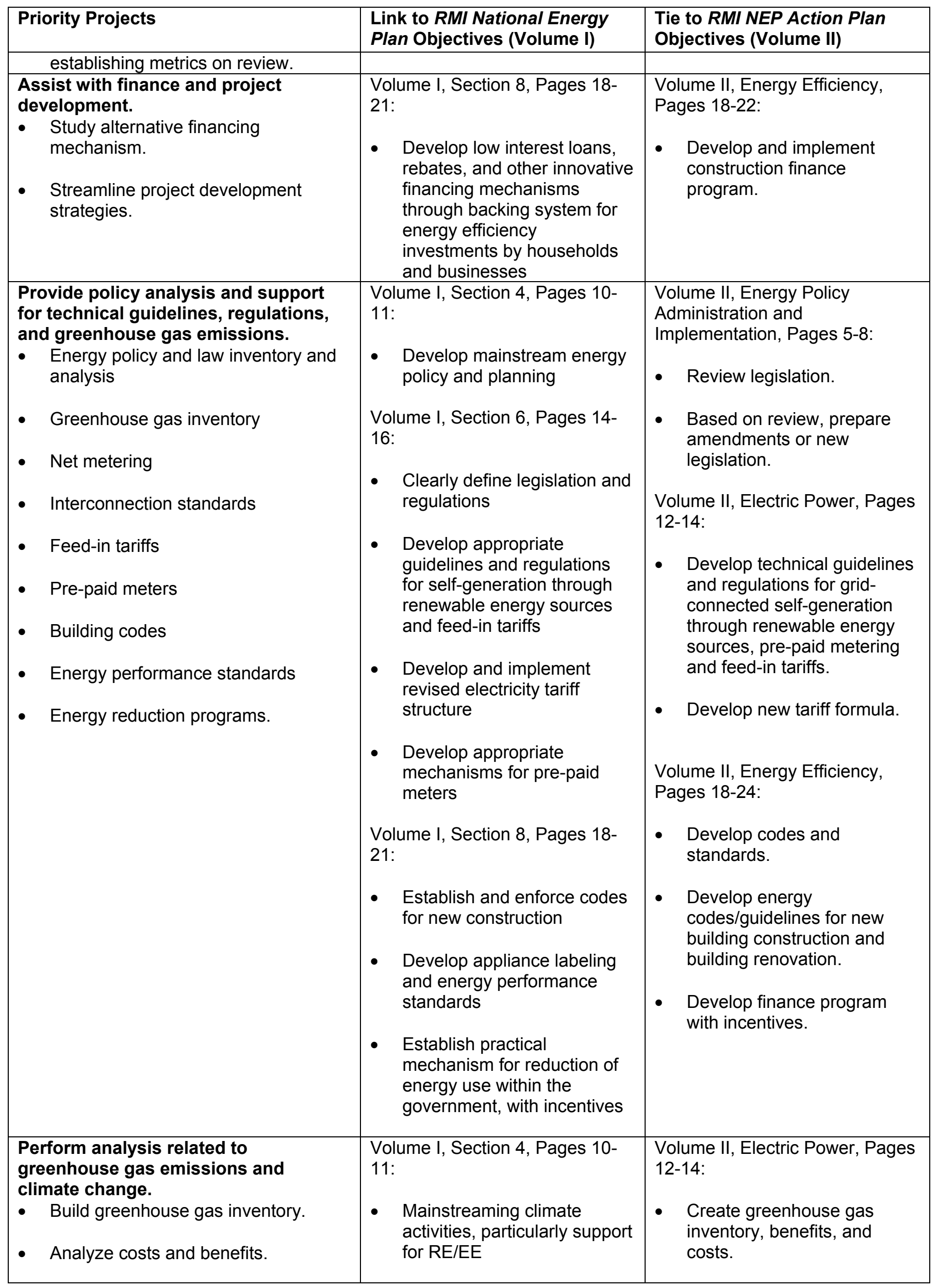




\begin{tabular}{|c|c|c|}
\hline Priority Projects & $\begin{array}{l}\text { Link to RMI National Energy } \\
\text { Plan Objectives (Volume I) }\end{array}$ & $\begin{array}{l}\text { Tie to RMI NEP Action Plan } \\
\text { Objectives (Volume II) }\end{array}$ \\
\hline $\begin{array}{l}\text { Assist with government energy audits } \\
\text { with training. } \\
\text { - Perform government-building energy } \\
\text { audits. } \\
\text { - Run training program concurrently. }\end{array}$ & 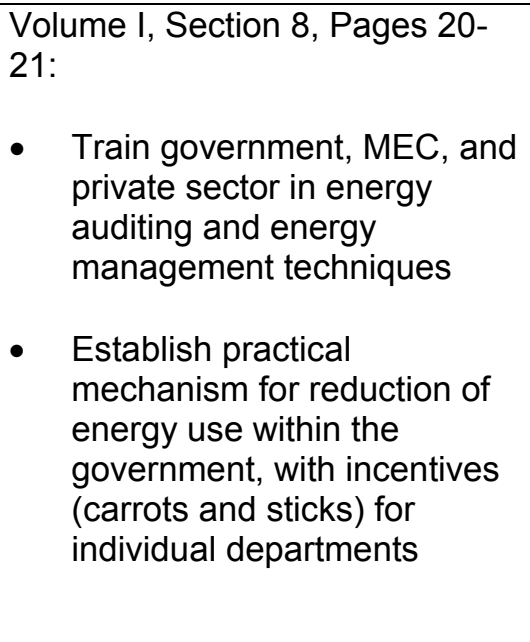 & $\begin{array}{l}\text { Volume II, Energy Efficiency, } \\
\text { Page 22: } \\
\text { Strategy 3.1. Engage a } \\
\text { professional energy audit } \\
\text { firm experienced in tropical } \\
\text { facility energy audits to } \\
\text { carry out a detailed energy } \\
\text { audit of all government } \\
\text { buildings, and water system } \\
\text { and sewage system facilities, } \\
\text { and recommend changes } \\
\text { including priorities, } \\
\text { investment required, and } \\
\text { payback periods for each } \\
\text { recommended action. }\end{array}$ \\
\hline $\begin{array}{l}\text { Education and Outreach } \\
\text { - Encourage energy literacy. }\end{array}$ & $\begin{array}{l}\text { Volume I, Section 8, Pages 18- } \\
\text { 21: } \\
\text { - Implement public awareness } \\
\quad \text { campaign. }\end{array}$ & $\begin{array}{l}\text { Volume II, Energy Efficiency, } \\
\text { Pages 18-24: } \\
\text { - Perform public events and } \\
\text { information services. } \\
\text { - Encourage student } \\
\text { participation in EE. }\end{array}$ \\
\hline
\end{tabular}




\section{Conclusion: Implementing Actions}

Globally, the science of renewable energy and energy efficiency technologies has greatly advanced. Technical opportunity and strategies for building the capabilities to guide deployment of commercial alternative energy applications have been reported within this text. Transforming energy systems to achieve aggressive economic, environmental, and security goals requires a comprehensive approach.

Island communities, such as the RMI, can realize a sustainable future based on clean, cost-effective, and secure resources. The next major step in the energy transformation process is transforming the analyses, assessments, and planning into observable action. Accomplishing this requires many smaller steps, including establishing which projects are of the highest priority, detailing the actions involved in successful implementation, identifying project responsibility, identifying and acquiring funding, setting project dates and milestones, setting accountable measures, and following through. In addition, addressing barriers and challenges previously mentioned will improve the chances of project success and long-term economic development.

Together, the NEPEAP and this assessment categorize the higher priority energy projects for the RMI. Figure 20 below highlights the projects that are identified in both the NEPEAP and this report. The projects that overlap are higher priority and should be considered for action first. Working closely with the RMI, NREL will continue to assist as appropriate and as approved by OIA on priority projects that enable the RMI to implement their NEPEAP goals.

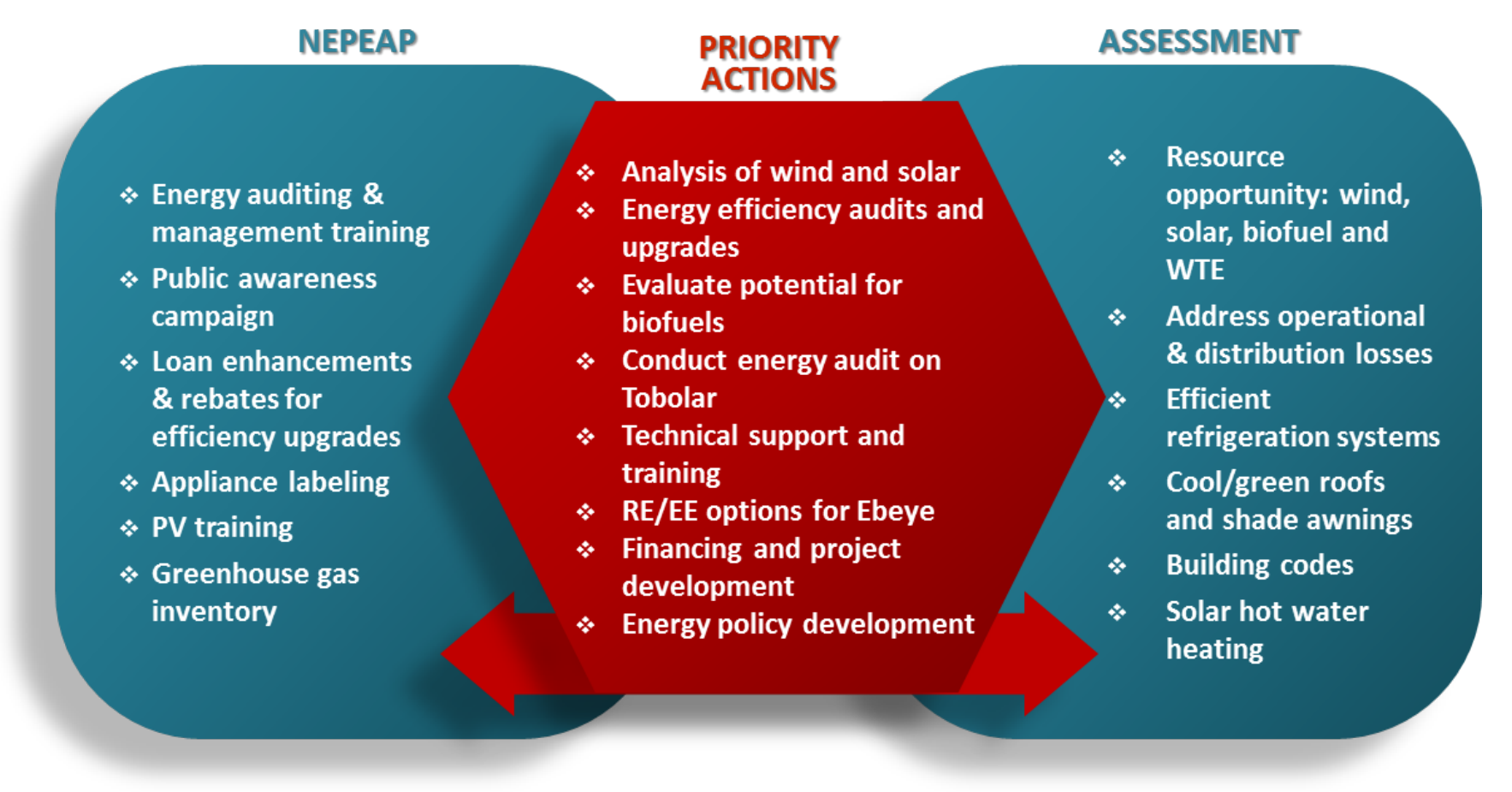

Figure 20. Energy projects identified in the RMI NEPEAP and by NREL's assessment team 


\section{Appendix: Glossary of Energy-Related Terms}

Amp (ampere or A). The SI base unit of electric current. The ampere is a measure of the amount of electric charge passing a point in an electric circuit per unit time with $6.241 \times 1018$ electrons, or one coulomb per second constituting one ampere. In practical terms, this means that measures of a constant current will be defined in amperes and the flow of charge through a circuit over a period of time will be defined in coulombs. In this way, amperes can be viewed as a flow rate (i.e., number of particles [charged] transiting per unit time), and coulombs simply as the number of particles.

Availability factor. The percentage of a given time period during which a power plant is potentially able to produce electrical power. Maintenance requirements are the primary reason for lower availability factors. Solar and wind power plants have very high availability factors (about $98 \%$ for wind turbines and approaching 100\% for solar power plants) because they need little maintenance. However, they have relatively low capacity factors compared to most thermal power plants because their fuel (sunlight and wind) is not always available. Some definitions of availability factor incorporate fuel availability into the calculation, thereby reducing the availability factor of wind and solar plants to roughly the same percentage as their capacity factor.

Average demand: The demand on, or the power output of, an electric system or any of its parts over an interval of time, determined by dividing the number of kilowatt hours by the number of hours in the interval.

Avoided cost. The total economic costs (consisting of the capital and operating costs to provide generation capacity and fuel, transmission, storage, distribution, and customer service) to serve end-use energy requirements using a given set of resources. These costs are referred to as "avoided" when an alternative set of resources is used to serve requirements. A better term for these costs would be "avoidable cost." Avoided cost must be determined to assess the cost-effectiveness of potential supplyside and demand-side resources. (See: differential total resource cost method.)

Base load. The minimum average electric load over a given period of time.

Base load unit/station. An electric generating facility designed for nearly continuous operation at or near full capacity to serve base load. Base load generating stations are operated to meet all, or part, of the minimum load demand of an electric system.

Baseline market characterization. The mix of end use fuels and end use technologies, including their associated costs, energy efficiencies, and load factors expected to occur in each year of the planning period in the absence of expenditures on demand-side management programs.

Benefit-cost ratio. The ratio of the value of a demand-side management measure's energy savings to its installed cost. The energy savings value is based on the utility's avoided cost.

Billing demand: The demand for which a customer is billed. Because billing demand is based on the provisions of a rate schedule or contract, it does not necessarily equal the actual measured demand of the billing period.

British thermal unit (Btu). A commonly used unit of energy, especially for fuels or heat. A kilowatthour is equal to approximately 3,412 Btu.

Building envelope. The roof, floor, walls, doors, and windows that separate the inside of a building from the outside. Also known as building shell.

Capacity. The maximum quantity of electrical output for which a supply system or component is rated. 
Capacity expansion plan. The schedule of power supply investments that is planned in order to meet forecasted future electricity demand.

Capacity factor. The ratio of the average output of an electric power generating unit for a period of time to the capacity rating of the unit during that period. A capacity factor of $50 \%$ means that, for example, a power plant produces on average half of the electricity that it could have produced if operated continuously at its full capacity rating.

Capacity rating. A measure of the electrical power that a piece of equipment can be expected to produce or use if used fully under normal (non-emergency) conditions.

Capacity value. The contribution of a supply resource to the maximum capacity of an electric system. Capacity value is a measure of the reliability and predictability of a resource.

Capital recovery rate. This is the rate of return paid on the debt plus the rate of return paid on the principal.

Cogeneration. The sequential production of electricity and useful thermal energy from the same energy source. Natural gas is a favored fuel for combined-cycle cogeneration units, in which waste heat is converted to electricity. Also called combined heat and power (CHP).

Coincident demand. The rate of electricity demand of a customer or group of customers at the time of an electric system's total peak demand.

Coincident peak. Customer demand at the time of electric system peak demand.

Combined cycle generating plant. A generating plant using one or more combustion turbines in combination with a steam cycle to produce energy at a higher overall efficiency than a combustion turbine alone. In one combined-cycle configuration, hot exhaust gases from the combustion turbine are used to raise steam. The steam is then passed through a turbine, which turns a generator. Combinedcycle plants are fueled with oil, natural gas, and sometimes coal that has been converted to a gas ("gasified").

Combined heat and power. See: cogeneration.

Combustion turbine (CT). Sometimes called gas turbines, these devices burn oil or natural gas, converting the heat energy from the burning fuel to mechanical energy by directing the flow of combustion gasses against rows of radial blades fastened to a central shaft. The central shaft is connected to an electric generator.

Commercial losses. See: nontechnical losses.

Commercial sector. Nonresidential facilities which provide services, including retail, wholesale, finance, insurance, and public administration.

Conservation. A reduction in energy use.

Constant dollars. See: real monetary values.

Cost-effective. The net present value (NPV) of the benefits of the potential resource under consideration over the planning period are greater than the NPV of its costs. Cost-effectiveness is always measured relative to an alternative. Cost-effectiveness can be measured from a variety of perspectives, which vary in terms of the specific costs and benefits included in the calculation. 
Cost of saved energy (CSE). This is an indicator of the cost of saving electricity through a given type of demand-side management measure. CSE is calculated by dividing the additional cost of the efficiency measure (relative to standard technologies) by the electric savings such and efficiency measure produces.

Coulomb (C). A coulomb is the International System of Units (SI) unit of electric charge. One coulomb is the amount of charge accumulated in one second by a current of one amp.

Customer. An individual or entity that purchases electric service as one account under one contract or rate schedule. If service is supplied to a customer at more than one location, each location is generally counted a separate customer, unless the locations are served under one billing account.

Customer charge. An amount paid periodically by a customer for electric service, exclusive of demand and/or energy consumption. It is often based upon utility costs incurred for metering, meter reading, billing of customers, etc.

Customer class. A group of customers with similar characteristics, such as economic activity or level of electricity use.

Demand. The rate at which electricity is delivered by a system or part of a system, or to a load point or set of loads. It is measured in kilowatts, kilovolt-amperes, or other suitable unit at a given instant or averaged over a designated period of time.

Demand charge. The portion of the charge for electric service that is based on billing demand under an applicable rate schedule.

Demand forecast. Projected demand for electric power. A load forecast may be short-term (e.g., 15 minutes) for system operation purposes, long-term (e.g., five to 20 years) for generation planning purposes, or for any range in between. Load forecasts may include peak demand (kilowatts), energy (kilowatt-hours), reactive power (kilovolt-amperes reactive), and/or load profile. Forecasts may be made of total system load, transmission load, substation/feeder load, individual customers, loads, or appliance loads.

Demand-side management (DSM). Actions undertaken by a utility to change the level or timing of energy use on the customer side of the electricity meter, generally with the intention of optimizing existing and planned generation and transmission assets on the utility side of the meter. It encompasses utility-initiated actions to improve energy efficiency, increase energy conservation, and reduce peak electricity demand. Examples include rebates, incentives, and utility investments that improve building shell insulation and the efficiency of heating and cooling systems, and rate structures that shift demand from times of peak energy use to off-peak hours.

DSM includes other load management approaches, such as direct load control systems that enable the grid operator to regulate the electricity used by individual appliances or equipment on customer premises (usually residences), and contractual arrangements that allow the utility to reduce demand by specific customers (usually businesses) through direct action by the grid operator (remote tripping) or by the customer voluntarily taking action to reduce demand when requested by the grid operator.

DSM is sometimes defined to include utility incentives to encourage electricity generation by customers because it reduces the need for the utility to invest in power plants or transmission and distribution networks. This definition of DSM includes solar photovoltaic (PV) or other distributed generation systems installed on a customer's property, but does not include PV or other distributed generators installed on the transmission or distribution grid. 
DSM refers only to energy and load-shape modifying activities that are undertaken in response to utilityadministered programs, such as a utility incentive to customers encouraging them to buy more energyefficient light bulbs. It does not refer to changes arising from normal operation of the market (such as the independent decision by a customer to buy such light bulbs because electricity is expensive) or from government-mandated energy efficiency standards.

Distribution. Electricity distribution is the final stage in the delivery of electricity to end users. A distribution system's network carries electricity from the transmission system and delivers it to consumers. Typically, the network would include medium-voltage (1kilovolt [kV] to $72.5 \mathrm{kV}$ ) power lines, substations, and pole-mounted transformers, and low-voltage (less than $1 \mathrm{kV}$ ) distribution wiring and sometimes meters.

Distributed generation (DG). Distributed generation is an approach that employs small-scale technologies to produce electricity close to the end users of power. Distributed generation technologies often consist of modular and/or renewable-energy generators, and they offer a number of potential benefits. In many cases, distributed generators can provide lower-cost electricity and higher power reliability and security with fewer environmental consequences than traditional power generators can. Distributed generation for renewable energy can also help offset the intermittent power generation that is inherent in wind and solar technologies. In contrast to the use of a few large-scale generating stations located far from load centers - the approach used in the traditional electric power paradigm - distributed generation systems employ numerous, but small, plants and can provide power onsite with little reliance on the distribution and transmission grid. DG technologies yield power in capacities that range from a fraction of a kilowatt to about 100 megawatts (MW). Utility-scale generation units generate power in capacities that often reach beyond 1,000 MW.

Demand-side measure. Any hardware, equipment, device, or practice, which is installed or instituted resulting in increased efficiency in the utilization of energy at a facility.

Demand-side resource. The energy service needs met through a demand-side management measure or program.

Differential total resource cost method. A method for computing avoided costs for a potential resource, whereby the year-by-year total resource costs for a least-cost supply plan, excluding the potential resource, are subtracted from the year-by-year total resource costs of a least-cost supply plan, including the potential resource. This method ensures consistency with integrated resource planning as a whole when the TRC test is utilized.

Dispatch order. The order of priority in which each electric generation unit is selected for operation during a given time interval.

Dispatching. The operating control of an integrated electric system to assign load to specific generating units as loads vary, to control operations of high-voltage lines and substations, and to operate the interconnections with other electric systems, including energy transactions.

Diversity. The diversity among customers' demands, which creates variations among the loads in distribution transformers, feeders, and substations at a given time. Load diversity is the difference between the sum of the maximum of two or more individual loads and the coincident or combined maximum load. It is usually measured in kilowatts.

DSM assessment and selection. Identifying and evaluating key customer or market and utility considerations, and completing a cost/benefit analysis of these. 
Demand-side management implementation. Pilot and full-scale implementation or execution of the demand-side management plans and programs.

Demand-side management monitoring and evaluation (M\&E). Measuring the outcomes of program implementation and providing feedback on results.

Demand-side management objectives. Broad utility demand-side management objectives, including load shape objectives.

Economic dispatch. A dispatch order based on realizing the most economical production of electricity for customers.

Economic potential. With regard to demand-side management, the total electricity savings (energy and demand) that would be realized if all demand-side management measures that are cost-effective from the total resource cost perspective were to be implemented.

Electrical energy. The energy of moving electrons (i.e., the amount of work accomplished by flowing electricity), usually measured in kilowatt-hours or megawatt-hours.

Electrical generating capacity. The maximum power-generating capacity of a power plant (usually measured in kilowatts or megawatts). Also referred to as nameplate capacity.

Emission factor. The ratio of emissions to energy produced or fuel consumed, denominated in units of tons of emissions per unit of energy.

End use. Useful work, such as light, heat, and cooling, which is produced by electricity or other forms of energy.

Energy. The capacity for doing work (potential energy) or the total amount of work done (kinetic energy). These two categories of energy are interconvertible because stored energy (such as the water behind a dam) becomes kinetic energy (such as that water flowing through a hydropower turbine) when we use it. The basic unit of energy is the joule $(\mathrm{J})$, although different forms of energy express this unit slightly differently. Energy can be used to change the position, physical composition, or temperature of an object. The energy of electrons changing position (electricity) is expressed in watt-seconds (one joule is the work required to produce one watt of power for one second). Heat energy is expressed in British thermal units $(1 \mathrm{Btu} \sim 1,055 \mathrm{~J})$.

Energy audit. Analysis of a facility's electricity and other energy usage, often including recommendations to alter the customer's electric demand or reduce energy usage. An audit usually is based on a visit by an energy analyst or engineer to the home, building, or manufacturing or agricultural facility.

Energy charge. The charge for electric service based upon the amount of electric energy (kilowatthours) consumed and billed under an applicable rate schedule. See also customer charge and demand charge.

Energy conservation. The process of using less energy by reducing or going without a service. Energy conservation typically requires a change in behavior or not using an existing technology (e.g., turning off a light, using the stairs instead of taking the elevator, or turning up the thermostat on an air conditioner). Popular approaches to accomplishing energy conservation goals include: (1) educating people about how to conserve energy, and (2) implementing non-energy-consuming technologies, such as cool roofs, which reduce the need for air conditioning. 
Energy efficiency. The process of using less energy to provide the same service, or using the same amount of energy to provide more services. Energy efficiency typically requires the use of a different energy technology or using existing technology in a different way. For example, a compact fluorescent light or light-emitting diode bulb is more energy efficient than a traditional tungsten incandescent light bulb because it produces the same amount of light (measured in lumens), using significantly less electrical energy.

Energy efficiency program. A demand-side management program aimed at reducing overall electricity consumption (kilowatt-hours). Such savings are generally achieved by substituting technically more efficient equipment to produce the same level of end use services with less electricity. Compare with conservation; contrast with load management.

Energy-limited resource. A supply resource (e.g., hydro) of which the total annual energy output is limited, regardless of how much rated capacity is available.

Environmental impacts. Physical impacts on the environment (air, land and water) associated with the full fuel cycle (i.e., development, extraction, processing, transportation, storage and combustion). If these impacts are measured relative to a specific point in the fuel cycle (e.g., the point of combustion), they may be categorized as upstream or downstream (i.e., upstream of this reference point, or downstream of this reference point).

Evaluation. See demand-side management monitoring and evaluation.

Externality. A cost or benefit from production or consumption that is not accounted for in market prices. Costs and benefits that do not have market value, and thus current or projected prices, are externalities. For example, the costs of damage to human health from certain air pollutants are negative environmental externalities.

Fixed charge rate (levelized). The annual interest, depreciation, taxes and other costs of ownership of an item of property or capital equipment, expressed as a fraction of the capital cost of the item. For example, a fixed charge rate of $15 \% / y r$. means that the annual fixed charge on a power plant costing $\$ 1,000,000$ would be $\$ 150,000$, allowing the capital cost of the plant to be paid over a number of years, rather than all at once. See also capital recovery rate.

Fixed operation and maintenance $(O \& M)$ costs. Annual costs incurred for operating and maintaining a power plant regardless of the amount of energy it produces each year. These costs are often expressed in dollars per kilowatt of capacity per year.

Free rider. A customer who would have implemented a demand side measure even in the absence of a demand-side management program but who takes advantage of the monetary incentives offered by the demand-side management program. There are various degrees to which a customer may be a free rider.

Gigawatt (GW). One gigawatt equals 1 billion watts, 1 million kilowatts, or 1 thousand megawatts.

Gigawatt hour (GWh). One gigawatt hour equals one billion watt hours.

Heat rate. Generating unit efficiency, usually expressed in Btu of input energy required to produce a kilowatt-hour of electrical output in a given power plant. See also British thermal units.

HVAC. An acronym for heating, ventilating, and air conditioning services required in buildings, or for the equipment used to provide HVAC services. 
Hydro or hydroelectric power. A generating station or power or energy output in which the device generating the electricity is driven by water power.

Incremental cost. The difference in costs between two alternatives; for example, between that of an efficient technology or measure and the standard technology.

Instantaneous peak demand. The demand at the instant of greatest load, usually determined from the readings of indicating meters or graphic meters.

ISO. (1) The International Organization for Standardization. The ISO is a worldwide federation of national standards bodies from 130 countries. (2) Acronym for Independent System Operator of a transmission system that services multiple power suppliers.

Integrated demand. The summation of continuously varying instantaneous demands during a specified demand interval.

Joule (J). A Joule is the International System of Units (SI) unit of work or energy, defined to be the work done by a force of one newton (SI unit of force) acting to move an object through a distance of one meter in the direction in which the force is applied. Equivalently, one joule is the kinetic energy of a mass of two kilograms moving at a velocity of $1 \mathrm{~m} / \mathrm{s}$.

Kilowatt (kW). A measure of electrical power equal to one thousand watts.

Kilowatt-hour (kWh). A measure of electrical energy supplied, equal to 1,000 watts over a period of one hour.

Levelized cost. The uniform annual cost that results in the same net present value over the planning horizon as the stream of actual annual average costs. An example of a levelized cost is a monthly mortgage payment.

Line losses. Kilowatt-hours and kilowatts lost in the transmission and distribution lines under specified conditions.

Load. The amount of electric power consumed at any specified point or points on a system. Load originates primarily in the power consuming equipment of the customers.

Load duration curve. A graph showing a utility's hourly demand, sorted by size, as well as by the amount of time a given level of demand is exceeded during the year.

Load factor. The ratio of the average load in kilowatts supplied during a given period to the peak or maximum load in kilowatts occurring during that period. Load factor may be calculated for a customer, customer class, or the entire electric system.

Load forecast. See demand forecast.

Load management. The controlling, by rescheduling or direct curtailment, of the power demands of customers or groups of customers in order to reduce the total load that a utility must meet at times of peak demand. Load management strategies are designed to either reduce or shift demand from on-peak to off-peak, while conservation (see: energy efficiency) strategies reduce usage over larger multi-hour periods. Load management may take the form of normal or emergency procedures. Utilities often encourage load management by offering customers a choice of service options with varying price incentives.

Load shape. The time-varying usage pattern of customer demand for energy. 
Load shedding. The turning off of electrical loads to limit peak electrical demand.

Load shifting. Shifting load from peak to off-peak periods. Applications include use of storage water heating, storage space heating, cool storage, and customer load shifts to take advantage of time-of-use or other special rates.

Loss of load probability (LOLP). A measure of the probability that system demand will exceed available capacity during a given period.

Lost revenues. Utility income that is lost through reduced sales due to a demand-side management or energy efficiency program.

Marginal cost of energy. The cost of providing an incremental unit of energy.

Marginal cost of capacity. The cost of meeting an incremental unit of peak-demand.

Marginal resource. The most expensive resource, in terms of short-run marginal (fuel and operating) cost, needed at a given time.

Market barriers. Forces in the marketplace of goods and services which inhibit customer selection based on economic criteria and restricted access to capital.

Market potential. An estimate of energy savings that adjusts the economic potential of demand-side management to account for the likely acceptance by customers of demand-side management programs or other market interventions.

Maximum demand. The greatest demand that occurs during a specified period of time.

Meter. An electric meter or energy meter is a device that measures the amount of electrical energy consumed by a residence, business, or an electrically powered device.

Megawatt (MW). A measure of electrical power equal to one million watts.

Megawatt-hour (MWh). A measure of electrical energy supplied, equal to 1,000,000 watts over a period of one hour.

Monitoring and evaluation. The process of collecting and analyzing data and drawing conclusions about the performance of supply- and demand-side resources.

Net present value (NPV). The present value of the future cash flows of an investment less the investment's current and future costs.

Net revenue loss. The portion of revenue requirements, net of avoided costs, a utility does not recover from ratepayers between rate cases because of the change in customer consumption attributable to its DSM programs.

Nominal currency values. Dollar or other currency values given in nominal terms are taken at face value. Compare with: real currency values.

Nominal levelized cost. The uniform cost of electricity, in mixed current dollars, for which the present value of the cost of electricity produced over the life of the plant is equal to the present value of the costs of the plant. 
Non-coincident demand: The peak demands of subgroups of customers that do not coincide with system peak demand.

Nontechnical losses. Commercial losses from theft of electricity through unauthorized connections, tampering with meter reading, metering errors, etc.

Off-peak energy. Electricity supplied during periods of relatively low system demand.

On-peak energy. Electricity supplied during periods of relatively low system demand.

Peak demand. The maximum rate of electricity consumption, expressed in gigawatts. May be expressed for groups of electricity users or the whole system, and by season (summer or winter) or annually. See: demand. Also called peak load.

Peak load. See: demand.

Peaking unit, or peaker. A generating station that is normally operated to provide power during maximum load periods.

Photovoltaic (PV). PV materials and devices convert sunlight into electrical energy, and PV cells are commonly known as solar cells. Photovoltaics can literally be translated as light electricity. Commonly known as solar cells, individual PV cells are electricity-producing devices made of semiconductor materials. PV cells come in many sizes and shapes, from smaller than a postage stamp to several inches across. They are often connected together to form PV modules that may be up to several feet long and a few feet wide.

Modules, in turn, can be combined and connected to form PV arrays of different sizes and power output. The modules of the array make up the major part of a PV system, which can also include electrical connections, mounting hardware, power-conditioning equipment, and batteries that store solar energy for use when the sun is not shining.

When light shines on a PV cell, it may be reflected, absorbed, or pass right through. But only the absorbed light generates electricity. The energy of the absorbed light is transferred to electrons in the atoms of the PV cell semiconductor material. With their newfound energy, these electrons escape from their normal positions in the atoms and become part of the electrical flow, or current, in an electrical circuit. A special electrical property of the PV cell—what is called a "built-in electric field"—provides the force, or voltage, needed to drive the current through an external load, such as a light bulb.

Crystalline silicon PV cells are the most common photovoltaic cells in use today. They are also the earliest successful PV devices. Therefore, crystalline silicon solar cells provide a good example of typical PV cell functionality.

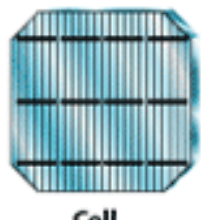

Cell

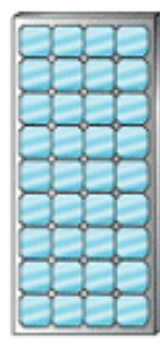

Module

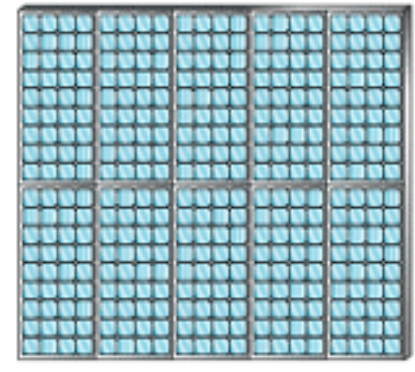

Array 
Potential resources. Resources, either supply-side or demand-side, which are either currently commercially available, feasible, or are expected to be commercially available within the planning period.

Power. The rate at which energy is being generated or used over time, measured in units such as joules/second or British thermal units/hour. Electrical power and electrical energy are often confused because of the way their units of measurement are expressed. Because electrical power is measured in watts, which is actually a rate ( 1 watt $=1$ Joule/second $)$, electrical energy is watts multiplied by time (e.g., watt-seconds $[1 \mathrm{Ws}=1$ Joule] or kilowatt-hours).

Present value. The value of a cost or stream of yearly costs that have been discounted to reflect the fact that future benefits or expenditures are worth less than current benefits or expenditures. Also called present worth. See: discount rate.

Pumped storage hydroelectric plant. An electric generation facility consisting of a higher reservoir, a lower reservoir, pipes connecting the two reservoirs, and turbine-generator units that can be reversed to become pumps. At times when electricity demand is low, base load generating plants provide electricity to pump water from the lower reservoir to the higher. During peak demand periods, water is released from the higher reservoir, spins the turbine-generator units to generate electricity, and is expelled to the lower reservoir.

Ratepayer impact test. An analytic test that includes the costs and benefits from the perspective of a nonparticipating consumer. In effect, this test examines the price impacts of demand-side management programs.

Real levelized cost. The uniform cost of electricity, in constant dollars, for which the present value of the electricity produced equals the present value of the costs of the plant.

Real monetary values. Expression of the value of dollars or other currency units over several years, using the value in one specified year as the baseline, and for other years removing the effects of price inflation relative to that baseline year. This facilitates analysis of the economic advantages and disadvantages of different alternatives that occur in different time periods.

Reserve margin. The difference between an electric system's maximum capacity and the expected peak demand. Planning reserve margins are based on explicit reliability criteria.

Revenue requirements. The amount of revenues that a utility needs to receive in order to cover operating expenses, pay debt service, and provide a fair return to common equity investors.

Saturation (of energy-using equipment). The ratio of the number of specific types of appliances or equipment to the total number of customers in that class or to the total number of appliances or equipment in use (e.g., the fraction of existing homes with double-pane windows).

Social discount rate. A discount rate that reflects the rate of time preference for evaluating investments from the perspective of society. In the United States, for example, the rate for U.S. government treasury bonds, for a time period equal to the IRP planning period, may be used to represent this discount rate.

Societal cost test. An analytic test that evaluates all of the costs and benefits to society associated with a specific resource. A resource option is cost-effective under this test when the present value of benefits over the planning period exceeds the present value of costs, using an appropriate social discount rate. This is essentially the total resource cost test with the maximum feasible monetization of externalities (positive and negative). 
Solar thermal energy. Solar thermal energy is solar energy in the form of heat and light, harnessed as heat. Solar thermal energy is different from photovoltaics, which convert solar energy directly into electricity. Solar thermal collectors are classified by the United States Energy Information Administration as low-, medium-, or high-temperature collectors. Low-temperature collectors are flat plates generally used to heat swimming pools. Medium-temperature collectors are also usually flat plates but are used for heating water or air for residential and commercial use. High-temperature collectors (concentrated solar power or CSP) concentrate sunlight using mirrors or lenses and are generally used for electric power production.

Common solar thermal energy designs include:

- Solar water heating (SWH; also referred to as solar hot water): Solar water heating systems include storage tanks and solar collectors. There are two types of solar water heating systems: active, which have circulating pumps and controls, and passive, which do not. Direct circulation systems are active systems that have pumps that circulate household water through the collectors and into the home. They work well in climates where it rarely freezes. Indirect circulation systems are inactive and have pumps that circulate a non-freezing, heat-transfer fluid through the collectors and a heat exchanger. This heats the water that then flows into the home. They are popular in climates prone to freezing temperatures. Passive solar water heating systems are typically less expensive than active systems, but they're usually not as efficient. However, passive systems can be more reliable and may last longer. There are two basic types of passive systems. One type is integral collector-storage passive systems that work best in areas where temperatures rarely fall below freezing; they also work well in households with significant daytime and evening hot-water needs. The other type is thermosyphon systems. In a thermosyphon system water flows through the system when warm water rises and cooler water sinks. The collector must be installed below the storage tank so that warm water will rise into the tank. These systems are reliable, but contractors must pay careful attention to the roof design because of the heavy storage tank. They are usually more expensive than integral collectorstorage passive systems.

- Parabolic trough-designed solar collectors: Curved, mirrored troughs that reflect the direct solar radiation onto a glass tube containing a fluid - also called a receiver, absorber, or collectorrunning the length of the trough, positioned at the focal point of the reflectors. The hot fluid is piped to equipment, such as a heat engine, which uses its energy for some purpose, such as generating electricity.

- Solar power towers (also known as 'central tower' or 'heliostat' power plants): Capture and focus the sun's thermal energy with thousands of tracking mirrors (called heliostats). A tower resides in the center of the heliostat field. The heliostats focus concentrated sunlight on a receiver that sits on top of the tower. Within the receiver, the concentrated sunlight heats molten salt to over $1,000^{\circ} \mathrm{F}\left(538^{\circ} \mathrm{C}\right)$. The heated molten salt then flows into a thermal storage tank where it is stored and eventually pumped to a steam generator. The steam drives a standard turbine to generate electricity. This process, also known as the "Rankine cycle," is similar to a standard coal-fired power plant, except it is fueled by clean and free solar energy.

- Dish designs: Uses a large, reflective, parabolic dish (similar in shape to satellite television dish) to focus all the sunlight that strikes the dish up onto a single point above the dish, where a receiver captures the heat and transforms it into a useful form.

Strategic load growth. The increase of end-use consumption during certain periods. The result is a general increase in energy sales beyond the valley filling (defined herein) strategy. Strategic load growth 
may involve increased market share of loads that are, or can be, served by competing fuels, as well as economic growth.

Supply-only plan. The plan, using only supply-side resources, which a utility believes will best enable it to provide reliable service at minimum reasonable total resource costs over the planning period.

Supply-side management. Refers to the practice of electric utilities building generating plants to serve whatever demand customers require. This practice was the norm until the 1970s.

Supply-side resource. A resource option that produces electricity.

Surplus energy. Generated electricity that is beyond the needs of the service area of an electric system.

Technical potential. An estimate of electric savings assuming existing appliances, equipment, buildingshell measures, and industrial processes will be replaced with the most efficient commercially available measures, regardless of economic cost or achievability.

Time of use rates or pricing (TOU rates or TOU pricing). Electricity prices are set for a specific time period on an advanced or forward basis, typically not changing more often than twice a year. Prices paid for energy consumed during these periods are pre-established and known to consumers in advance, allowing them to vary their usage in response to such prices and manage their energy costs by shifting usage to a lower cost period or reducing their consumption overall. It is an electric rate program designed to reward customers for shifting their electric usage away from times of peak customer demand.

Total resource cost (TRC) test. An analytic test that evaluates all of the direct costs and benefits to society associated with a specific resource. A resource option is cost-effective under this test when the present value of benefits over the planning period exceeds the present value of costs, using an appropriate social discount rate. This test does not assess the distribution of costs and benefits among the utility and subsets of customers.

Transmission. Transmission lines carry electricity from power plants to areas where electricity is needed. Electricity travels at nearly the speed of light, arriving at a destination at almost the same moment it is produced. Reliable electric service and regional electricity markets depend on strong transmission systems. Typical transmission line voltage differs depending on the structure. Transmission lines carry high voltage electricity, typically at 345,000 volts, over long distances between the power generation plant and customers. In some cases, a large industrial customer may receive electricity directly from overhead transmission lines. Transmission line voltage is lowered and fed to subtransmission lines at 69,000 volts. These lines normally supply large commercial businesses. Voltage of sub-transmission lines is decreased to feed the majority of business, small industrial, and residential customers. The voltage of a local transmission line is 13,800 volts. This voltage is then lowered even further to between 220 and 440 volts for industrial use, and to 120 and 240 volts for commercial and residential customers.

Utility discount rate. A rate that reflects the utility's weighted cost of capital. Pre-tax, or more commonly, after tax.

Utility revenue requirements test. An analytic test that includes the costs and benefits from the perspective of a utility. The costs are the utility's costs of administering and delivering demand-side management (excluding participant contributions). The benefits are the utility's avoided supply costs. The test does not measure the financial impact of demand-side management on a utility corporation. 
Valley filling. The building of off peak loads. An example valley filling technology is thermal storage (water heating and/or space heating or cooling) that increases night time loads and reduces peak period loads. Valley filling may be desired in periods when the long-run incremental cost of supply is less than the average price of electricity (adding off-peak load under those circumstances decreases the average price).

Variable operation and maintenance $(\mathrm{O \& M})$ costs. The additional cost per kilowatt-hour of electricity produced that goes toward operation and maintenance of the plant. These costs vary with the output of the plant, and are expressed in cents per kilowatt-hour of electricity produced.

Volts (V). The International System of Units (SI) measurement of electric potential. Separating electric charges creates potential energy. Electric potential is defined as the amount of potential energy present per unit of charge. Electric potential is measured in volts, with one volt representing a potential of one joule per coulomb of charge. The name of the unit honors the Italian scientist Count Alessandro Volta (1745-1827), the inventor of the first battery.

Watt (W). The electrical unit of power or rate of doing work. A light bulb rated at $100 \mathrm{~W}$ requires 100 $\mathrm{W}$ of power to light it fully.

Watt-hour. The total amount of energy used in one hour by a device that requires one watt of power for continuous operation. Electric energy is commonly sold by the kilowatt-hour (1000 watts).

Watt peak $\left(\mathbf{W}_{\mathbf{p}}\right)$. Maximum power output of a 1 square meter solar panel at 25 degrees centigrade. This unit of output is devised to compare the performances of various types and makes of solar panels. A 100 Wp panel is supposed to produce 100 watts. In real life, a solar panel produces less.

Waste-to-energy (WTE). Waste-to-Energy technologies consist of various methods for extracting energy from waste materials. These methods include thermochemical and biological methods. The only WTE technology that is commercially available in the United States using municipal solid waste (MSW) feedstock is combustion. All other processes hold high potential for utilizing MSW feedstock but must overcome various technical or procedural challenges before they are commercially viable. The primary challenge facing these technologies is the heterogeneous nature of MSW, which creates a widely varying chemical constituency of the energy products generated from these processes. Most WTE processes produce electricity directly through combustion, or produce a combustible fuel commodity, such as methane, methanol, ethanol, or synthetic fuels.

WTE anaerobic digestion. Anaerobic digestion is a process where microorganisms break down organic materials, such as food scraps, manure, and sewage sludge, in the absence of oxygen. Anaerobic digestion produces biogas and a solid residual. Biogas, made primarily of methane and carbon dioxide, can be used as a source of energy similar to natural gas. The solid residual can be land applied or composted and used as a soil amendment. The benefits of anaerobic digestion include renewable energy generation, greenhouse gas emissions reduction, and waste diversion.

WTE landfill gas (LFG). LFG is created when organic waste in a municipal solid waste landfill decomposes. This gas consists of about $50 \%$ methane (the primary component of natural gas), about $50 \%$ carbon dioxide, and a small amount of non-methane organic compounds. Instead of being allowed to escape into the air, LFG can be captured, converted, and used as an energy source. Using LFG helps to reduce odors and other hazards associated with LFG emissions, and helps prevent methane from migrating into the atmosphere and contributing to local smog and global climate change.

Waste-to-energy combustion. The controlled burning of solid waste at extremely high temperaturesoften as high as $2,000^{\circ} \mathrm{F}$. Combustion of all types currently accounts for $14 \%$ of solid waste disposal in the United States. The U.S. Environmental Protection Agency estimated that $23 \%$ of the municipal solid 
waste stream will be disposed of via combustion by 1995 . Waste-to-energy combustion is widely used in Japan, some parts of Europe, and elsewhere to reduce by as much as $80 \%$ to $90 \%$ the volume of waste that must be landfilled. Waste-to-energy combustion should not be confused with simple open burning of refuse. It is even different from mass-burn waste combustion common in the United States in the first half of the $20^{\text {th }}$ century. In waste-to-energy combustion, the heat generated by the process is captured and turned into usable energy. The energy produced can be used either in the form of steam or in the form of electricity produced by steam turbine generators.

WTE gasification. Gasification converts carbon-containing materials, under high temperature and pressure, into synthesis gas. Synthesis gas or syngas is generally composed of hydrogen and carbon monoxide but can be manufactured to contain methane and other higher molecular weight compounds. Syngas can be used as a fuel to generate electricity or as a basic chemical building block for use in the petrochemical and refining industries. Syngas generally has a heating value that is approximately twothirds that of natural gas and, when burned as fuel, produces emissions that are similar to natural gas. In the petroleum-refining industry alone, about seven to ten million tons per year of hazardous byproducts containing carbon could be converted into useable fuel or chemicals using gasification methods. 
NATIONAL RENEWABLE ENERGY LABORATORY — LEADING CLEAN ENERGY INNOVATION

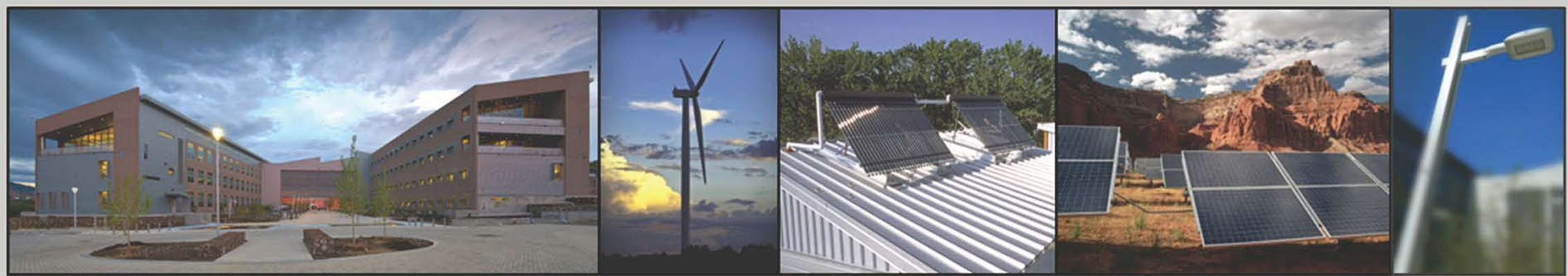

Prepared by the National Renewable Energy Laboratory (NREL), a national laboratory of the U.S. Department of Energy, Office of Energy Efficiency and Renewable Energy, operated by the Alliance for Sustainable Energy, LLC. NREL is the U.S. Department of Energy's primary laboratory for renewable energy and energy efficiency research and development.

15013 Denver West Parkway, Golden, CO 80401 • 303-275-3000 • www.nrel.gov 